\title{
Analysis of Heterogeneous Concepts during Projection of Facilities of Good Manufacturing Practice and Human Biobank
}

\author{
Ivo Spiroski
}

Faculty of Design and Technologies of Furniture and Interior, Ss Cyril and Methodius University of Skopje, Skopje, Republic of Macedonia

Citation: Spiroski I. [Analysis of Heterogeneous Concepts during Projection of Facilities of Good Manufacturing Practice during Projection of Facilities of Good Manufacturing Practice
and Human Biobank]. SEE J Archit Des. 2015 Jan 23 2015:10001.
http://dx.doi.org/10.3889/seejad.2015.10001

Key words: Incision; urban fragments; city-mosaic; housing: connection; bridge; transformation; communication

"Correspondence: MSc Eng Ivo Spiroski. ID Design mail: ispiroski@id-press.eu

Received: 14-Dec-2014; Revised: 21-Dec-2014; Accepted: Received: 14-Dec-2014; Revised: 21 -Jan-2015; Published: 23-Jan-2015

Copyright: $\odot 2015$ Ivo Spiroski. This is an open-access article distributed under the terms of the Creative Commons distribution and reproduction in any medium, provided the original author and source are credited.

Competing Interests: The author have declared that no competing interests exis.

\section{Abstract}

AIM: The aim of this thesis is to analyse and to present heterogeneous concepts during projection of facilities of good manufacturing practice and human biobank.

MATERIAL AND METHODS: Feasibility study for bio banks of stem cells is prepared for one current health institution in Republic of Macedonia.

RESULTS: The space covers 105 square meters for biobank for stem cells, as well as additional space. With this projects program are defined requested needs of the investor during preparation of the basic project for the biobank for stem cells. The prepared architectural constructive solution allow smooth flow of the technology defined by the investor. The solution is optimal related to the function, construction and economics.

CONCLUSION: It was established that in the Republic of Macedonia there is not present any kind of bank for stem cells, but there are present several liaison offices for collection and deposition of stem cells from several foreign countries. It is necessary to project, construct and to put in function several banks for stem cells in the Republic of Macedonia in order to fulfil the needs of patients with malignant diseases. 


\begin{abstract}
Република Македонија
Универзитет „Св. Кирил и Методиј“ во Скопје,

Факултет за дизајн и технологии на мебел и ентериер -

Скопје
\end{abstract}

\title{
АНАЛИЗА НА ХЕТЕРОГЕНИТЕ КОНЦЕПТИ ПРИ ПРОЕКТИРАҢЕ НА ПРОСТОРИ ЗА ДОБРА ПРОИЗВОДНА ПРАКСА И ХУМАНА БИОБАНКА
}

- магистерски труд - 
Ментор: Доц. Д-р Елена Никољски Паневски

ФАКУЛТЕТ ЗА ДИЗАЈН И ТЕХНОЛОГИИ НА МЕБЕЛ И ЕНТЕРИЕР - СКОПЈЈ

Студиска програма: Проектирање на мебел и ентериер 


\section{БЛАГОДАРНОСТ}

Магистерскиот труд е изработен на Катедрата за проектирање на мебел и ентериер, при Факултет за дизајн и технологии на мебел и ентериер - Скопје, Универзитет „Св. Кирил и Методиј” во Скопје.

Најголема благодарност му искажувам на мојот ментор проф. д-р Елена Никољски Паневски која ми помогна во изборот на темата, изработката на трудот, структурирањето и содржината на текстот. Професор Никољски со својата стручност го овозможи завршувањето на магистерскиот труд.

Особена благодараност им должам на проф. д-р Борче Илиев и проф. д-р Владимир Каранаков кои со своите совети и поддршка во целокупниот период на изработка на овој магистерски труд значително го подобрија квалитетот.

Му искажувам благодарност на дипл. инж. арх. Александар Петановски кој ми помогна во изработката на техничките цртежи.

Им благодарам на моето семејство за несебичната подршка и огромното разбирање во текот на изработката на овој магистериум. 


\section{СОДРЖИНА}

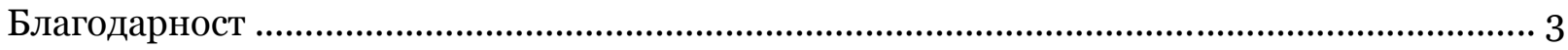

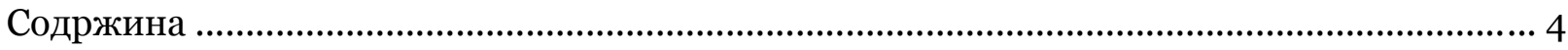

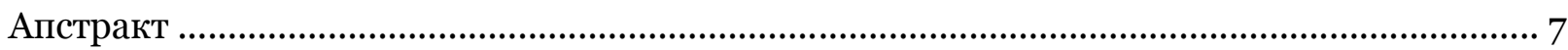

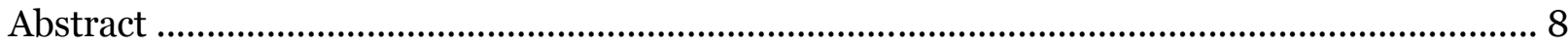

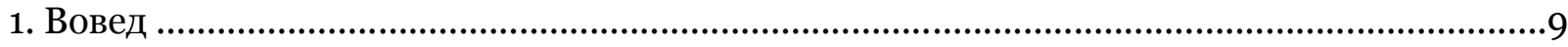

2. Методологија на истражување ..................................................................................... 10

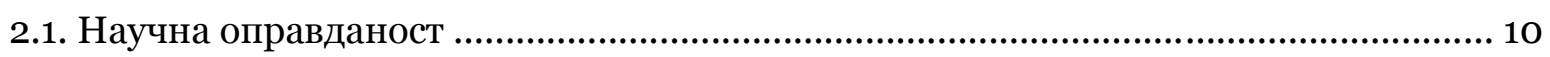

2.2. Предмет и цели на научно истражување .............................................................. 10

2.3. Методи на научното истражување ............................................................................ 10

3. Еволуција на најдобрите практики за биобанки ...................................................... 12

3.1. Технички стандарди ............................................................................................. 13

3.2. Медицински стандарди за собирање, процесирање и складирање ....................... 14

3.3. Општествено - економски стандарди за менаџирање со биобанки ...................... 15

3.4. Информатички практики за биобанки ................................................................... 15

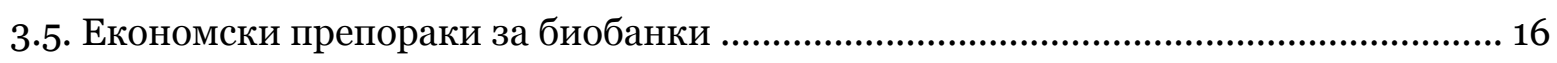

3.6. Обезбедување квалитет на биобанки ...................................................................... 17

3.7. Специфики при проектирање на просторот за биобанки ....................................... 18

3.7.1. Примена на чиста соба ….......................................................................................... 18

3.8. Класификација на чисти соби и опрема за чист воздух ………............................ 20

4. Стратешко планирање и намена на просторот за банка на матични клетки ................. 21

4.1. Функционален аспект на проектната анализа ..................................................... 22

4.2. Техничко - конструктивен аспект на проектната анализа ...................................... 23

4.3. Физибилити студија за намената на објектот …........................................................ 24

5. Организација на проектот ............................................................................................. 26

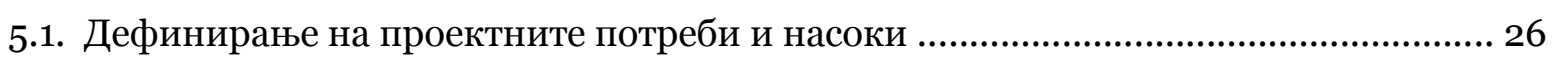

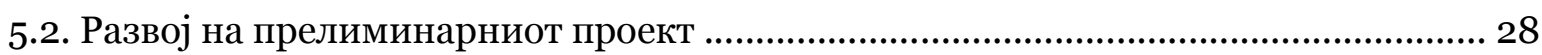

5.3. Условености кои призлегуваат од проектот на објектот ……................................... 33

6. Анализа на елементите на ентериерот …….................................................................... 38 
6.1. Анализа на дизајнот на мебел по проект за дадениот простор ……....................... 38

6.1.1. Просторија за складирање на матични клетки ...................................................... 38

6.1.2. Просторија за изолација на матични клетки .................................................... 41

6.1.3 Просторија за земање на примероци од крв ......................................................... 44

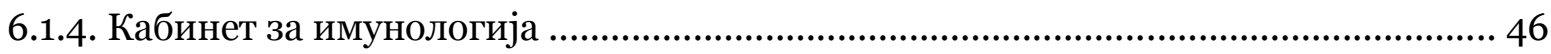

6.1.5. Кабинет за молекуларна медицина ….................................................................... 47

6.1.6. Кабинет за хумана генетика …............................................................................ 49

6.1.7. Лабораторија за молекуларна имунологија ….................................................. 51

6.1.8. Лабораторија за протеини и аутоантитела …….................................................. 52

6.1.9. Лабораторија за алергологија и серолошка имуногенетика..................................5 54

6.1.10. Лабораторија за проточна цитометрија …........................................................ 56

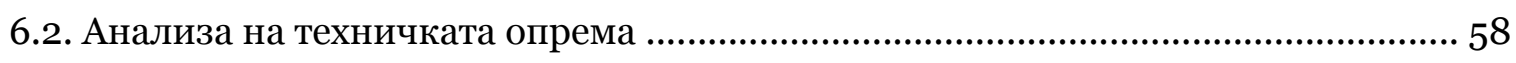

6.2.1. Опремување на просторот за биобанка ……........................................................ 58

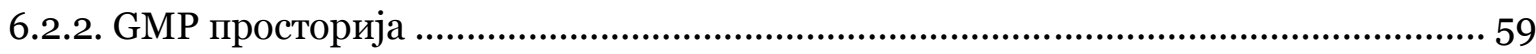

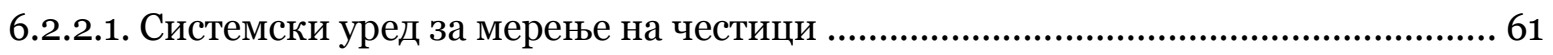

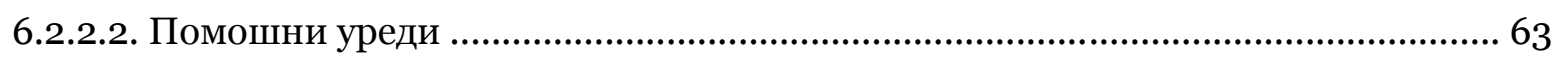

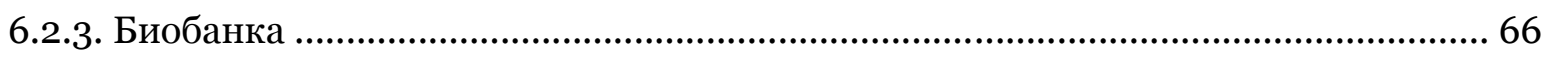

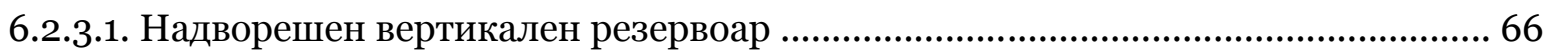

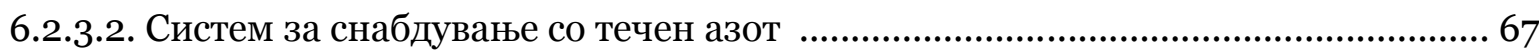

6.2.3.3. Криобиолошки контејнери (Деварови садови) ............................................... 68

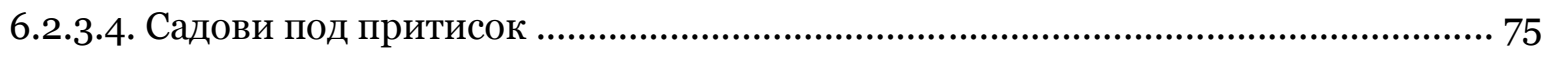

6.2.3.5. Систем за надзор ......................................................................................... 76

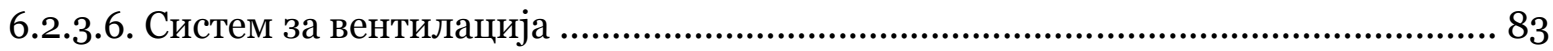

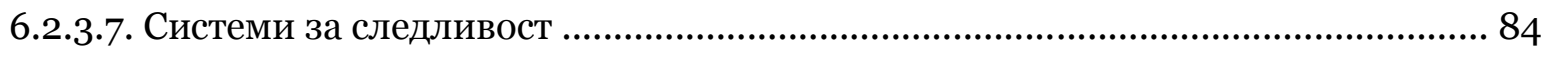

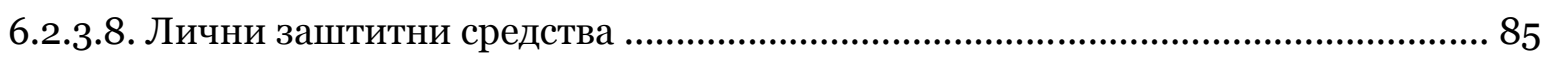

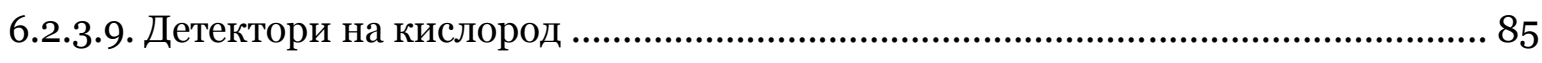

6.2.3.10. Машина за затворање на кеси за крв од папочна врвца …............................ 87

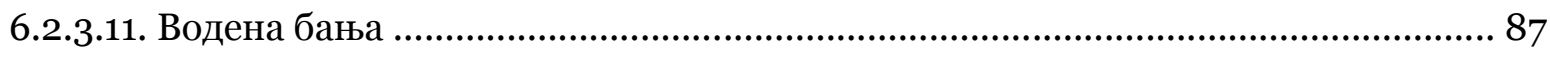


6.2.3.12. Вакумска пумпа ValuPump за отстранување DMSO ........................................ 88

6.2.3.13. Лабораториски уреди за проточна цитометрија .............................................. 88

6.2.3.14. Лабораториски уреди за молекуларна генетика .............................................. 90

6.3. Анализа на проектот за преградни, монтажно - демонтажни sидови .................. 92

6.4. Анализа на вештачкото осветлување и таваниците во просторот........................... 92

6.4.1. Таванско решение и осветлување на просторот за банка за матични клетки.... 95

6.4.2. Таванско решение и осветлување на приземјето................................................ 96

6.4.3. Таванско решение и осветлување на првиот кат ................................................ 97

6.5. Анализа на природното осветлување на лабораториите и кабинетите............... 98

6.6. Анализа на физичките карактеристики на просторот ........................................ 99

6.6.1. Акустика …........................................................................................................... 99

6.6.2. Загревање и ладење на објектот ……............................................................... 100

6.6.2.1. Загревање и ладење на банката за матични клетки .......................................100

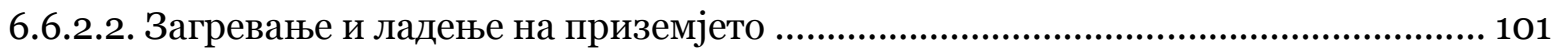

6.6.2.3. Загревање и ладење на првиот кат ................................................................... 102

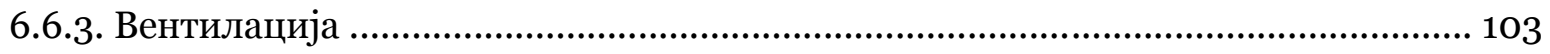

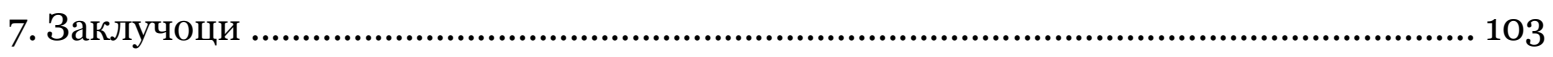

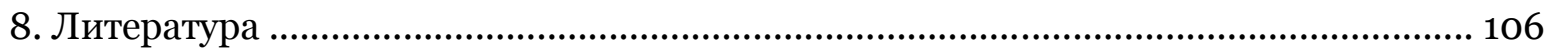




\section{Апстракт}

\section{Иво Спироски}

\section{Анализа на хетерогените концепти при проектирање на простори за добра производна пракса и хумана биобанка}

Целта на оваа теза е да ги анализира и да ги прикаже хетерогените концепти при проектирање на простори за добра производна пракса и хумана биобанка.

Идејниот проект за биобанка за матични клетки е подготвен за една постојна здравствена установа во Република Македонија. Просторот опфаќа стоипет квадратни метри за биобанка на матични клетки, како и додатен простор за комуникација како: лифт, скали, хидростаница, санитарии и комуникација.

Со оваа проектна програма се дефинирани барањата и потребите на инвеститорот при изработката на Основниот проект на Банка за матични клетки. Изработеното архитектонско - градежно решение овозможува непречено одвивање на технолошките процеси посочени од инвеститорот. Решението е оптимално во однос на функција, конструкција и економичност. Основниот проект - архитектура за банка за матични клетки е изготвен со почитување на сите градежно - техничките прописи и нормативи кои се однесуваат за објекти од образование и наука за да може врз база на истиот да се добие дозвола за градба.

Се констатира дека во Република Македонија не постои ниту еден облик на Банка за матични клетки, туку дека постојат повеќе претставништва за земање и складирање матични клетки од неколку странски земји. Со оглед на овој факт упатно би било да се проектираат, изградат и да функционираат една или повеќе Банки за матични клетки во Република Македонија за да се покријат потребите од матични клетки за пациентите со малигни заболувања.

Клучни зборови: Хетерогени концепти на проектирање; банка за матични клетки; добра производна пракса; хумана биобанка. 
Abstract

\section{Ivo Spiroski}

\section{Analysis of heterogeneous concepts during projection of facilities of good manufacturing practice and human biobank}

The aim of this thesis is to analyse and to present heterogeneous concepts during projection of facilities of good manufacturing practice and human biobank.

Feasibility study for bio banks of stem cells is prepared for one current health institution in Republic of Macedonia. The space covers 105 square meters for biobank for stem cells, as well as additional space for lift, ladders, hydro station, toilets, and communication.

With this projects program are defined requested needs of the investor during preparation of the basic project for the biobank for stem cells. The prepared architectural - constructive solution allow smooth flow of the technology defined by the investor. The solution is optimal related to the function, construction and economics. The basic project - architecture for biobank for stem cells is constructed following all constructive - technical guidelines and standards applied for the buildings in education and science in order to be accepted for construction.

It was established that in the Republic of Macedonia there is not present any kind of bank for stem cells, but there are present several liaison offices for collection and deposition of stem cells from several foreign countries. It is necessary to project, construct and to put in function several banks for stem cells in the Republic of Macedonia in order to fulfil the needs of patients with malignant diseases.

Key words: Heterogenous concepts of projecting; bank for stem cells; good manufacturing praxis of biobank; human biobank. 


\section{1. Вовед}

Анализирајќи ги досегашните состојби во Република Македонија во доменот на здравството и здравствените организации, констатирано е дека простори за добра производна пракса и хумана биобанка не постојат. Секојдневната потреба за создавање на различни видови хумани биобанки бара анализа на хетерогените концепти и нивна конкретна примена.

Во овој труд ќе биде прикажана еволуцијата на најдобрата практика за биобанки, техничките и медицинските стандарди за собирање, процесирање и складирање како и општествено - економските стандарди за менаџирање со биобанки.

Посебно ќе бидат анализирани информатичките практики, економските препораки, како и обезбедувањето квалитет на биобанките. Проектирањето на просторот за биобанки бара определени специфики кои може да се опишат со примената на чиста соба.

Во методологијата на истражувањето ќе биде анализирана научната оправданост, предметот и целите како и методите за научно истражување. Намената на просторот за банка за матични клетки ќе биде анализирана од функционален и техничко-конструктивен аспект како и физибилити студија за намена на објектот.

Во организација на проектот ќе бидат прикажани проектните потреби и насоки, развој на прелиминарниот проект како и условеностите кои произлегуваат од проектот на објектот. Елементите од ентериерот ќе бидат анализирани за мебел изработен по проект за даден простор на банка за матични клетки, опремувањето со мебел, анализата на мобилни преградни и монтажно-демонтажни sидови, системско решавање на вештачкото осветлување и таваниците на просторот, применетото природно осветлување на просторот за лаборатории и кабинети, како и анализа на физичките карактеристики на просторот. 


\section{2. Методологија на истражување}

\section{1. Научна оправданост}

Складирањето матични клетки претставува значаен дел од лекувањето на најтешките болести во светот, како што се леукемиите кај деца и возрасни, оштетување на коскената срцевина и други малигни заболувања. Поради тоа се создаваат банки за матични клетки кој се користат за лекување на овие болести.

\section{2. Предмет и цели на научно истражување}

Главна цел на овој магистерски труд е да ги проучи меѓународните стандарди за најдобра пракса за создавање различни типови биобанки и да се проучат инфраструктурните потреби, особено внатрешниот дизајн, за секој вид биобанка.

Дополнителна цел е да се проучат специфичните материјали и опрема неоходни за функционирање на различните видови биобанки.

Специфична цел на овој магистерски труд е изработка на идејно решение за биобанка на матични клетки во некоја медицинска установа во Република Македонија, како пример за специфичен вид инфраструктура на биобанка во Република Македонија.

\section{3. Методи на научното истражување}

Европската Унија усвои упатства за добра производна пракса во која се дефинирани условите за производство на стерилни продукти ${ }^{1}$. Во ова упатство не се дадени деталите за определување микробиолошка чистота и чистота на честиците во воздухот, на површините и слично. Овие стандарди се дадени во други документи, кои ќе бидат споменати подолу.

Во конкретната студија за проектирање и реализација на простор за добра производна пракса и биобанка на една јавна здравствена установа ќе биде изработена врз основа на податоците добиени при консултација со инвеститорот. Во студијата ќ бидат опфатени дизајн и реализација на просторот наменет за манипулација и складирање на биолошки примероци, дефинирани како:

- GMP (Good Manufacturing Practice) просторија, односно просторија за добра производна пракса;

- просторија за биобанка;

\footnotetext{
$1 \quad$ EudraLex. The Rules Governing Medicinal Products in the European Union. Volume 4. EU Guidelines to Good Manufacturing Medicinal Products for Human and Veterinary Use. EUROPEAN COMMISSION ENTERPRISE AND INDUSTRY DIRECTORATE-GENERAL: Brussels, 25 November 2008.
} 
- просторија за земање примероци крв;

- просторија за обработка на примероците (изолирање на ДНК);

- лабораторија за определување генетската структура за примероците (ХЛА-ДНК типизација).

Првите две простории (1 и 2) се сместени во подрумот на зградата, другите две простории (3 и 4) се сместени во приземје на зградата, а петтата просторија е сместена на првиот кат.

Решението опфаќа архитектонско - градежен дизајн а избраниот простор, опремување на просториите.

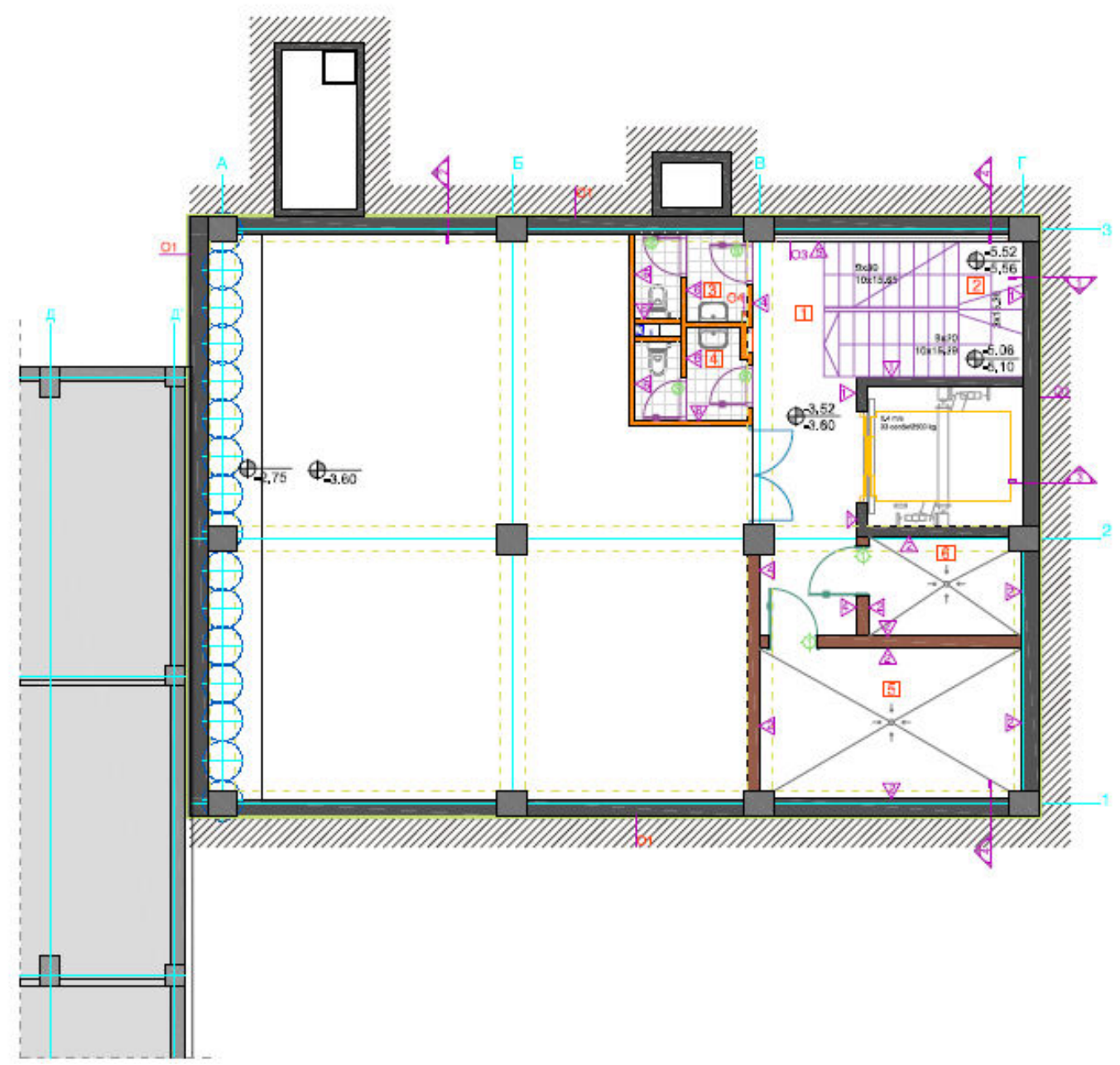

Слика 1: Архитектонска подлога за идеен проект на ентериер од банка за матични клетки 


\section{3. Еволуција на најдобрите практики за биобанки}

Секоја година милиони биолошки примероци се собираат за различни цели, вклучувајки основни научни истражувања, клинички студии и епидемиолошки студии ${ }^{2}$ Биолошките примероци се складираат во биобанки, кои што може исто така да се наречат биоскладишта (биорепозитори), ресурси за биолошки примероци или центри за биолошки примероци, кои се користат за идни анализи. Во клиничката лабораторија складирањето крв и урина од пациенти е основа за многу испитувања и анализи ${ }^{3}$ Смрзнати или ткива фиксирани со формалин исто така се собираат во клинички услови како за дијагностицирање така и за научни истражувања4. Стандардните оперативни процедури, референтните стандарди и контрола на квалитетот беа основни предуслови за клиничките лаборатории многу години порано. За клиничките испитувања беа утврдени прецизни правила меѓутоа за биолошките примероци собирани за научни истражувања не беа толку прецизни.

Првите банки за матични клетки и најчестите во светот се банки на матични клетки од папочната врвца. Во светот се развија банки на матични клетки за семејна употреба и јавно достапни банки за матични клетки.

Банките за матични клетки за семејна употреба се приватни банки во кои семејството складира крв од папочната врвца или изолирани матични клетки кои би можеле потенцијално да бидат употребени за некој од членовите на потесното семејство.

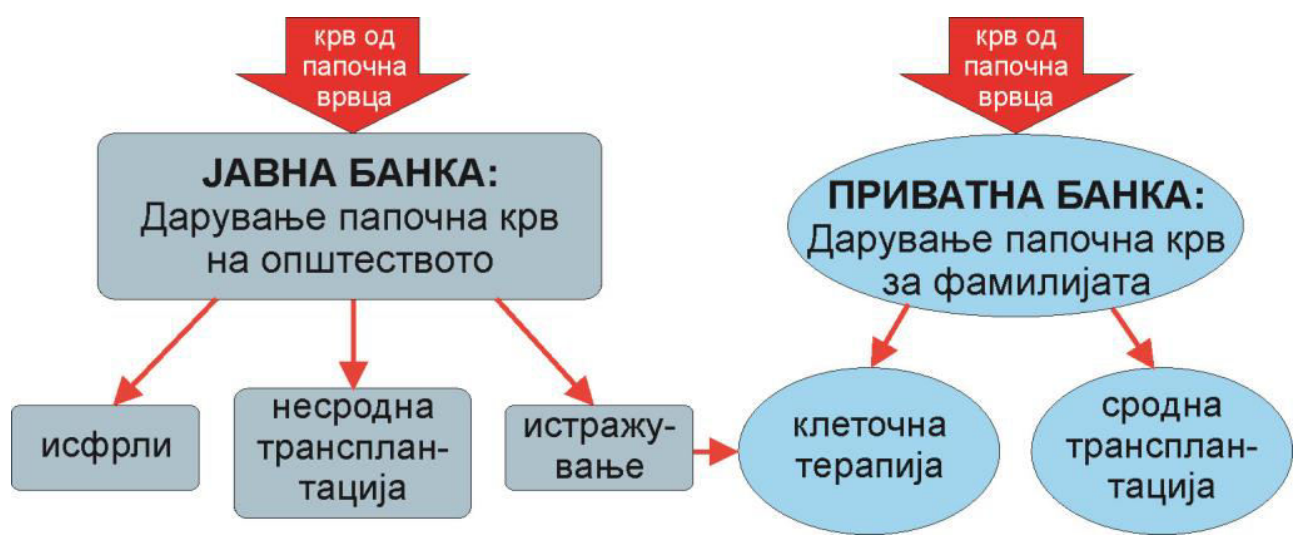

Графикон 1: Дарување папочна крв во јавна и во приватна банка

\footnotetext{
2 Eiseman E, Haga SB, editors. Handbook of human tissue sources: a national resource of human tissue samples. Santa Monica, CA: RAND Corporation; 1999.

3 Riegman PH, Dinjens WN, Oosterhuis JW. Biobanking for interdisciplinary clinical research. Pathobiology 2007;74:239-44.

$4 \quad$ Hughes S, Barnes RO, Watson PH. Biospecimen use in cancer research over two decades. Biopreserv Biobanking 2010;8:89-97.
} 
Јавно достапните банки ги финансираат државните институции или фондации во кои брачните парови со потпишана согласност ја даруваат крвта од папочната врвца од која се изолираат и складираат матични клетки и се употребуваат за било кого, доколку е пациентот генетски идентичен.

Во ретки случаи примероците од складираните матични клетки на семејството од семејните банки за матични клетки може подоцна да ги подарат во јавните банки за матични клетки и да бидат употребени за пациенти надвор од нивното семејство. Најчесто ова се изведува со соодветен материјален надомест. Бидејки семејството плаќа за складирањето на матични клетки а во јавните банки, пациентите не плаќаат туку трошоците ги покрива државата.

Последниве години голем број организации развија и објавија серија од најдобри практики со кои се регулираат принципите за складирање биолошки примероци 5 . Овие документи ги покриваат техничките аспекти на биолошките примероци, како што се собирање, процесирање, складирање, обезбедување, квалитет, информациски системи за собирање податоци, како и етички регулаторни прашања како што се информираната согласност, приватноста на пациентите и интелектуалната сопственост.

\section{1. Технички стандарди}

Техничките најдобри практики вклучуваат препораки за „основите“ на биобанките: собирање, процесирање, складирање и распоредување на биолошките примероци, како и соодветните податоци од собирањата и управување. Од неодамна се појави ново поле во науката за биолошки примероци кое се обидува да развие најдобри практики засновани на докази и стандардни оперативни процедуриб. Од кога истражувањето за биолошки примероци се разви како поле, стана се повидливо во равојот на најдобрите практики засновано врз доказите од литературата. На пример, се собраа докази дека должината на времето помеѓу собирањето крв или ткива може да влијае врз крајниот резултат7. Повеќекратното одмрзнување и замрзнување на примероци од крв, може исто така штетно

$5 \quad$ Vaught J, Caboux E, Hainaut P. International efforts to develop biospecimen best practices. Cancer Epidemiol Biomarkers Prev 2010;19:912-5.

6 Moore HM, Compton CC, Alper J, Vaught JB. International approaches to advancing biospecimen science. Cancer Epidemiol Biomarkers Prev 2011;20:729-32.

$7 \quad$ Hatzis C, Sun H, Yao H, Hubbard RE, Meric-Bernstam F, Babiera YW, et al. Perioperative ischemia and tissue preservation effects on RNA integ239rity and microarrays of breast cancer. J Natl Cancer Inst 2011;103:187183. 
да влијае на определени аналитички процедури, иако за нуклеинските киселини, некои хормони и микроелементи, овие ефекти се минимални ${ }^{8}$.

\section{2. Медицински стандарди за собирање, процесирање и складирање}

Примери од варијабли кои треба да бидат земени во предвид се:

- собирање крв - епрувети за собирање во кои има етилендиамин тертраоцетна киселина (ЕДТА) или хепарин, можат да влијаат на анализата9;

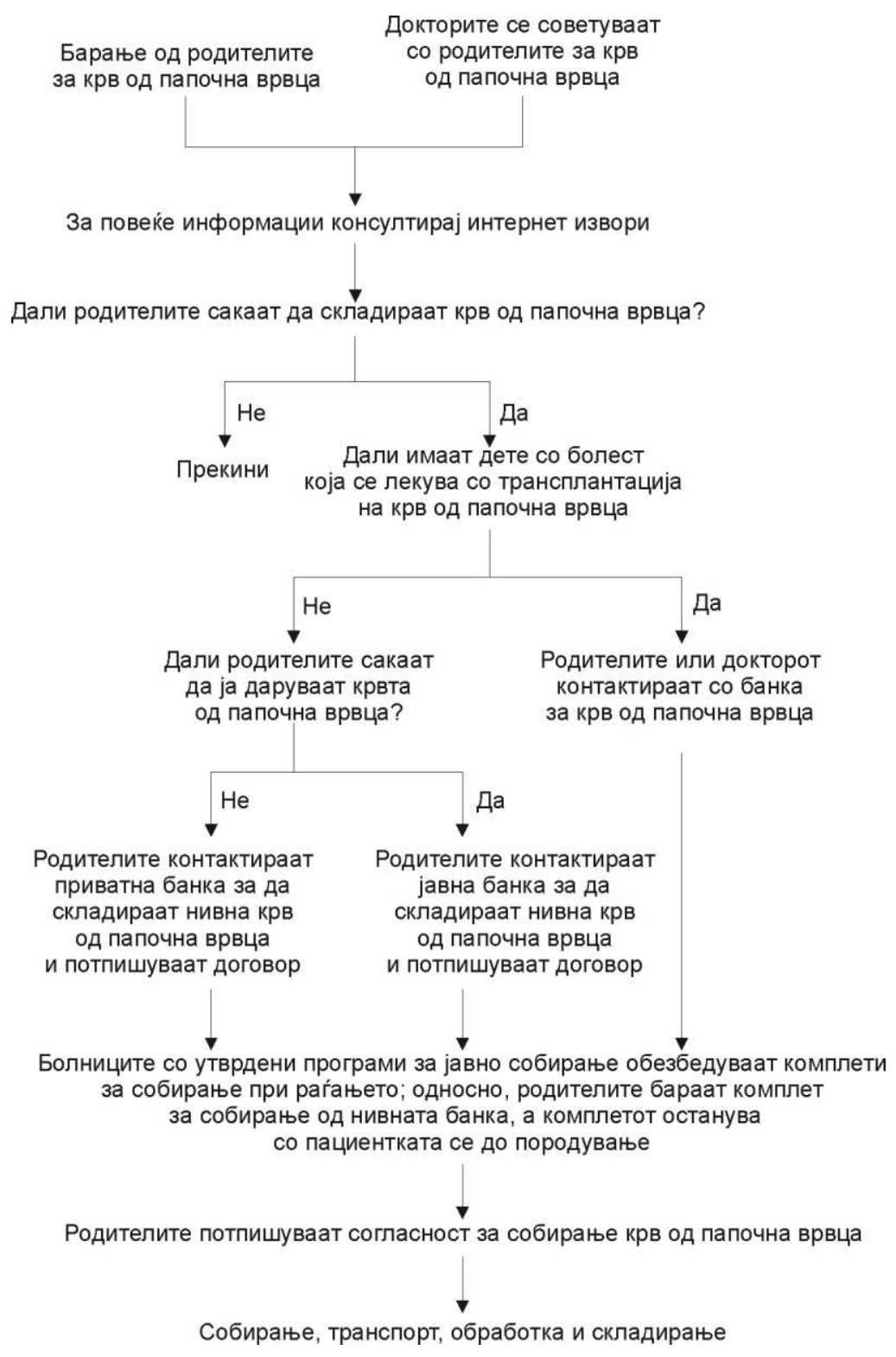

Графикон 2: Редослед на постапки за земање крв од папочна врвца

8 Comstock GW, Burke AE, Norkus EP, Gordon GB, Hoffman SC, Helzlsouer KJ. Effects of repeated freezethaw cycles on concentrations of cholesterol, micronutrients, and hormones in human plasma and serum. Clin Chem 2001;47:139-42.

$9 \quad$ Vaught JB. Blood collection, shipment, processing and storage. Cancer Epidemiol Biomarkers Prev 2006;15:1582-4. 
- складирање - за долготрајно складирање живи клетки во течен азот, пресудна е температурата. Други примероци како што е ДНК или плазма, во најголем случај се стабилни ако се чуваат на $-80^{\circ} \mathrm{C}$ во замрзнувачи или на повисоки температури ${ }^{10}$;

- процесирање - должината на фиксирање со формалин може да влијае врз подоцнежните анализи ${ }^{11}$.

Овие и други значајни препораки се вклучени во сите документи за најдобра практика на биолошки примероци. Најопширни препораки се дадени во документите од International Society for Biological and Environmental Repositories (ISBER) ${ }^{12}$ и од практиките на Nacional Cancer Institute (NCI)13. Дополнително најдобрите практики би требало да се консултираат од биобанките лоцирани на различни места во светот од каде што може да се прилагодат препораките за локална потреба и користење ${ }^{14}$.

\section{3. Општествено - економски стандарди за менаџирање со биобанки}

Помалите биобанки кои се делови од големи програми или институции, не би требале да имаат раководна структура, освен ако постојат како поголеми организации. Меѓутоа, раководењето и оперативните структури се важни за големи академски, владини и комерцијални биобанки. Овие практики обично вклучуваат раководење и план за вработените, улоги и одговорности на сите вработени, надворешни комитети кои даваат совет за научните иницијативи и ја применуваат политиката на биолошките примероци, планирање на бизнисот и враќање на трошоците, планирање и користење, како и опрема и материјали неопходни за работа ${ }^{15}$.

\section{4. Информатички практики за биобанки}

Информатиката во биобанките покрива неколку критични подрачја: следење на биолошките примероци, собирање примероци (клинички, квалитет на примероците,

$10 \quad$ NCI Best Practices for biospecimen resources. Table of contents. http://biospecimens. cancer.gov/bestpractices/toc/2011 Accessed March 6, 2012.

$11 \quad$ Khoury T, Sai S, Hwang J, et al. Delay to formalin fixation effect on breast biomarkers. Mod Pathol 2009;22:1457-67.

$12 \quad$ ISBER best practices for repositories. Cell Preserv Technol 2008;6:1-58.

13 NCI Best Practices for biospecimen resources. Table of contents. http://biospecimens. cancer.gov/bestpractices/toc/2011 Accessed March 6, 2012.

14 Vaught J, Caboux E, Hainaut P. International efforts to develop biospecimen best practices. Cancer Epidemiol Biomarkers Prev 2010;19:912-5.

$15 \quad$ NCI Best Practices for biospecimen resources. Table of contents. http://biospecimens. cancer.gov/bestpractices/toc/2011 Accessed March 6, 2012. 
демографија) и идентификација на елементите неопходни за секое испитување, сигурност на податоци и заштита на приватноста, како и интероперабилност на системите ${ }^{16}$. Интероперабилноста на информатиката на биобанките овозможува размена на податоци во рамките на биобанките кои функционираат во една мрежа. Некои други информатички проблеми за биобанките се:

- $\quad$ кој тип на пронаогање, следење, собирање на податоците и анализа на податоците ќе биде неопходен?

- дали овие потреби ги исполнуваат постоечките институционални системи или ќе биде потребно да се воведат нови комерцијални системи?

- дали ќе биде компатибилно собирањето и размената на системите во биобанката?

- дали ќе биде потребно да се создаде нов веб интерфејс за собирање на податоците?

Најдобрите практики за информатика во биобанките вклучуваат препораки за разрешување на овие прашања кога се планира нова биобанка или развој на мрежа од биобанки.

\section{5. Економски препораки за биобанки}

Многу биобанки се развиени со малку познавање за добрите бизнис практики или преку покривање на трошоците од институциите и научниците кој ги користат биолошките примероци. Меѓутоа економските препораки почнаа да се вклучуваат во најдобрите практики, вклучувајќи ги и тие од $\mathrm{NCI}^{17}$, затоа што е неопходно големи средства за собирање, процесирање и складирање на големи колекции. Овие препораки вклучуваат прилагодување на стандардните бизнис практики за да се разберат сите трошоци поврзани со започнување и одржување на биобанките. Овие трошоци вклучуваат вработени, опрема и нејзино одржување, одржување квалитет и информатика за собирањето податоци. Кога ќе се разберат добро сите овие трошоци, целосното или делумното покривање на трошоците може да обезбеди долготрајна одржливост на биобанките и да ги обесхрабри барањата за огромен број примерооци ${ }^{18}$. За многу испитувања повратокот на пари не е соодветен, бидејќ цената за собирање биолошки примероци е вклучена во проектите или договорите за подршка на истражувањето.

\footnotetext{
16 NCI Best Practices for biospecimen resources. Table of contents. http://biospecimens. cancer.gov/bestpractices/toc/2011 Accessed March 6, 2012.

$17 \quad$ Vaught J, Rogers J, Carolin T, Compton C. Biobankonomics: developing a sustainable business model approach for the formation of a national cancer human biobank by the National Cancer Institute. JNCI Monogr 2011;42:24-31.

18 Vaught J, Rogers J, Carolin T, Compton C. Biobankonomics: developing a sustainable business model approach for the formation of a national cancer human biobank by the National Cancer Institute. JNCI Monogr 2011;42:24-31.
} 


\section{6. Обезбедување квалитет на биобанки}

Едно од главните прашања поврзано со најдобрата практика на биобанките е планот за менаџирање на квалитет кој се состои од обезбедувањето квалитет и контрола на квалитетот. Дефинициите за обезбедувањето квалитет и контрола на квалитетот на биобанките е сличен на лабораториите и другите организации кои имаат такви планови за следење на активностите ${ }^{19}$. Како што е прикажано во најдобрата практика од NCI, ефективен систем за менаџирање на квалитетот бара:

- одржување на опремата и протоколи за поправка и следење;

- обучување и придржување на вработените кон препораките за работа;

- план за менаџирање на податоци;

- процедури за формално следење;

- развој и придржување кон стандардните оперативни процедури (СОП);

Специјалната природа на биобанките има потреба од упатства за стандардни оперативни процедури кои ги опишуваат следните политики и процедури:

- ракување на биолошките примероци;

- лабараториски процедури;

- протоколи за испраќање и примање на материјали;

- договори за пренос;

- систем за менаџирање на записи;

- сигурност на зградата, персоналот и биолошките примероци;

- сигурност и исфрлање на отпадот;

- процедури за испитување документи и извештаи за повреди на вработените и изложување кон опасности;

- одржување на опремата, поправка и бележење на калибрациите.

19 Centers for Disease Control and Prevention laboratory quality assurance and standardization program. http://www.cdc.gov/labstandards/ Accessed March 9, 2012. 
Овие политики и процедури треба да се користат за да се напише план за контрола на квалитетот кој ќе им помогне на надворешните контролори на биобанки и нивните менаџерски структури да го испитаат придржувањето кон СОП²0.

\section{7. Специфики при проектирање на просторот за биобанки}

\subsection{1 Примена на чиста соба ${ }^{21}$}

Постојат повеќе стандарди за примена на чиста соба зависно од тоа за што се користи. Најчесто чистите соби се конструираат за производство на процесори во информатичката индустрија, производство на стерилни фармацевтски препарати, за подготвување на матични клетки како и за други слични постапки. За сите видови чисти соби пропишани се стандарди за нивно конструирање, опремување и функционирање, од кои во овој случај ќе се користат европските препораки за добра производствена практика на медицински продукти за човечка и животинска употреба ${ }^{22}$.

Принцип: подготовката на стерилни продукти бара специјални услови за да се минимизира ризикот од микробиолошко загадување и определени пирогени загадувања. Најмногу зависат од искуството, обуката и однесувањето на вклучениот персонал. Осигурувањето на квалитет е особено важно и овој вид производство мора стриктно да ги следи внимателно утврдените и потврдени методи за подготовка и процедура. Крајната стерилност или другите аспекти на квалитет мора да бидат ставени на секој завршен или целосен продукт.

\section{Општи забелешки:}

1. Создавањето стерилни продукти треба да се изведува во простории со чист воздух во кои е строго контролиран воздухот од персоналот, од опремата и од материјалите. Чистите простории треба да се одржуваат со определена чистотота и да бидат снабдувани со воздух кој што минува низ филтри од соодветна ефикасност.

\footnotetext{
20 Master Control web site. http://www.mastercontrol.com/document-control-software/ Accessed March 9, 2012.

$21 \quad$ Centers for Disease Control and Prevention laboratory quality assurance and standardization program. http://www.cdc.gov/labstandards/ Accessed March 9, 2012.

22 EudraLex. The Rules Governing Medicinal Products in the European Union. Volume 4. EU Guidelines to Good Manufacturing Medicinal Products for Human and Veterinary Use. EUROPEAN COMMISSION

ENTERPRISE AND INDUSTRY DIRECTORATE-GENERAL: Brussels, 25 November 2008.
} 
2. Различните постапки за подготовка на продуктите како и полнењето треба да се изведува во посебни делови од чистото подрачје. Создавањето продукти се дели во две категории - прво таму каде што продуктот терминално се стерилизира и второ, таму каде што се спроведува асептично за некој или за сите стапки.

3. Чистите простори за производство на стерилни продукти се класифицираат според потребните карактеристики на околината. Секоја производствена операција бара соодветно ниво на чистота на околината во оперативна состојба, за да се минимизира ризикот од честици или микробна контаминација на продуктот или материјалите кои се создаваат.

За да се постигнат „оперативни“ услови, овие подрачја треба да се дизајнираат да постигнат определено ниво на чистота на воздухот „во мирување“. „Мирување“ е состојба кога инсталациите се инсталирани и функционираат комплетно со опремата, но не е присутен персоналот. Состојба на „оперативно“ е состојба каде што инсталациите функционираат во дефинираниот оперативен начин со определениот број на работен персонал.

Состојбите „во мирување“ и „оперативност“ треба да се дефинираат за секоја чиста соба и да одговараат на условите за чиста соба 23 :

а) „во мирување“ или „неактивност“: кога објектите и системите се целосно инсталирани и работат, но во отсуство на оператори;

б) „оперативно“ или „активност“: кога објектите и системите се во режим на работа, во присуство на на оператори.

За производство на стерилни медицински продукти се разликуваат 4 степени (Табела 1).

Степен A: локална зона со постапки од висок ризик, на пример зони на полнење, затворање шишиња, отворање ампули и шишиња, правење асептични врски. Ваквите состојки се обезбедуваат со опрема со ламинарен воздушен проток. Системите за ламинарен воздушен проток треба да обезбедат хомогена брзина на воздухот во граници од о,36 до 0,54 $\mathrm{m} / \mathrm{s}$ (препорачани вредности) во работната површина од собите со отворена работна површина. Одржувањето на ламинарноста треба да биде прикажано и валидирано. Еднонасочен воздушен проток и помали брзини може да се употребат во затворени изолатори и кутии со ракавици.

23 EudraLex. The Rules Governing Medicinal Products in the European Union. Volume 4. EU Guidelines to Good Manufacturing Medicinal Products for Human and Veterinary Use. EUROPEAN COMMISSION ENTERPRISE AND INDUSTRY DIRECTORATE-GENERAL: Brussels, 25 November 2008. 
Степен Б: за асептично подготвување и полнење, неопходно е да има околина со степен А.

Степен Ц и Д: чисти простори за изведување помалку критични постапки во подготвувањето стерилни продукти.

Чистите соби и опремата за чист воздух може да се класифицира според EN ISO 14644-1 стандардот. Максимално дозволениот број честици во воздухот е даден на Табела 1.

\section{8. Класификација на чисти соби и опрема за чист воздух}

Чистите соби и опремата за чист воздух треба да се класифицираат согласно со ЕН ИСО 14644-124. Класификацијата треба јасно да биде разликувана од условите за следење на опретивниот процес. Дозволената максимална концетрација на воздушни честици за секој степен е дадена во Табелата 1.

\begin{tabular}{|c|c|c|c|c|}
\hline \multirow[b]{3}{*}{ Степен } & \multicolumn{4}{|c|}{$\begin{array}{c}\text { Максимално дозволен број честици во т }{ }^{3} \text { еднакво на-или } \\
\text { повеќе од табеларниот број }\end{array}$} \\
\hline & \multicolumn{2}{|c|}{ Во мирување } & \multicolumn{2}{|c|}{ Во работа } \\
\hline & $0,5 \mu \mathrm{m}$ & $5,0 \mu \mathrm{m}$ & $\mathrm{o,5} \mu \mathrm{m}$ & $5,0 \mu \mathrm{m}$ \\
\hline $\mathrm{A}$ & 3520 & 20 & 3520 & 20 \\
\hline 5 & 3520 & 29 & 352000 & 2900 \\
\hline Ц & 352000 & 2900 & 3520000 & 29000 \\
\hline Д & 3520000 & 29000 & Не дефиниран & Не дефиниран \\
\hline
\end{tabular}

Табела 1: Максимално дозволен број честици во $\mathrm{m}^{3}$ во просториите во мирување и во работа за подготовка на стерилни раствори

За класификација на зоните од степен А, треба да се земе најмалку еден $\mathrm{m}^{3}$ воздух за секоја локација. За степен А класификацијата на воздушни честици стандардот ИСО 4.8 определува лимит на честиците од еднакво, или поголемо од 5,0 $\mu \mathrm{m}$. За степен Б „во мирување“ класификацијата на воздушните честици е ИСО 5 за двете предвидени големини на честиците. За степен Ц „во мирување и во операција“ класификацијата на честици во воздухот е ИСО 7 и ИСО 8. За степенот Д „во мирување“ класификацијата на воздушните честици е ИСО 8. За класификација според ЕН ИСО 14644-1, методологијата дефинира и минималниот број за секоја локација и големината врз основа на лимитот на класата на најголемите честици и методот за утврдување на собирањето податоци. Треба да се употребат преносни бројачи на честици со кратки епрувети за собирање, затоа што релативно високиот степен на преципитација „таложење“ на партиклите еднакво, или 
поголеми од 5,о $\mu \mathrm{m}$ кој се случува во оддалечените системи за земање примероци со голема должина на епруветата. Треба да се користат изокинетски глави за собирање кои користат систем на еднонасочен проточен воздух. Класификацијата „во операција“ може да се прикаже за време на нормално функционирање, симулирано функкционирање или за време на полнењето медиум како најлоша симулација неопходна за овој стандард. ЕН/ИСО 146442 дава информации за тестирањето и прикажува континуирана усогласеност со класификацијата на чистотата.

\section{4. Стратешко планирање и намена на просторот за банка за матични клетки}

Според физибилити студијата, идејниот проект за биобанка за матични клетки треба де се лоцира во простор наменет за медицинска установа во Република Македонија (Слика 2). Просторот е составен од $105 \mathrm{~m}^{2}$ за биобанка на матични клетки, како и простор за лифт, скали и подест, санитарии машки, санитарии женски, хидростаница и ходник.

Локацијата е предвидена во кругот на Медицинскиот факултет, до Фармацевтскиот факултет, спроти Универзитетската клиника за инфективни болести и фебрилни состојби во Скопје. До објектот ќе се обезбеди пристап со асфалтиран пат од три страни. Во ниво на локацијата треба да се предвиди пристап до цистерна со $\mathrm{N}_{2}$ сместена на ниво на локацијата. Исто така ќе се обезбеди главен влез во објектот од југоисточната страна преку пешачка зона (од улицата спроти Универзитетската клиника за инфективни болести и фебрилни состојби).

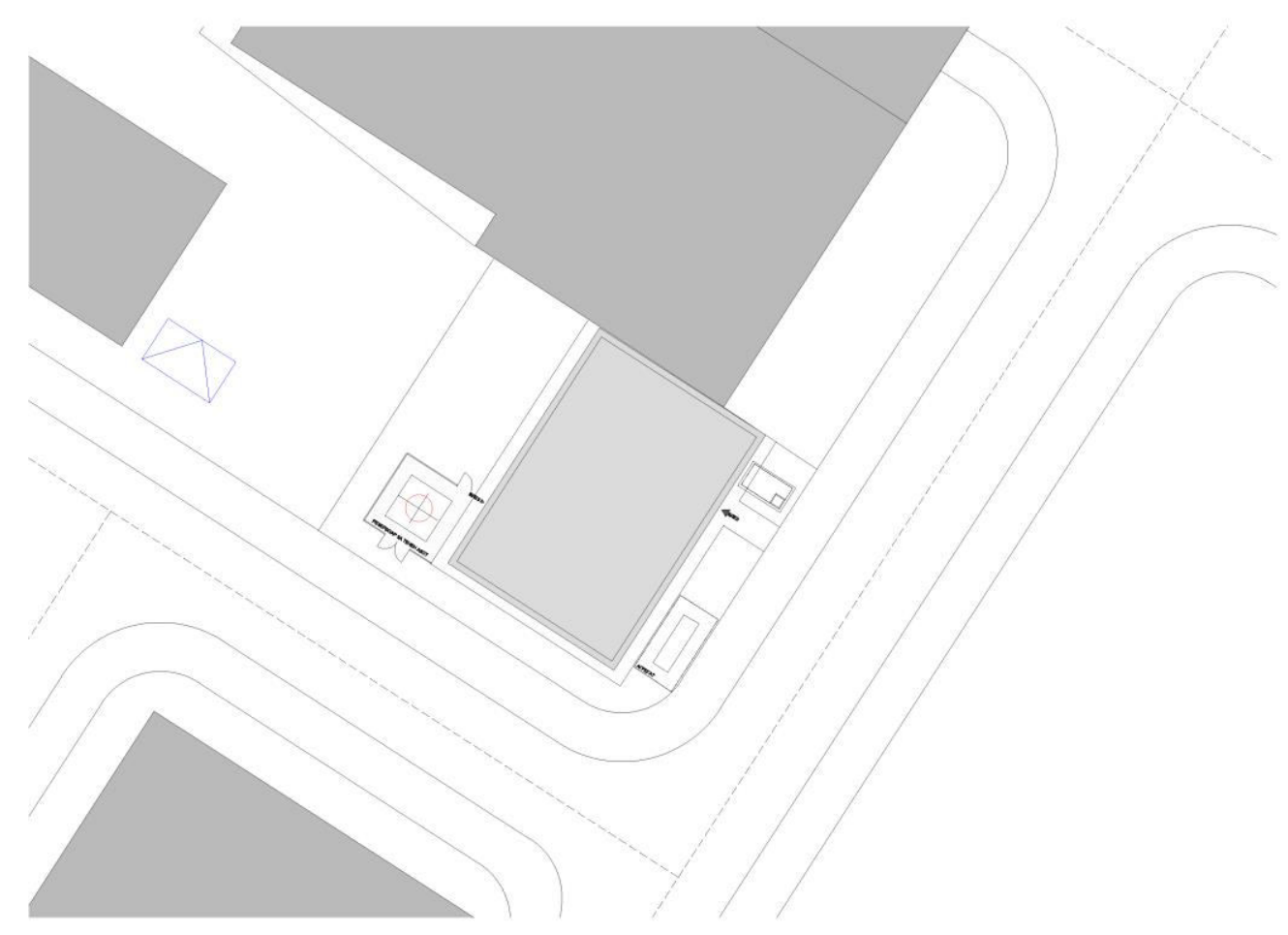

Слика 2. Локација на банката за матични клетки 
Постојните потреби на биобанката зависат од дејностите кои треба да ги обавува во своите организациони единици.

Начинот на паркирање и местоположбата на паркинзите зависи од поставеноста на предметниот објект во однос на постоечката сообраќајна инфраструктура. Обезбедувањето на пристап за паркинг место е овозможено според правилникот за стандарди и нормативи за урбанистичко планирање.

\section{1. Функционален аспект на проектната анализа}

На дадениот локалитет, предвиден е објект за образование и наука, кој согласно програмските барања и условите за градба е проектиран како објект со катност од П+1, односно со висина на венец $6,5 \mathrm{~m}$.

Во првото ниво - подрум е обезбеден простор за банка за матични клетки, простор за лифт (машинска станица) и простор за хидростаница (со топлотна единица).

На ниво на приземје се предвидени влезен дел со простор за прием на пациенти, кабинети и соба за едукација.

На катот се сместени лабораториите и раководителот на установата.

\section{ЛАБОРАТОРИИ}

\section{подрум}

\section{БИОБАНКА}

Дијаграм 1: Функционална поделба на објектот по катови 


\section{2. Техничко - конструктивен аспект на проектната анализа}

Главна носива конструкција на објектот е скелетен армиранобетонски систем (Сл. 5) од армиранобетонски столбови и греди поставени во два ортогонални правци со дебелина од $\mathrm{d}=20 \mathrm{~cm}$ и $\mathrm{d}=35 \mathrm{~cm}$. Меѓукатната конструкција е од армиранобетонски монолитно изведени плочи со дебелина од $15 \mathrm{~cm}$ на катовите и со дебелина $18 \mathrm{~cm}$ на скалишното јадро. Столбовите од конструкцијата се предвидени да имаат димензии кои ке зависат од нивната местоположба во основата.

Надворешните подрумски sидови се предвидени со дебелина од $\mathrm{d}=35 \mathrm{~cm}$. Темелењето е на армиранобетонска темелна плоча со дебелина $\mathrm{d}=70 \mathrm{~cm}$. Вака предвидената и проектирана конструкција во потполност би одговорила на сите постојани и корисни гравитациони оптоварувања, а и на случајните хоризонтални сеизмички оптоварувања, кои можат да ја оштетат професионалната опрема.

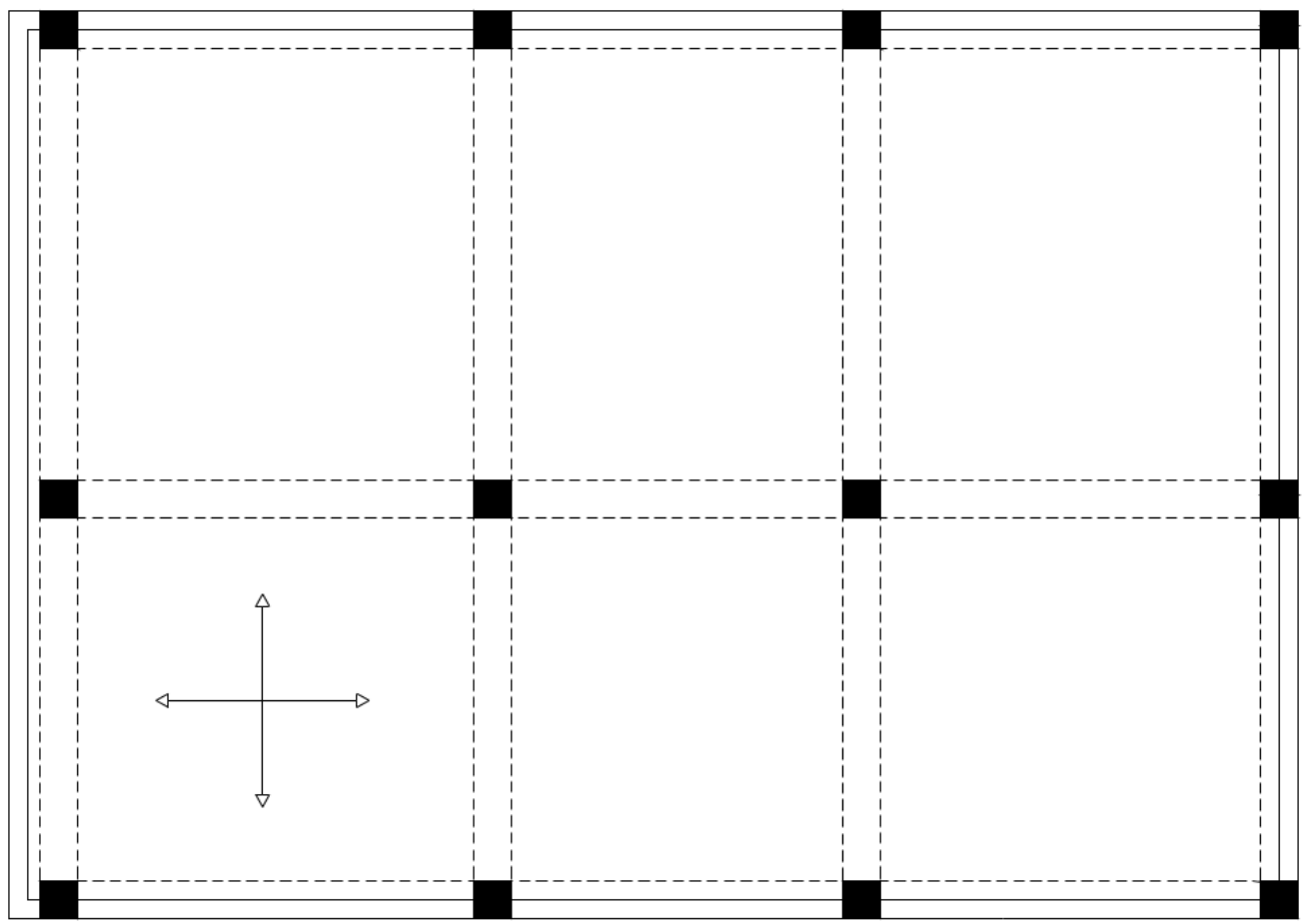

Слика 3: Склетен армиранобетонски систем 
Во рамките на скелетниот систем се развива на три нивоа, армиранобетонско скалишно и лифтовско јадро кое овозможува вертикална комуникација во објектот.

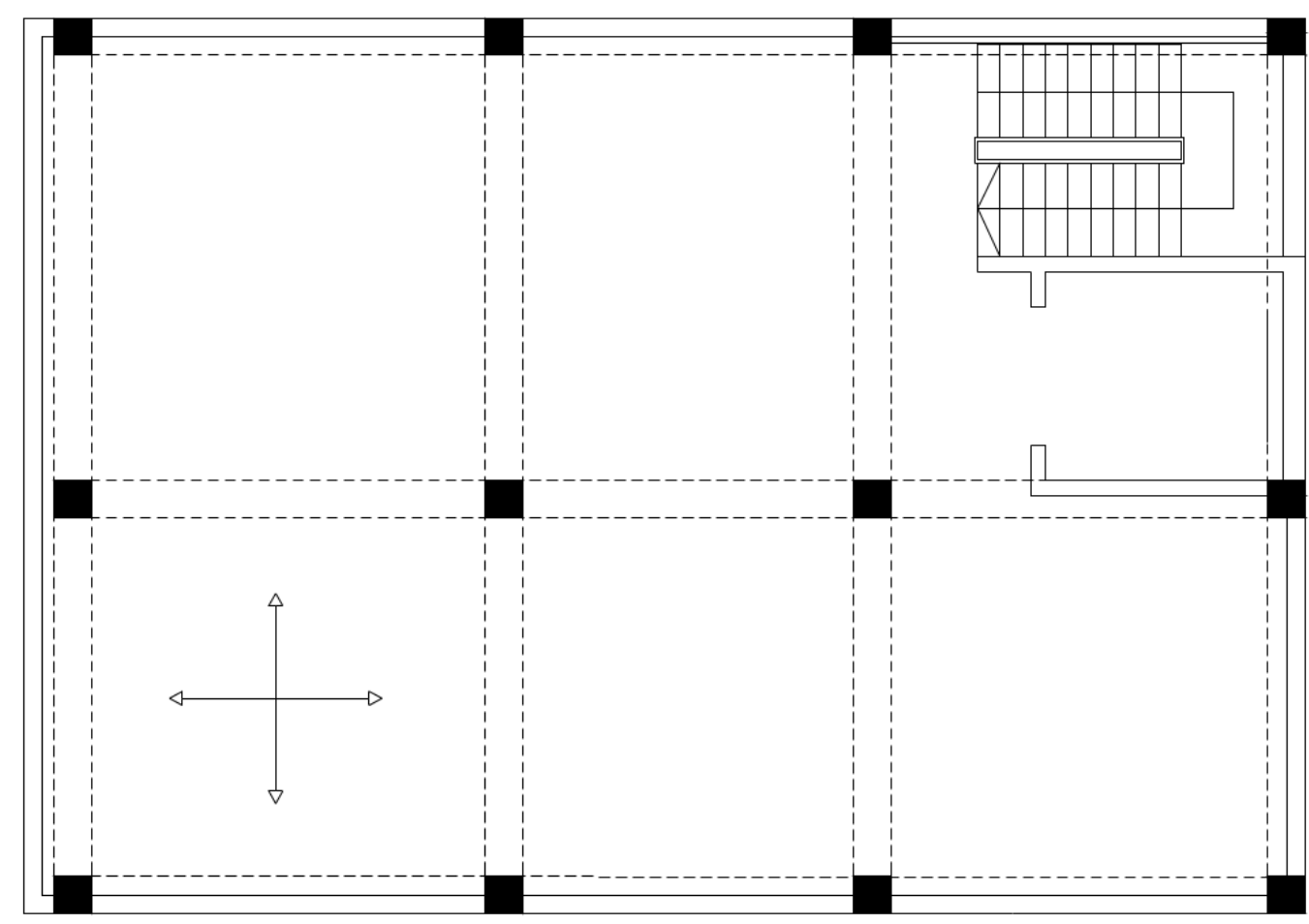

Слика 4: Склетен армирано бетонски систем со скалишно и лифтовско јадро

4.3. Физибилити студија за намената на објектот

Во Република Македонија трансплатацијата на хематопоетски стем клетки (ТХСК), започна во 2000 год. на Универзитетската клиника за хематологија при Медицинскиот факултет во Скопје. Од тогаш до 2011 год. се изведени вкупно 267 трансплантации, или во просек 20,5 трансплантации годишно. Од тие трансплантации, 194 биле направени со свои матични клетки или автологни трансплантации, а 73 биле направени од туѓ матични клетки или алогени трансплантации (Графикон 3). 


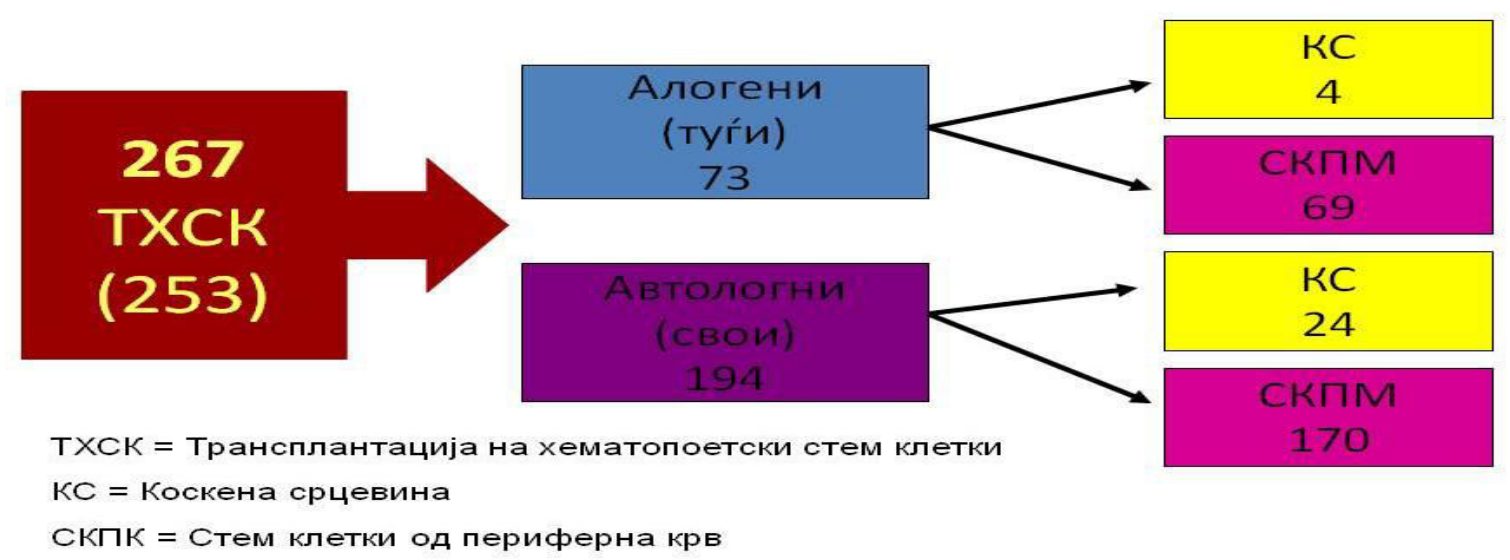

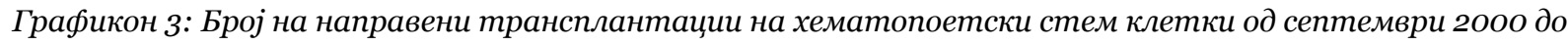
септември 2011 на Универзитетска клиника за хематологија при Медицинскиот факултет во Скопје

Од овие резултати се гледа дека најмалку 20 трансплантации на хематопоетски стем клетки се неопходни во Република Македонија. Овој број е неколкупати поголем ако се знае дека кај сите пациенти е направена трансплантација од роднини (браќа или сестри), а за останатите нема соодветен дарител.

Поради тоа во Република Македонија постојат поголем број претставништва на странски банки за матични клетки од папочна врвца кои собираат примероци и ги испраќаат во странство. Само за годините 2007, 2008 и 2009 собрани се и испратени во странство над 1000 примероци од крв од папочна врвца (Табела 2).

\begin{tabular}{|l|c|c|c|c|}
\hline $\begin{array}{l}\text { Претставник во } \\
\text { Македонија }\end{array}$ & $\mathbf{2 0 0 7}$ & $\mathbf{2 0 0 8}$ & $\mathbf{2 0 0 9}$ & Вкупно \\
\hline Cryo-Save & 42 & 268 & 261 & 571 \\
\hline Biohelenika & 10 & 40 & 30 & 80 \\
\hline Cellgenea & 50 & 150 & 100 & 300 \\
\hline CryoGenomics & 15 & 30 & 50 & 95 \\
\hline Future Health & - & - & 6 & 6 \\
\hline Вкупно & 117 & 488 & 447 & 1052 \\
\hline & & & & \\
\hline
\end{tabular}

Табела 2: Бројот на примероци крв од папочна врвца од Република Македонија земени и складирани во странски банки за матични клетки во период од 2007 до 2009 година

Иако нема податоци за бројот на земени примероци крв од папочна врвца кои се испратени во странство, се претпоставува дека овој број изнесува повеќе од 1000 примероци годишно. Ако се знае дека складирањето на еден примерок изнесува околу 1400 евра, може да се пресмета дека годишно се одлеваат над 1400 ооо евра за оваа намена. 
Од овие податоци произлегува потребата за изградба и функционирање на банка за матични клетки во Република Македонија. Проектот прикажан во овој магистерски труд за дизајнирање на банка за матични клетки во некоја приватна или здравствена установа би овозможил задоволување на потребите не само за Република Македонија туку и за Република Косово и Република Албанија.

\section{5. Организација на проектот}

5.1. Дефинирање на проектните потреби и насоки

Со оваа проектна програма се даваат насоки за изготвување на основен проект, а според усвоеното архитектонско решение од страна на инвеститорот. Проектот треба да биде изработен согласно издадениот извод од урбанистички план и важечката законска регулатива, а воедно да се надоврзе на проектната програма на инвеститорот.

Цел на оваа проектна програма е да ги дефинира барањата и потребите на инвеститорот при изработката на основниот проект за банка за матични клетки. Понуденото архитектонско - градежно решение треба да овозможи непречено одвивање на технолошките процеси посочени од инвеститорот. Решението треба да биде оптимално во однос на функција, конструкција и економичност. Основниот проект - архитектура за банка за матични клетки да се изготви со почитување на сите градежно - технички прописи и нормативи, кои се однесуваат за објекти од образование и наука за да може врз основа на истиот да се добие дозвола за градба.

Во приземјето да се проектира:

- $\quad$ влезен хол со чекална $\approx 40 \mathrm{~m}^{2}$;

- $\quad$ простор за прием на пациенти $\approx 6 \mathrm{~m}^{2}$;

- $\quad$ просторија за земање примероци $\approx 11 \mathrm{~m}^{2}$;

- санитарии за пациенти $\approx 15 \mathrm{~m}^{2}$;

- санитарија за лица со посебни потреби $\approx 5 \mathrm{~m}^{2}$;

- $\quad$ соба за едукација $\approx 45 \mathrm{~m}^{2}$;

- $\quad$ кабинет за молекулска медицина $\approx 8 \mathrm{~m}^{2}$;

- $\quad$ кабинет за хумана генетика $\approx 8 \mathrm{~m}^{2}$;

- $\quad$ кабинет за молекуларна медицина $\approx 8 \mathrm{~m}^{2}$.

Да се предвидат вертикални комуникации-скали и лифт,кои треба да се постават така да бидат видливи од влезот, и кои ќе имаат пристап до ниво $-3,84 ; \pm 0,00 ;+3,60$; а скалите ќе имаат пристап и до ниво +11,53 за излез на покривна тераса. 
На први кат да се проектираат лаборатории и кабинет за потребите на банката за матични клетки и тоа:

- $\quad$ лабораторија за проточна цитометрија $\approx 24 \mathrm{~m}^{2}$;

- лабораторија за алергологија и серолошка имуногенетика $\approx 32 \mathrm{~m}^{2}$;

- $\quad$ лабораторија за протеини и автопротивтела $\approx 28 \mathrm{~m}^{2}$;

- лабораторија за молекуларна имунологија $\approx 20 \mathrm{~m}^{2}$;

- кабинет за раководител на банката $\approx 10 \mathrm{~m}^{2}$;

- $\quad$ оставишен простор $\approx 3 \mathrm{~m}^{2}$;

- $\quad$ санитарии за вработени $\approx 8 \mathrm{~m}^{2}$.

Да се проектира и излез на скалишното јадро на покривната тераса на кота $+11,53$, заради опслужување на клима комората и килерот.

Во подрумот, на кота -3,84 да се испроектира банка за матични клетки и потребните технички простории:

- банка за матични клетки $\approx 100 \mathrm{~m}^{2}$;

- $\quad$ машинска просторија $\approx 16 \mathrm{~m}^{2}$;

- $\quad$ хидростаница $\approx 6 \mathrm{~m}^{2}$;

- санитарии за вработени $\approx 8 \mathrm{~m}^{2}$;

- $\quad$ Sидовите и плафонот на коморите да се изведат од сендвич панели: лим - полиуретан - лим за да се овозможи постигнување на потребната температура;

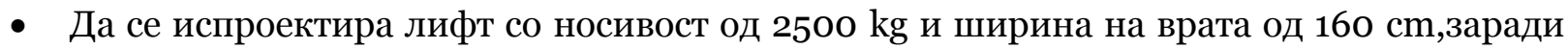
потребите на банката за матични клетки;

- Да се предвидат подови, sидови, врати, прозори соодветни за овој тип на објекти;

- Од лабораториите од први и втори кат да се предвиди засебен канал за дигестори;

- На ниво на ситуација да се предвиди простор за поставување на: цистерна за течен азот, клима комора за банката за матични клетки, противпожарен орман за чување на запаливи материи и агрегат;

- Клима комората и килерот за климатизација на објектот да се сместат на покривната тераса. 


\section{2. Развој на прелиминарниот проект}

\begin{tabular}{|c|}
\hline 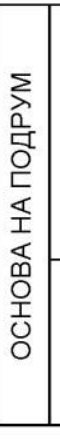 \\
\hline
\end{tabular}

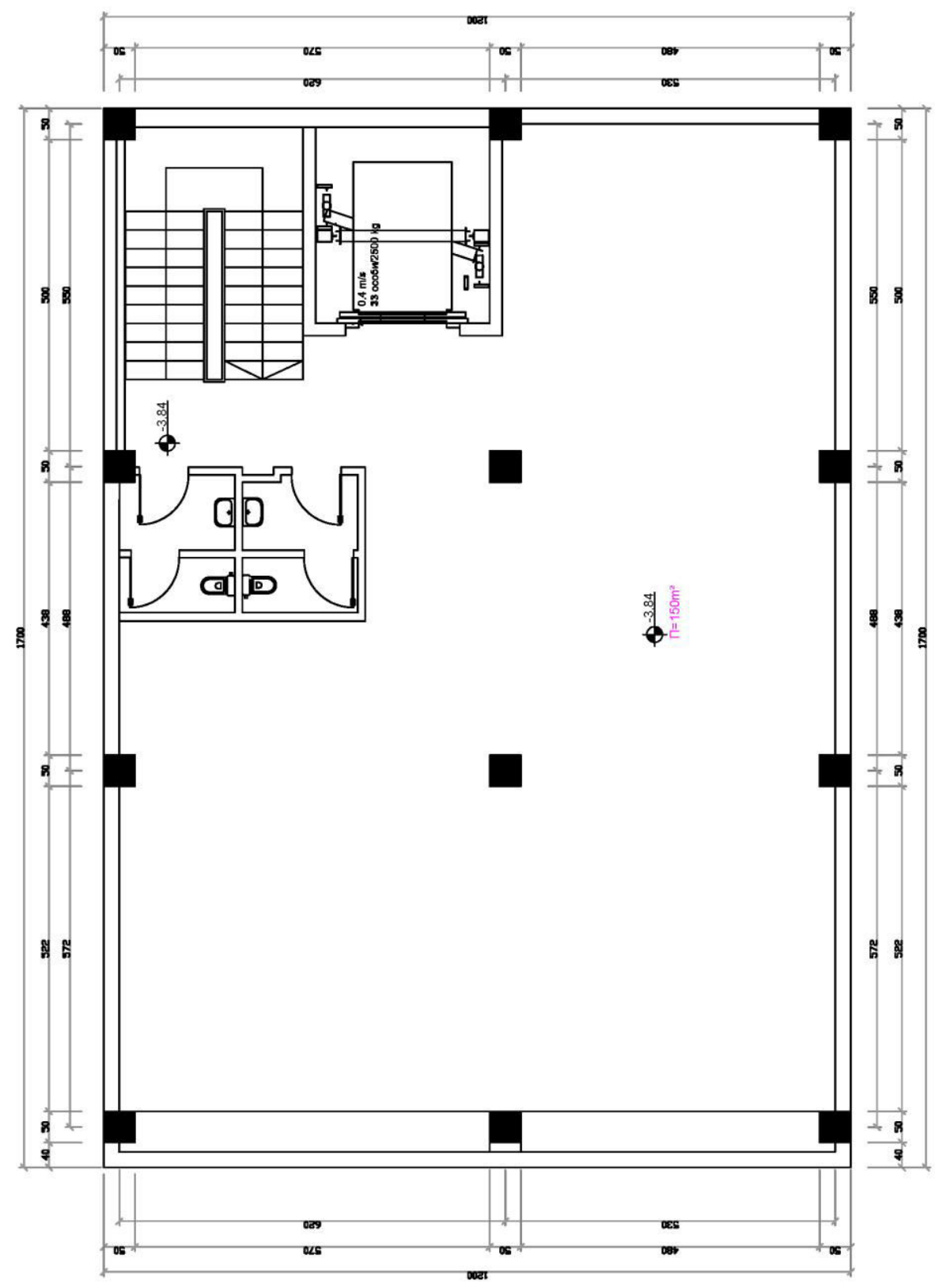




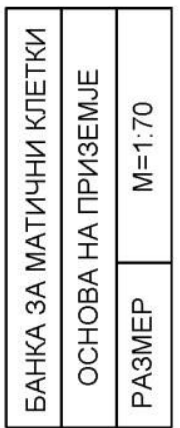

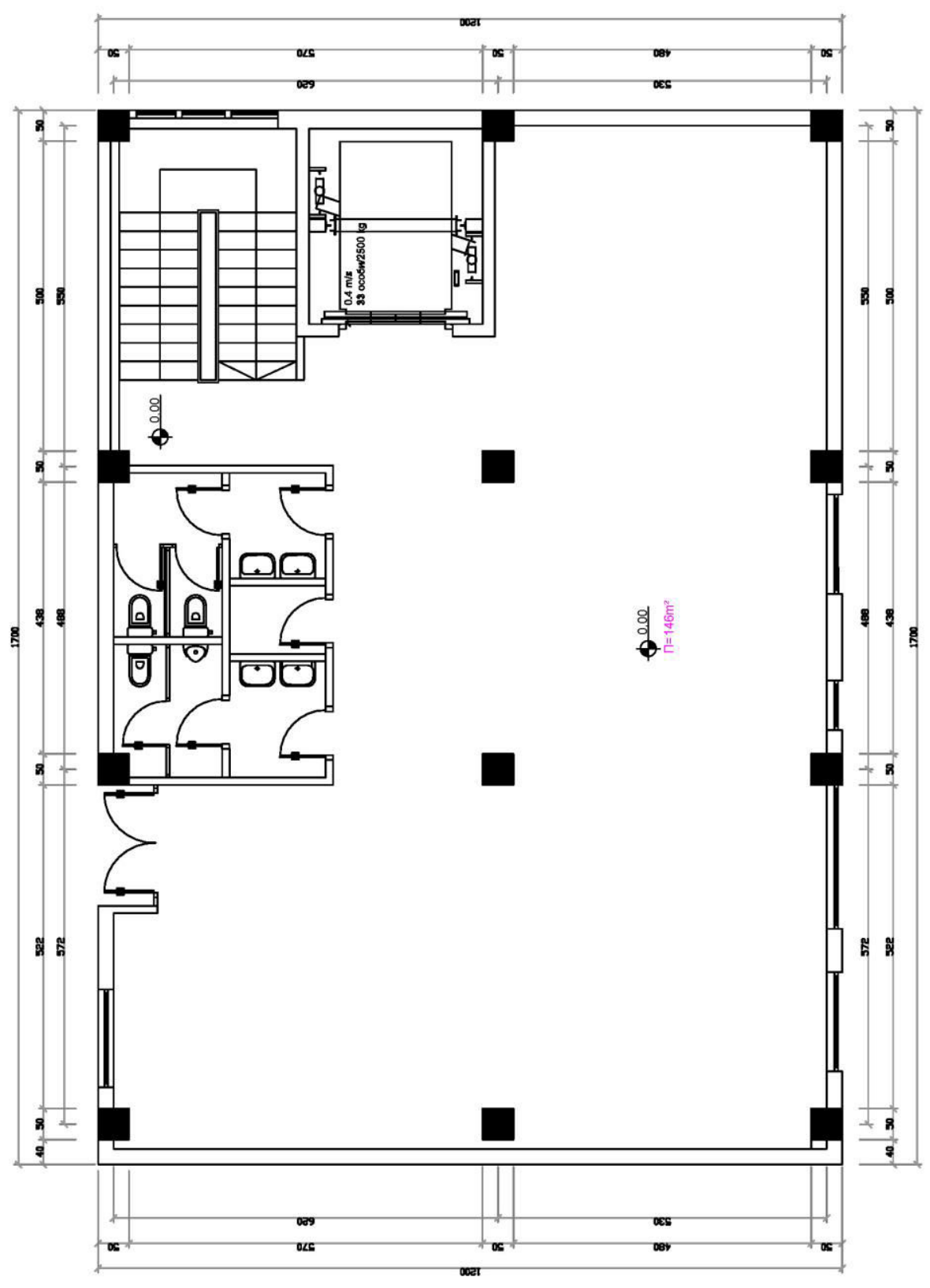

Слика 6: Основа на приземје 

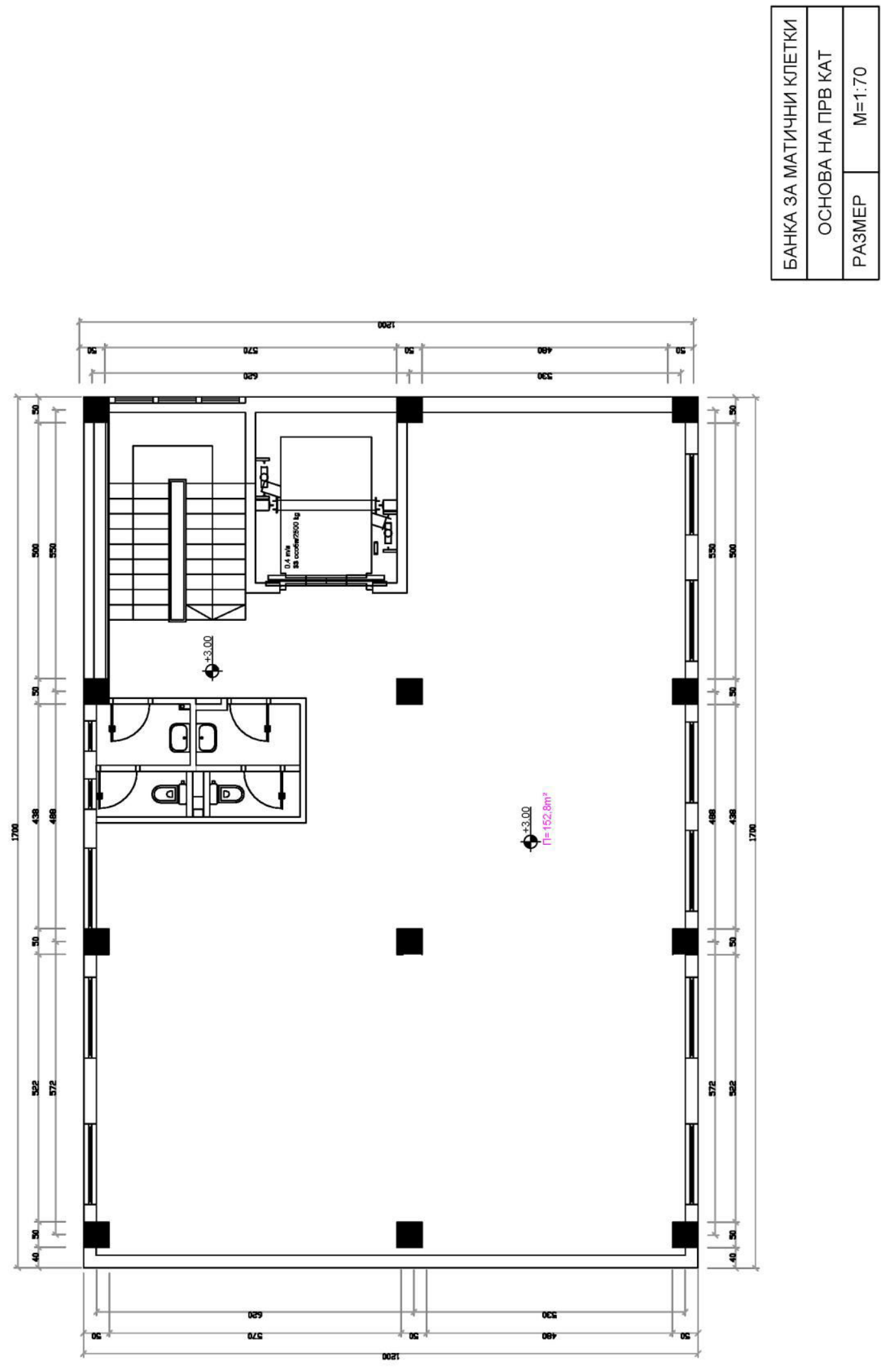

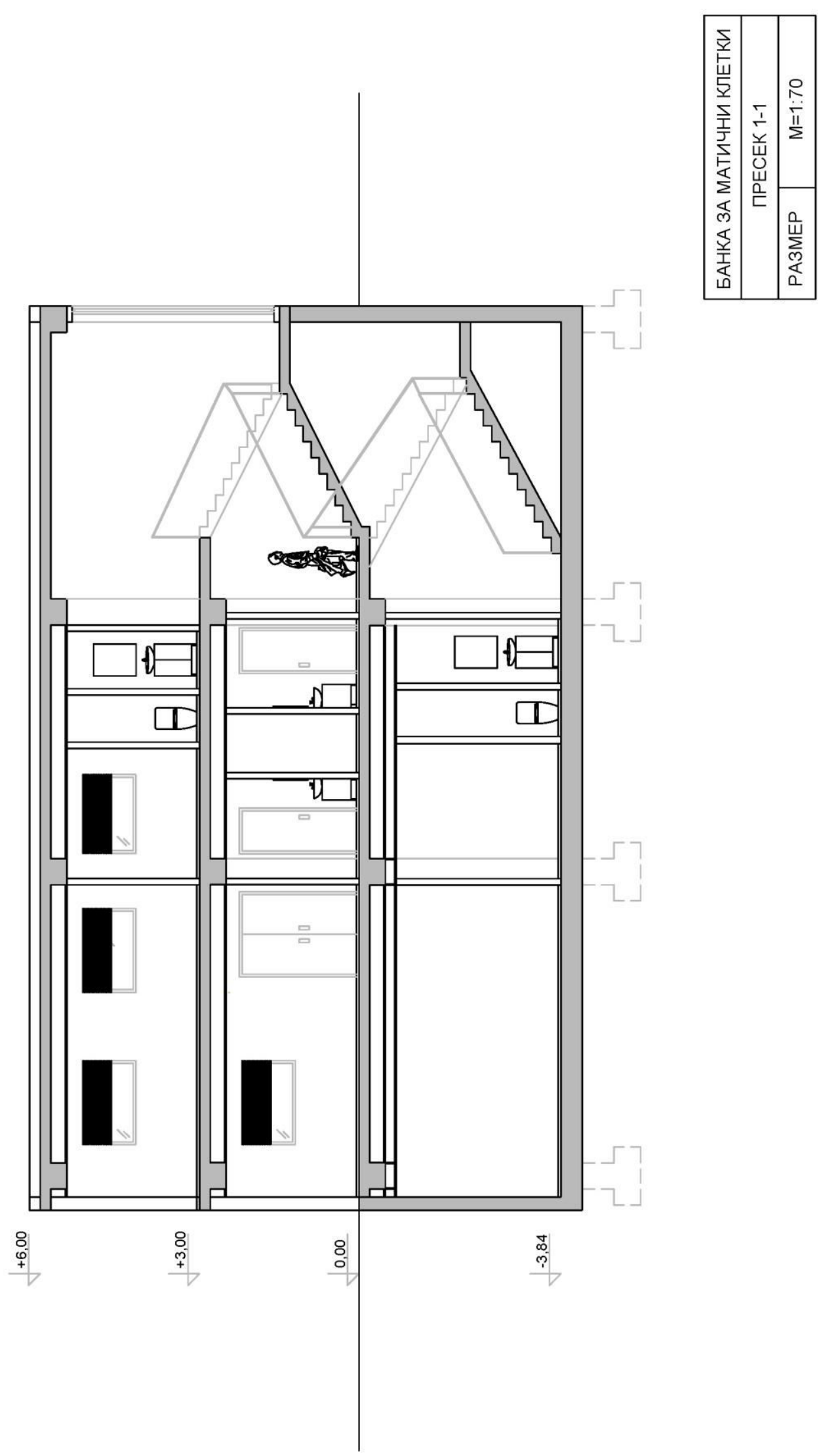

Слика 8: Пресек на основата 1-1 


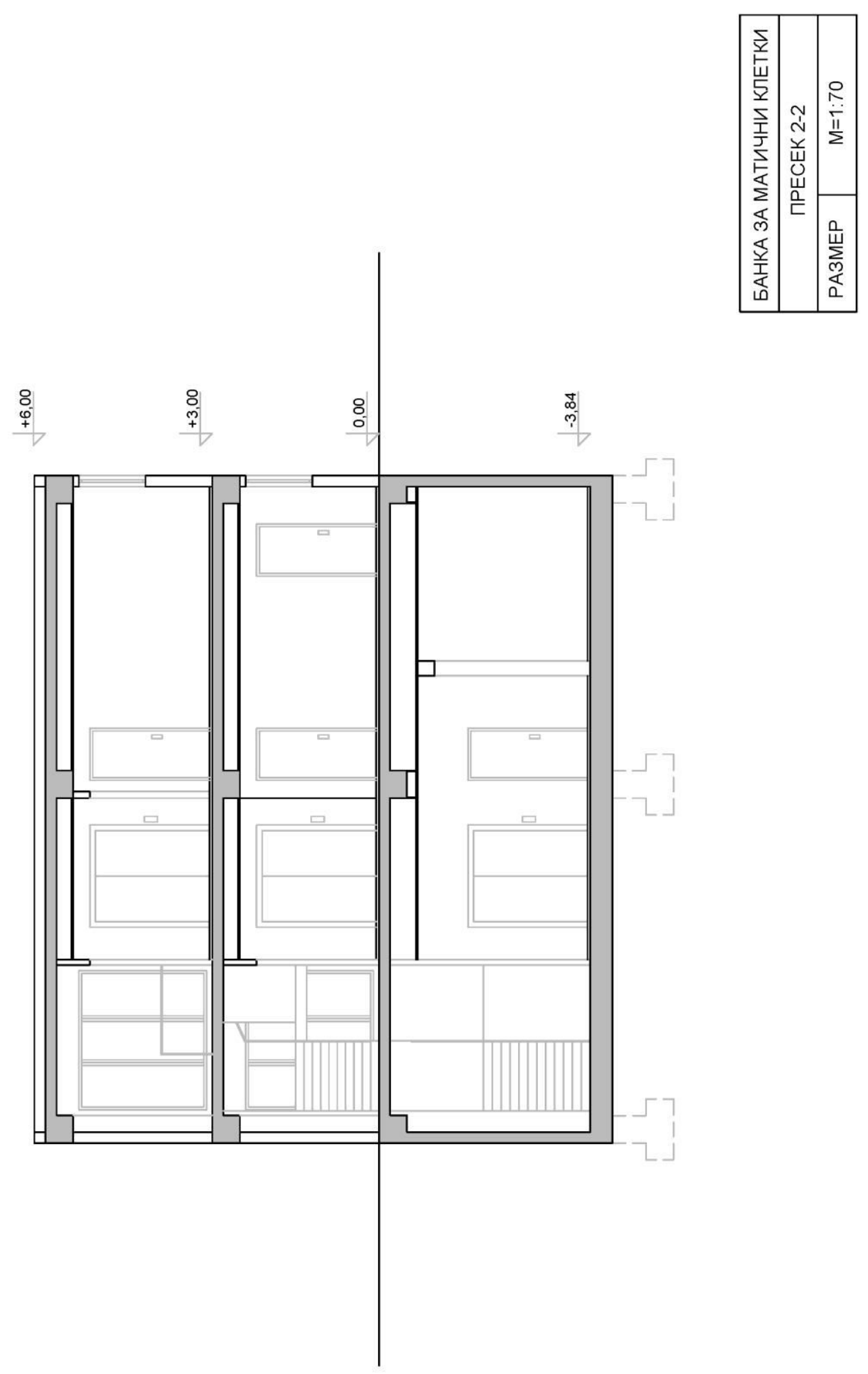




\section{3 Условености кои призлегуваат од проектот на објектот}
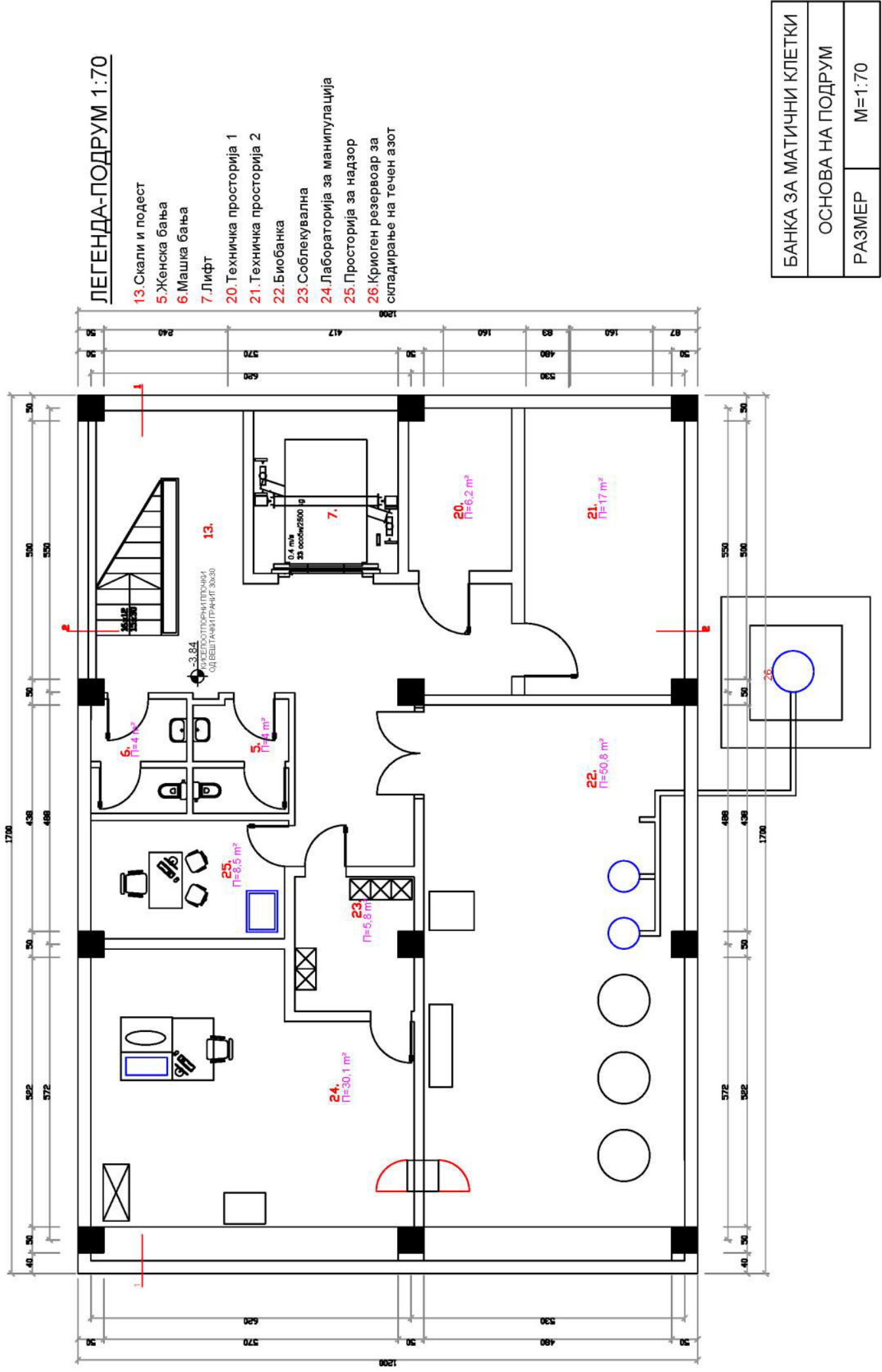

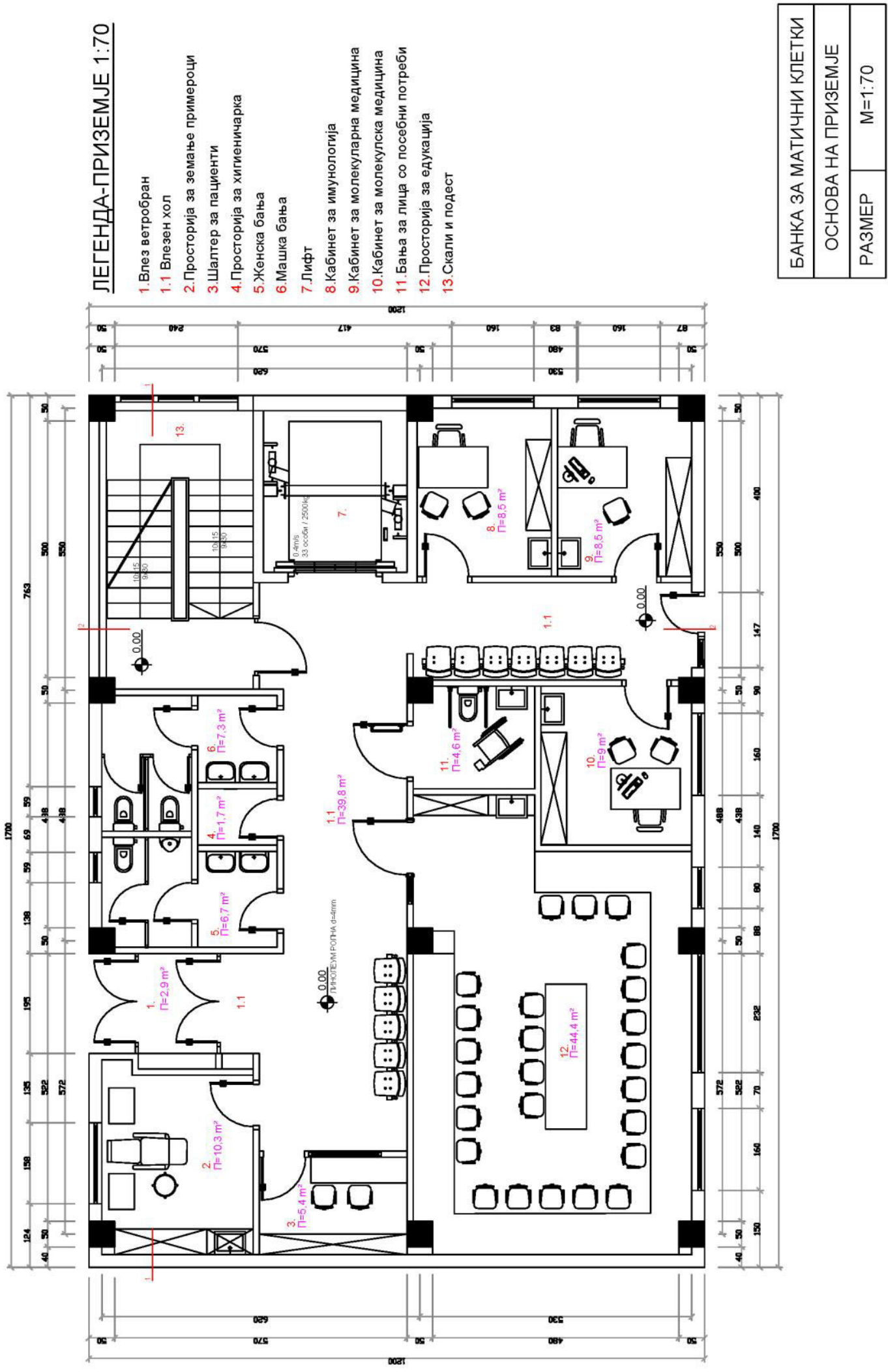

Слика 11: Основа на приземје 


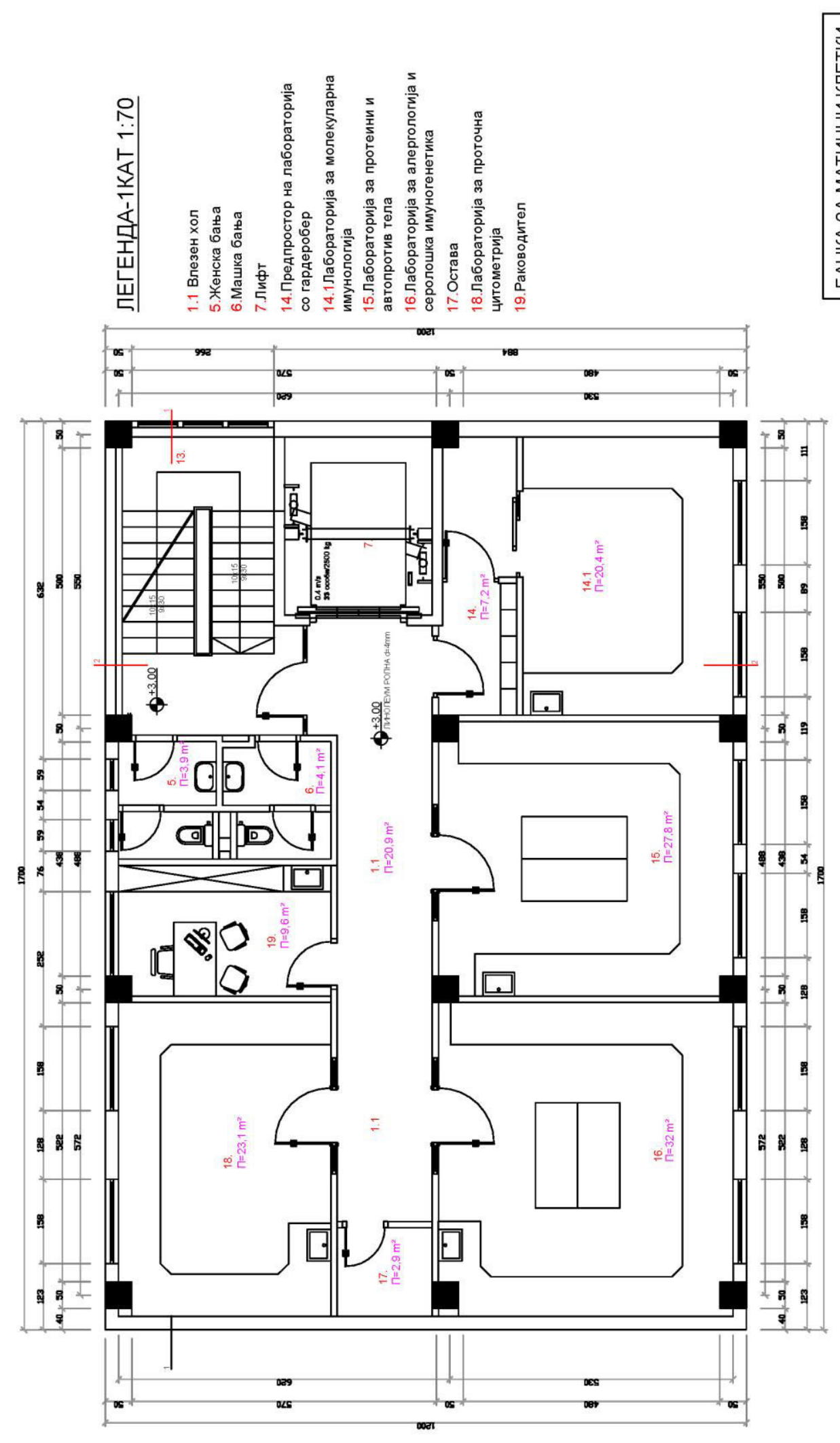

Слика 12: Основа на прв кат 

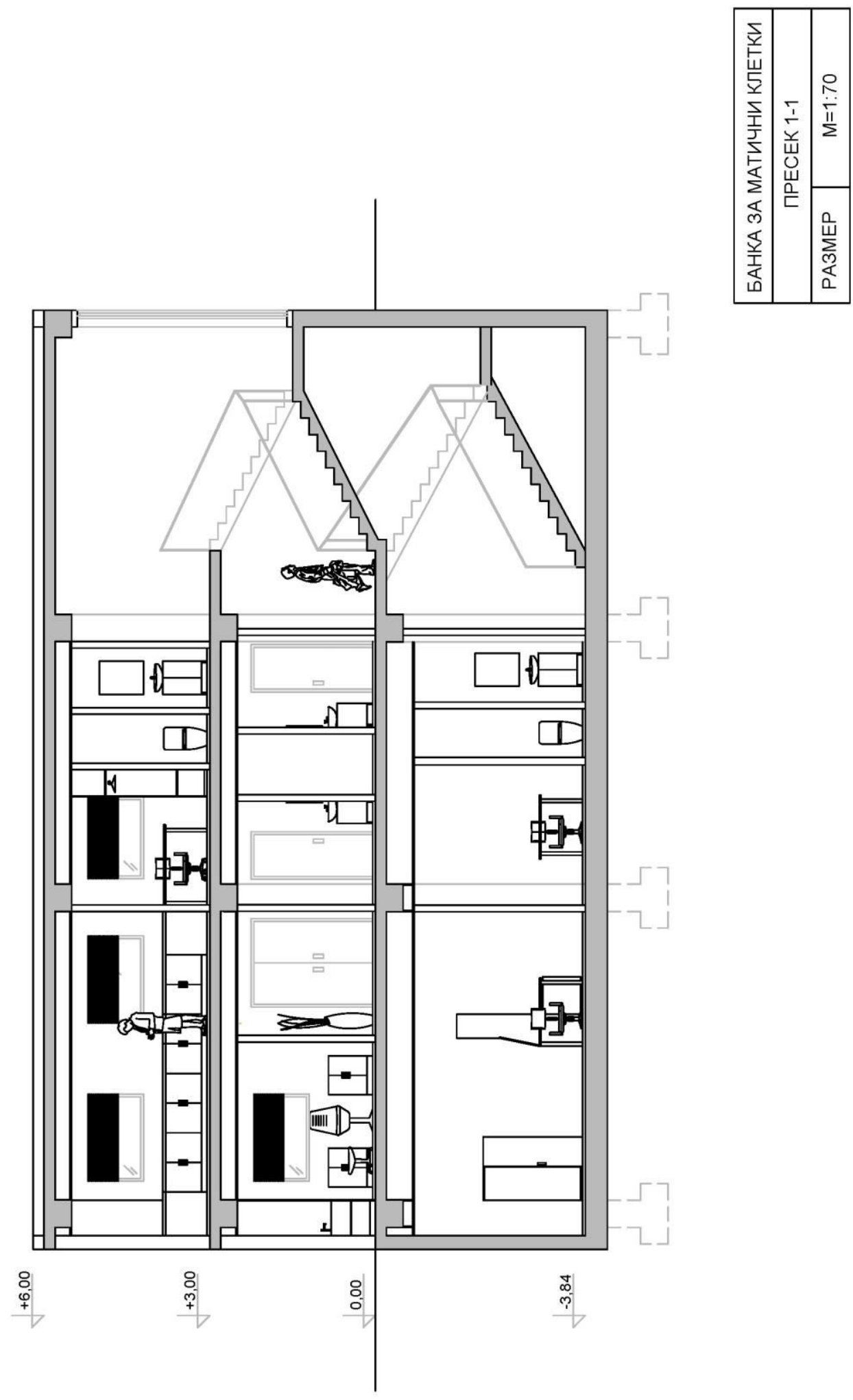


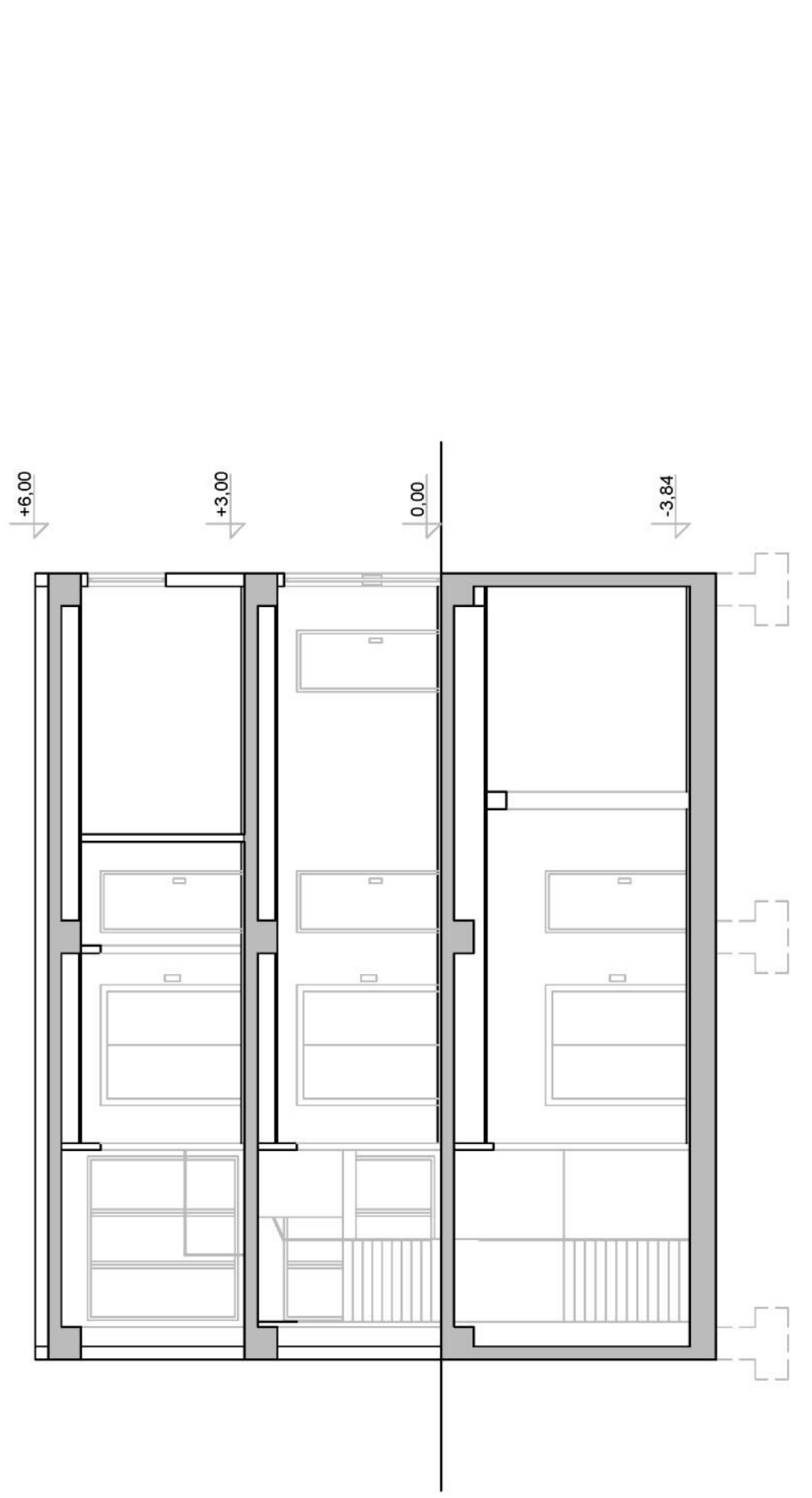




\section{6. Анализа на елементите на ентериерот}

6.1. Анализа на проектот за мебел изработен по проект за дадениот простор

6.1.1. Просторија за складирање на матични клетки

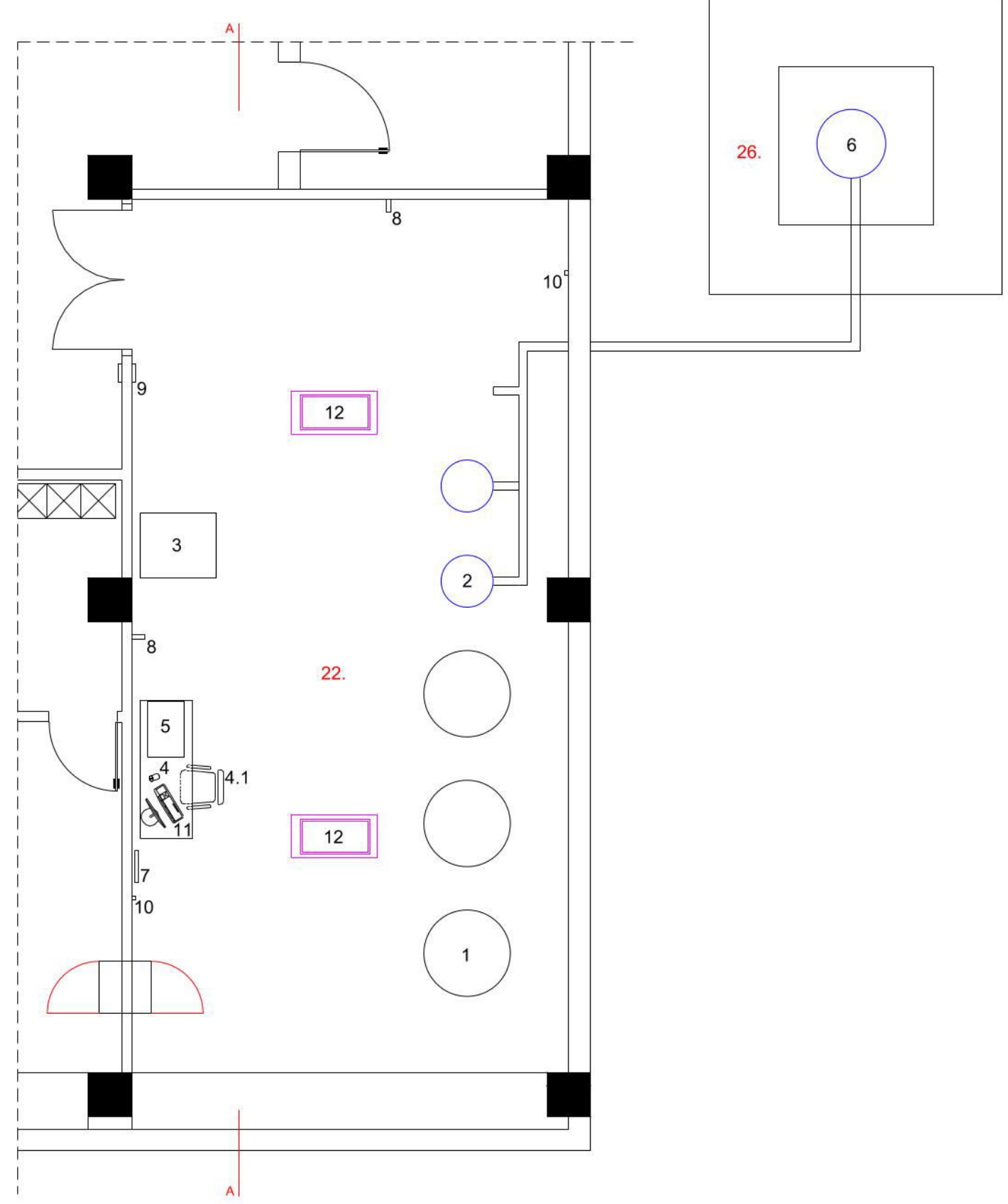

Слика 15: Основа на просторот за складирање на матични клетки

Применет мебел за опремување на просторот за складирање на матични клетки:

4. работна површина од не'рѓосувачки челик со димензии (160 х 60 x 80);

4.1 стол од не' рѓосувачки челик. 
Применета професионална опрема во просторот за складирање на матични клетки:

1. три оперативни dewar садови MVE Chart за складирање на примероци од крв од папочна врвца во гасна фаза;

2. два dewar сада (еден за карантин) за транспорт на примероци од крв од папочната врвца во азотна гасна фаза;

3. $-85^{\circ} \mathrm{C}$ замрзнувач, опремен со запишувач на податоци и поддршка од $\mathrm{CO}_{2}$ за снабдување во итни случаи;

4. еден Planer замрзнувач за примероци од крв од папочна врвца и сад под притисок за внатрешно снабдување со течен азот до Planer замрзнувач;

5. еден надворешен резервоар со течен азот со телеметриски систем за следење на работните параметри, со капацитет од 10.000 литри, за снабдување со азот до садовите под притисок преку супер-изолиран вакуумски цевковод;

6. сонда за мерење на температурата и сонда за мерење на влажноста, поврзани со централниот систем за надзор;

7. два детектори за кислород поставени на 80 cm од подот;

8. еден надворешен систем со беџови за влез + еден внатрешен систем со беџови за контрола;

9. две контролни зидни копчиња за итни случаи;

10. еден печатач + еден баркод читач за управување со следливоста и еден компјутер;

11. Систем за вентилација со постојана промена на воздухот со капацитет $10 \mathrm{vol} / \mathrm{h}$ во стандардни услови, $25 \mathrm{vol} / \mathrm{h}$ во вонредни услови;

12. систем за видео надзор, поврзан со централниот систем за надзор и рекордер. 


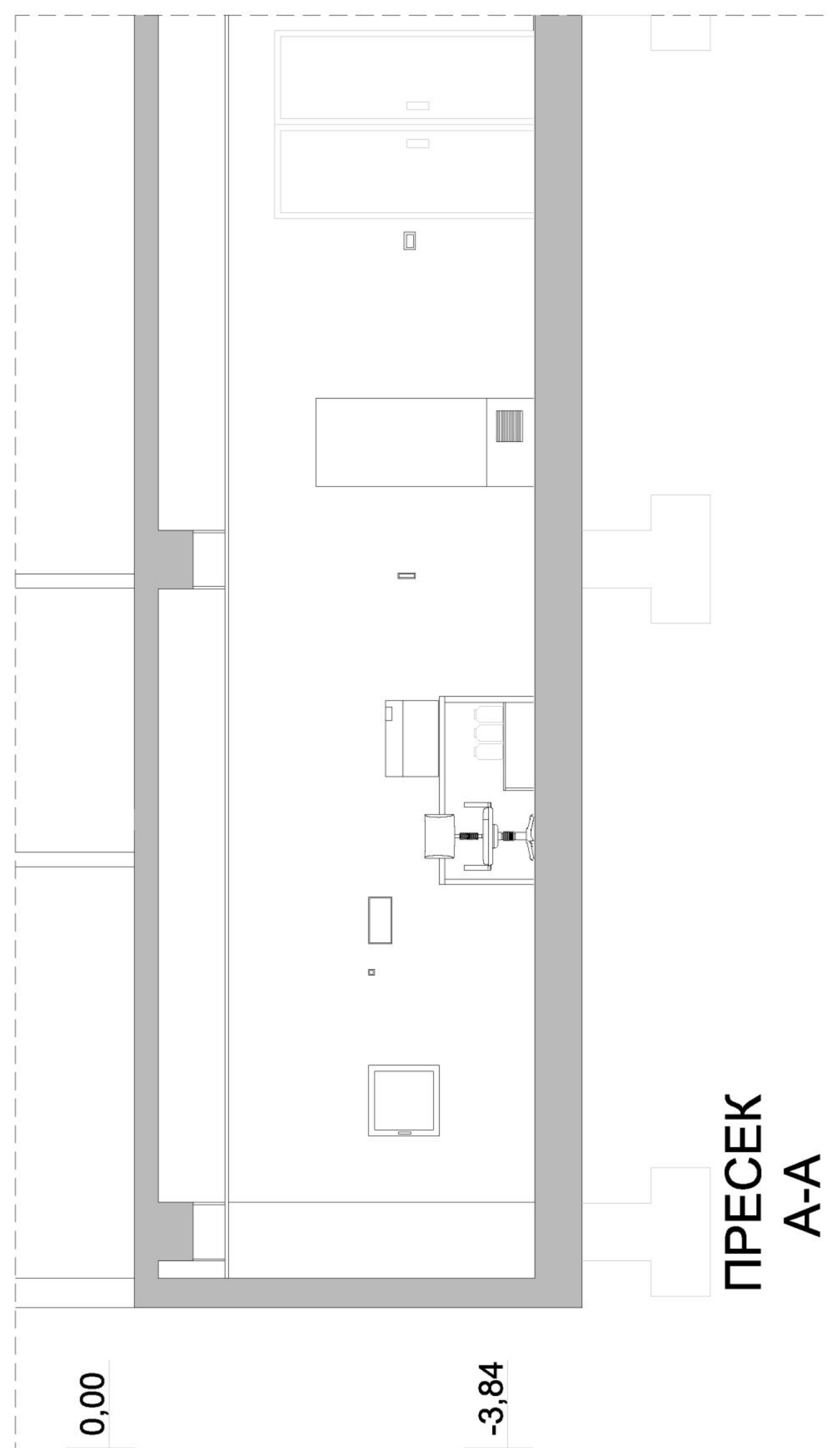

Слика 16: Изглед на просторот за складирање на матични клетки Б-Б 


\subsection{2. Просторија за изолација на матични клетки}

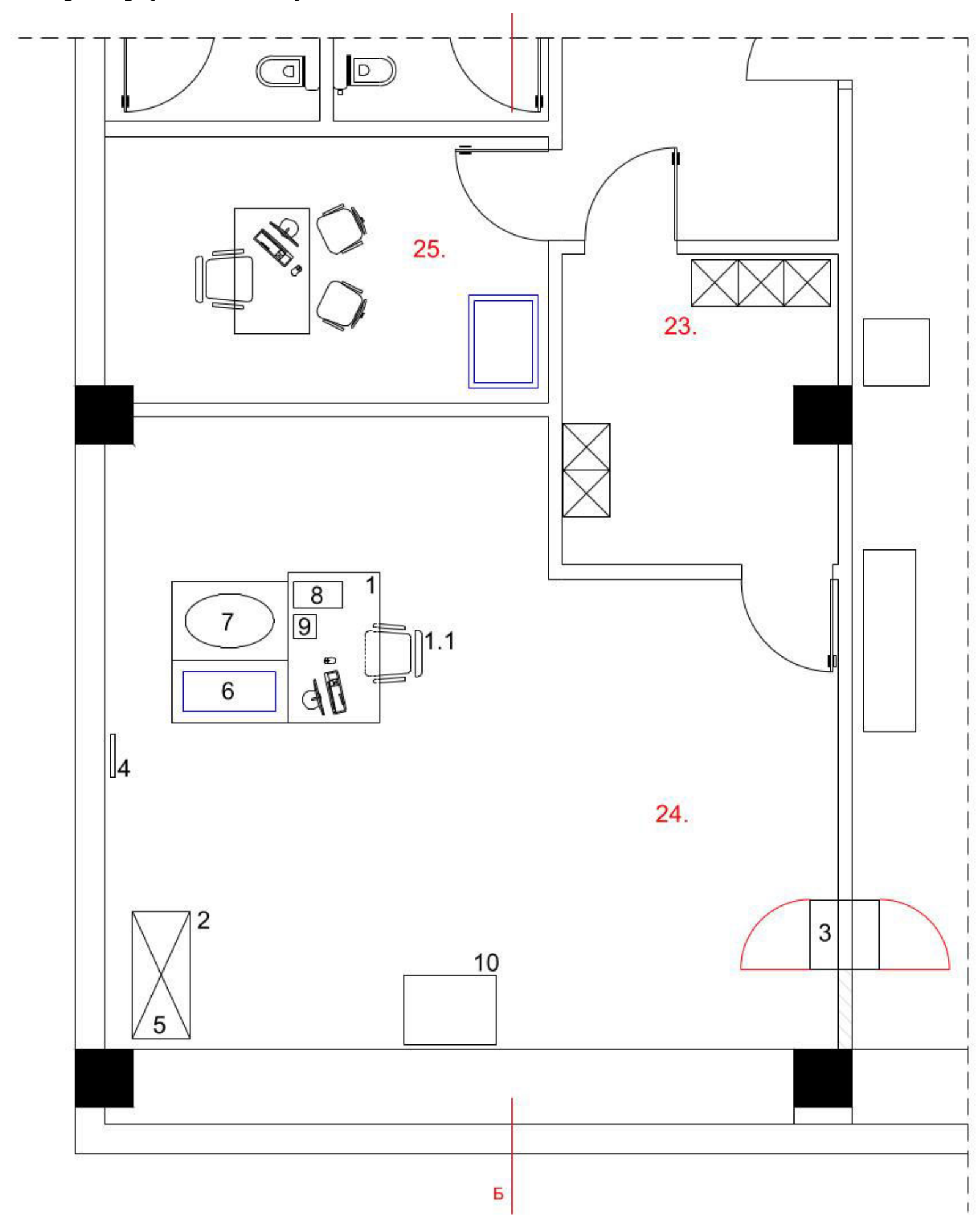

Слика 17: Основа на просторот за изолација на матични клетки 
Применет мебел за опремување на просторот за изолација на матични клетки:

1. работна површина од не'рѓосувачки челик со димезии (120cm x $80 \mathrm{~cm}$ x $80 \mathrm{~cm})$;

1.1 столица од не'рѓосувачки челик ${ }^{25}$;

2. плакар од не'рѓосувачки челик со димензии (110сm x 50cm x 200сm);

3. стерилна кутија за интерен пренос помеѓу лабораторијата и банката.

Применета професионална опрема во просторот за изолација на матични клетки:

1. сонди за притисок, температура и влажност, поврзани со централниот систем за надзор;

2. пренослив систем за броење честици за амбиентален мониторинг на честици во работната средина;

3. кабинет со ламинарен проток (GMP Grade A);

4. bench-top центрифуга;

5. водена бања - JULABO;

6. АХР клеточен сепаратор;

7. фрижидер $+4 /-20^{\circ} \mathrm{C}$.

${ }^{25}$ ANDERSSON, G.B.J., ORTENGREN, R., NACHEMSON, A. and ELFSTROM, G. (1974) Lumbar disc pressure and myoelectric back muscle activity during sitting. I, Studies on an experimental chair, Scandinavian Journal of Rehabilitation Medicine, 3, 104-14. 


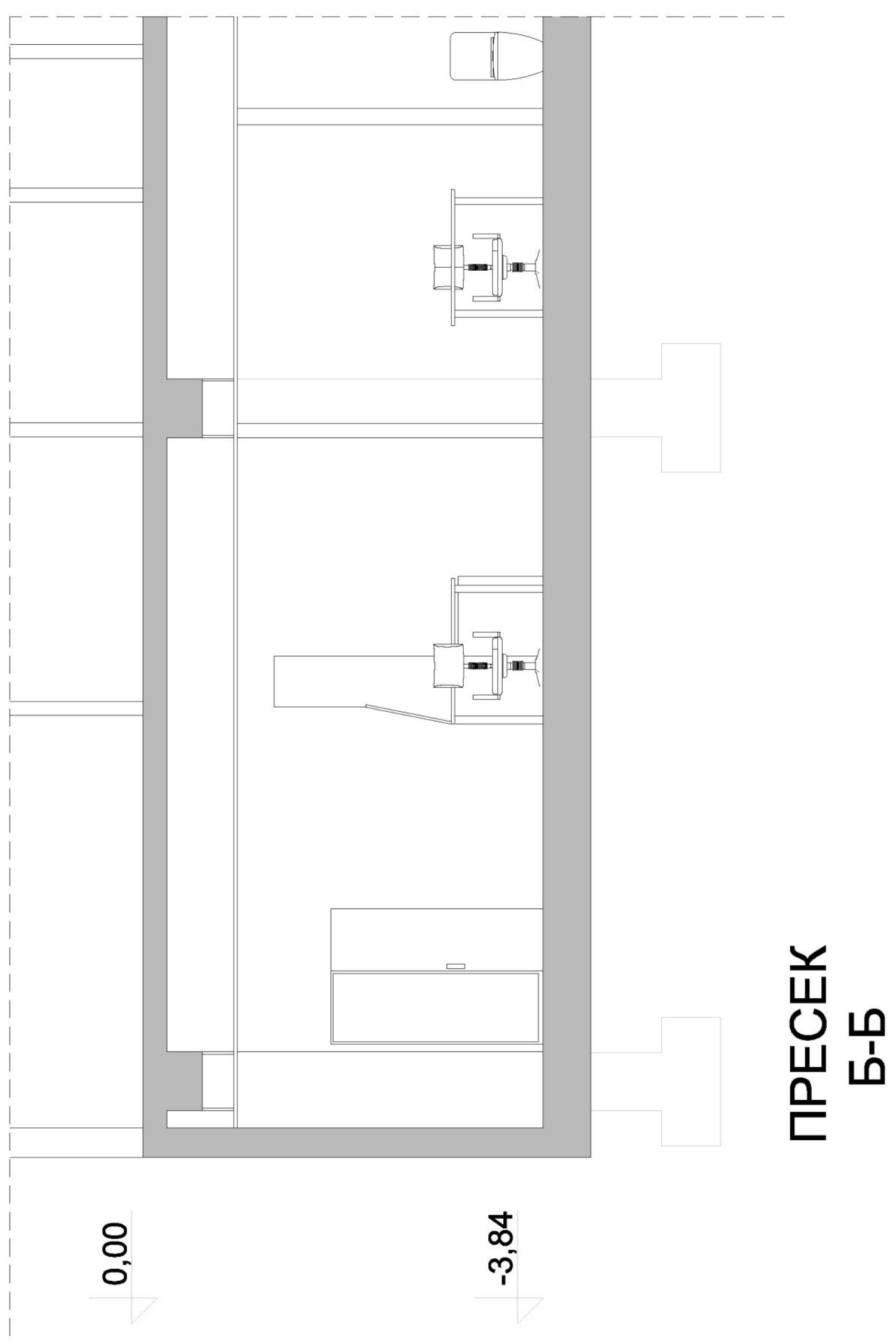

Слика 18: Изглед на просторот за изолација на матични клетки Б-Б 


\subsection{3 Просторија за земање на примероци од крв}

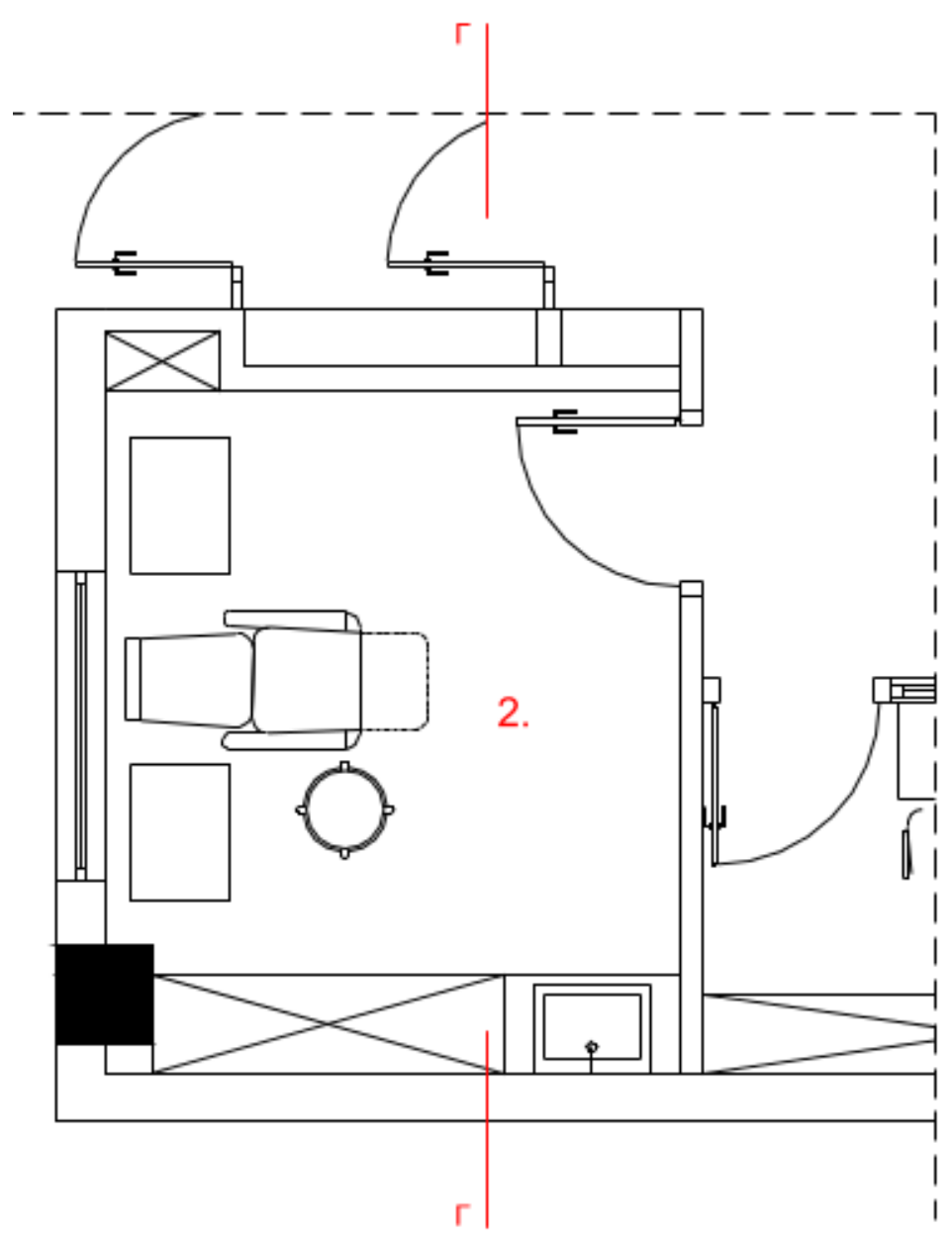

Слика 19: Основа на просторија за земање на примерок од крв

Применет мебел за опремување на просторот за земање примерок од крв:

- две работни површини со фиокари, изработени од плоча од дрвени честици обложена со меламинска фолија со димензии ( $70 \mathrm{~cm}$ x 50cm x 80cm);

- стол;

- полици изработени од плоча од дрвени честици обложена со меламинска фолија со димензии (60сm x $30 \mathrm{~cm}$ x 200сm);

- гардеробер изработен од плоча од дрвени честици обложен со меламинска фолија со димензии (180сm x 50сm x 200сm);

- кујнски елемент со лавабо изработен од плоча од дрвени честици обложена со меламинска фолија со димензии (90сm x 50cm x 80cm). 

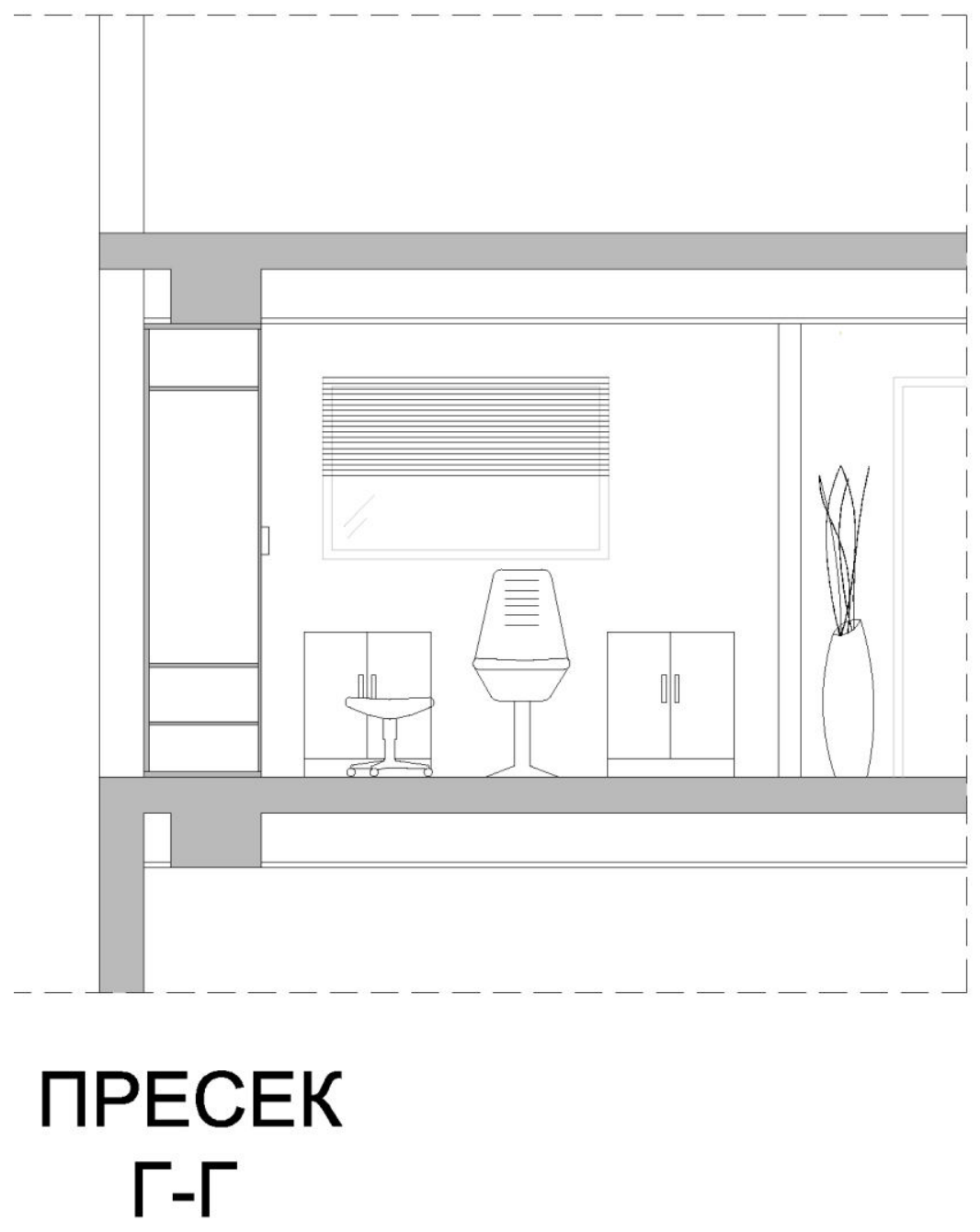

Слика 20: Изглед на просторија за земање на примерок од крв $Г$ - Г 


\subsection{4. Кабинет за имунологија}

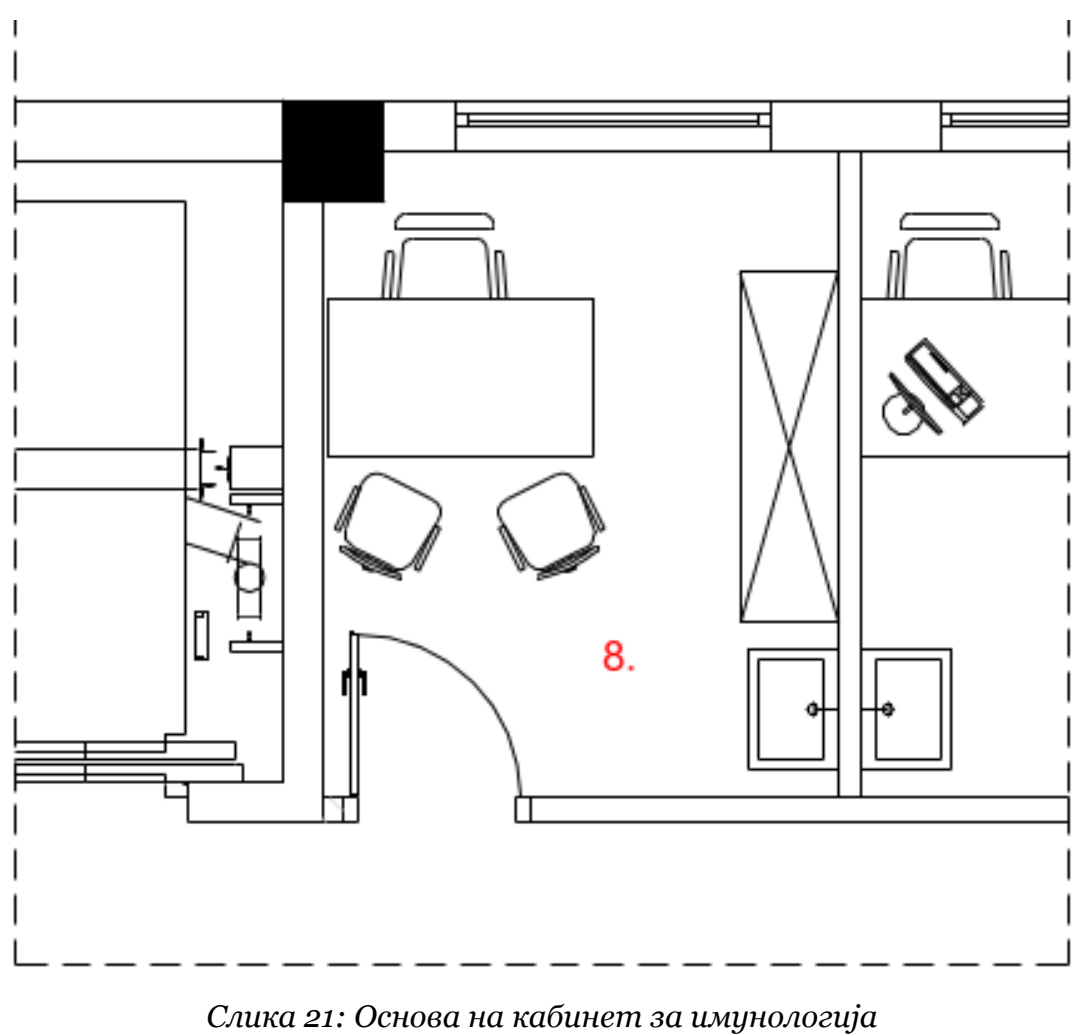

Применет мебел за опремување на просторот за кабинет за имунологија:

- $\quad$ работна маса изработена од плоча од дрвени честици обложена со меламинска фолија со димензии (135 cm x $80 \mathrm{~cm}$ x $75 \mathrm{~cm})$;

- гардеробер изработен од плоча од дрвени честици обложена со меламинска фолија со димензии (180сm x 50cm x 200сm) ;

- кујнски елемент изработен од плоча од дрвени честици обложена со меламинска фолија со димензии (90сm x 50cm) ;

Применета опрема за опремување на просторот за кабинет за имунологија:

- компјутер. 


\subsection{5. Кабинет за молекуларна медицина}

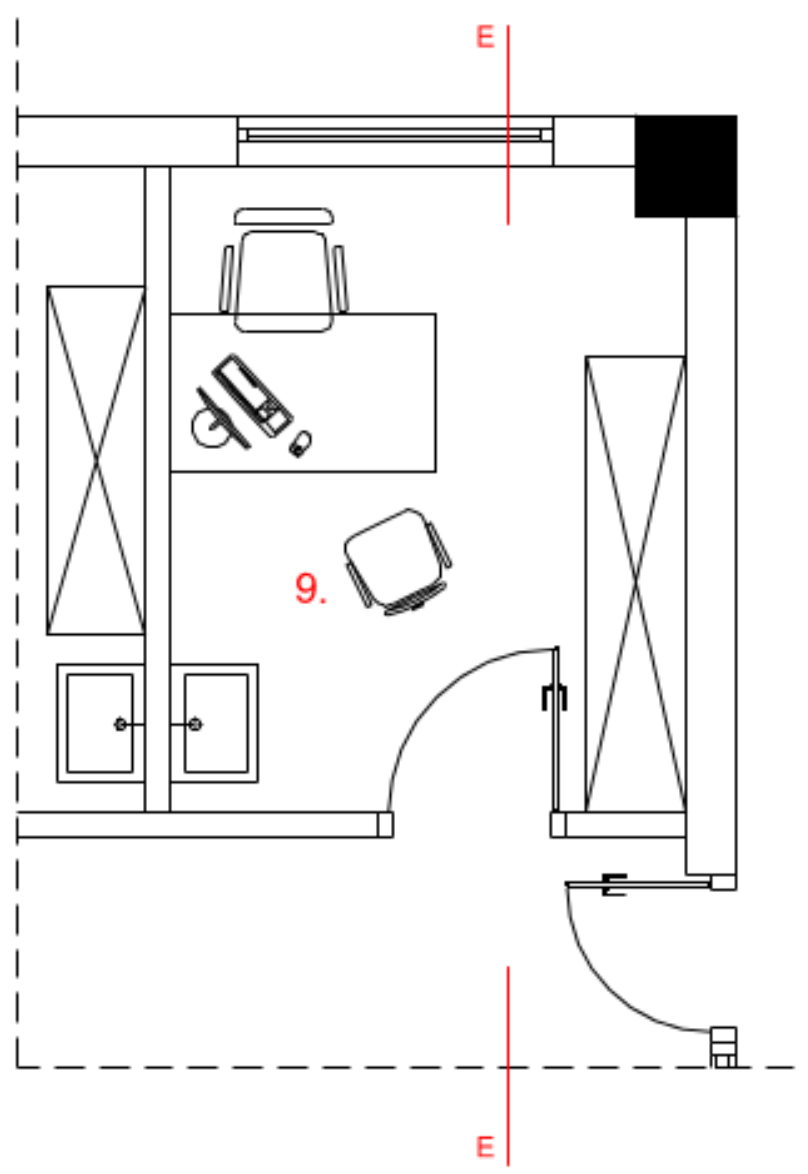

Слика 22: Основа на кабинет за молекуларна медицина

Применет мебел за опремување на просторот за молекуларна медицина:

- работна маса изработена од плоча од дрвени честици обложена со меламинска фолија со димензии $(135 \mathrm{~cm} \text { x } 80 \mathrm{~cm} \text { x } 75 \mathrm{~cm})^{26}$;

- две столици;

- гардеробер изработен од плоча од дрвени честици обложена со меламинска фолија со димензии (230сm x 50cm x 200сm) ;

- $\quad$ кујнски елемент изработен од плоча од дрвени честици обложена со меламинска фолија со димензии (90сm x 50cm x 80cm).

Применета опрема за опремување на просторот за молекуларна медицина:

- компјутер.

${ }^{26}$ GRANDJEAN, E. (1987) The Ergonomics of Computerized Offices, London: Taylor \& Francis. 


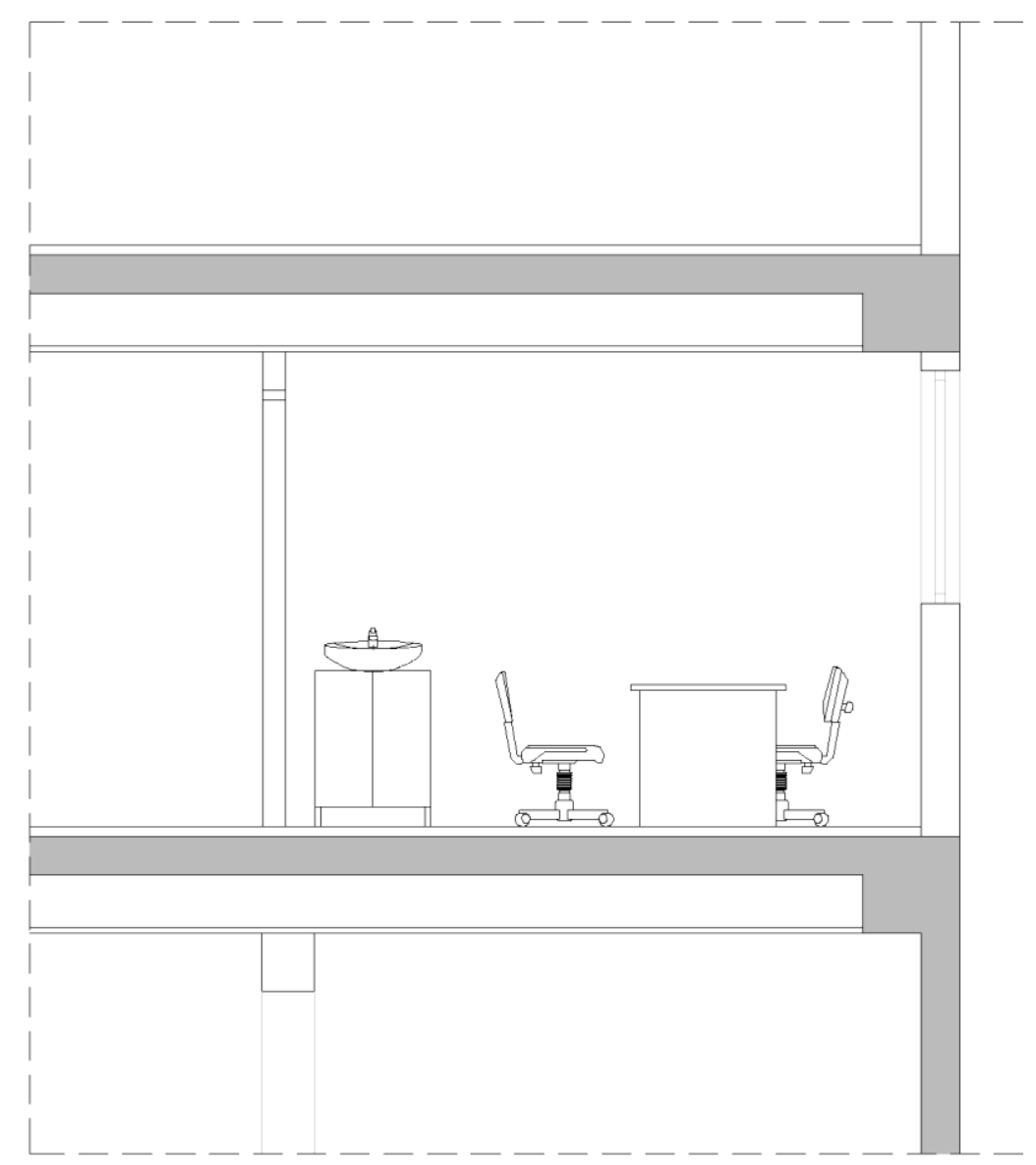

\section{ПPECEK \\ E-E}

Слика 23: Изглед на кабинет за молекуларна медицина E-E 


\subsection{6. Кабинет за хумана генетика}

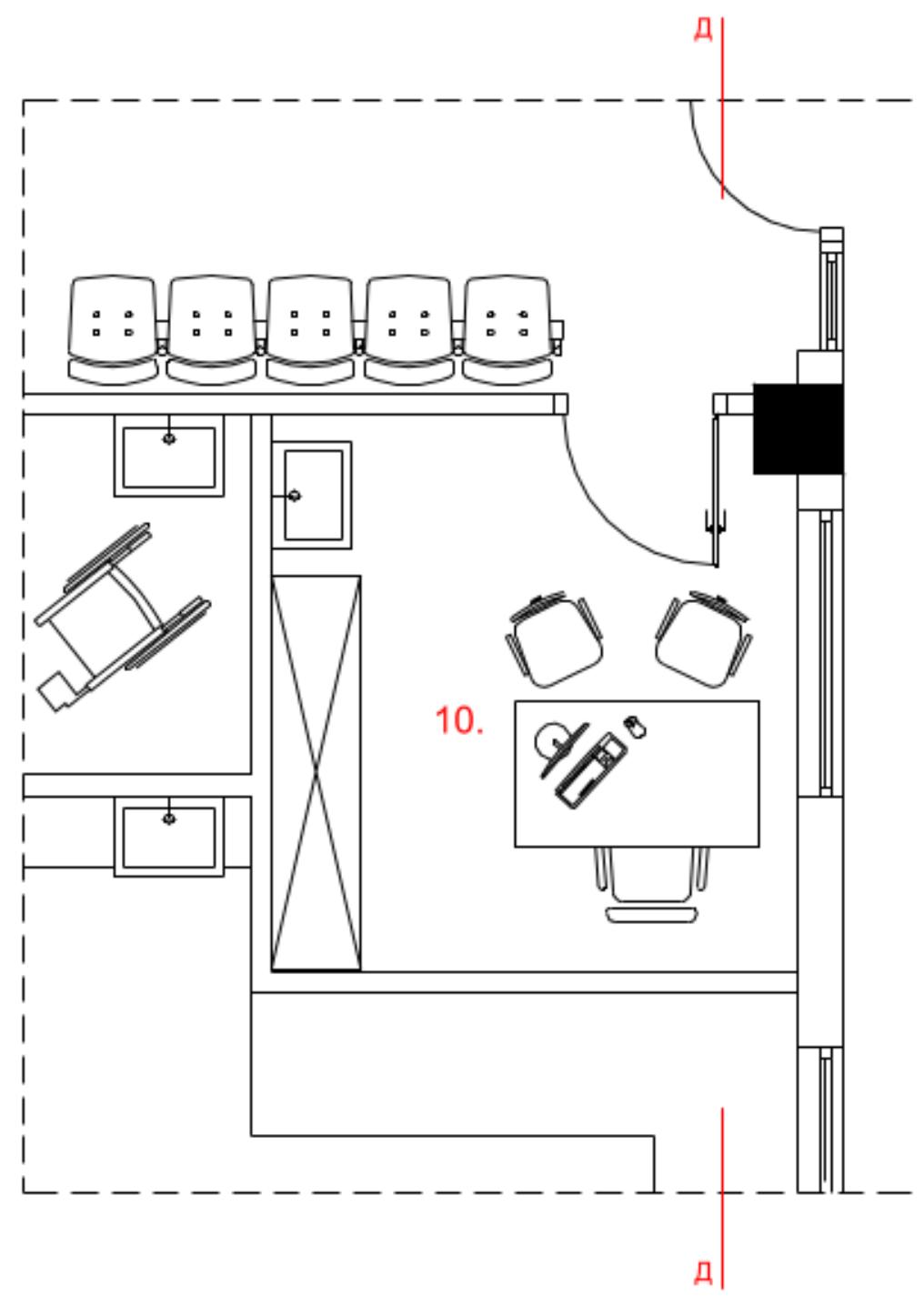

Слика 24: Основа на кабинет за хумана генетика

Применет мебел за опремување на просторот за хумана генетика:

- работна маса изработена од плоча од дрвени честици обложена со меламинска фолија со димензии (135 cm x $80 \mathrm{~cm} \times 75 \mathrm{~cm})$;

- три столици;

- гардеробер изработен од плоча од дрвени честици обложена со меламинска фолија со димензии (230сm x 50cm x 200сm) ;

- $\quad$ кујнски елемент изработен од плоча од дрвени честици обложена со меламинска фолија со димензии (90сm x 50cm x 80cm).

Применета опрема за опремување на просторот за хумана генетика:

- компјутер. 

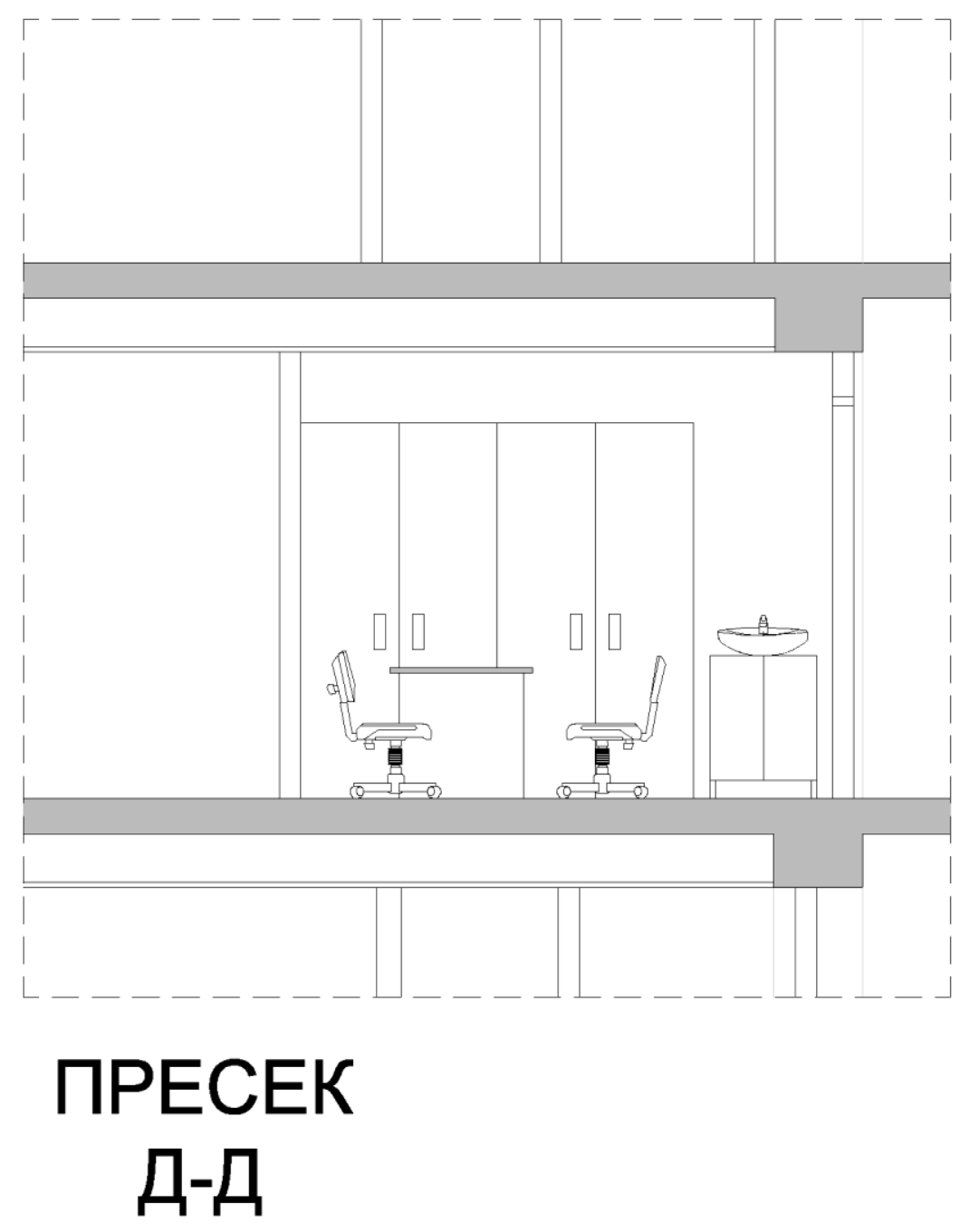

Слика 25: Изглед на кабинет за хумана генетика Д-Д 


\subsection{7. Лабораторија за молекуларна имунологија}

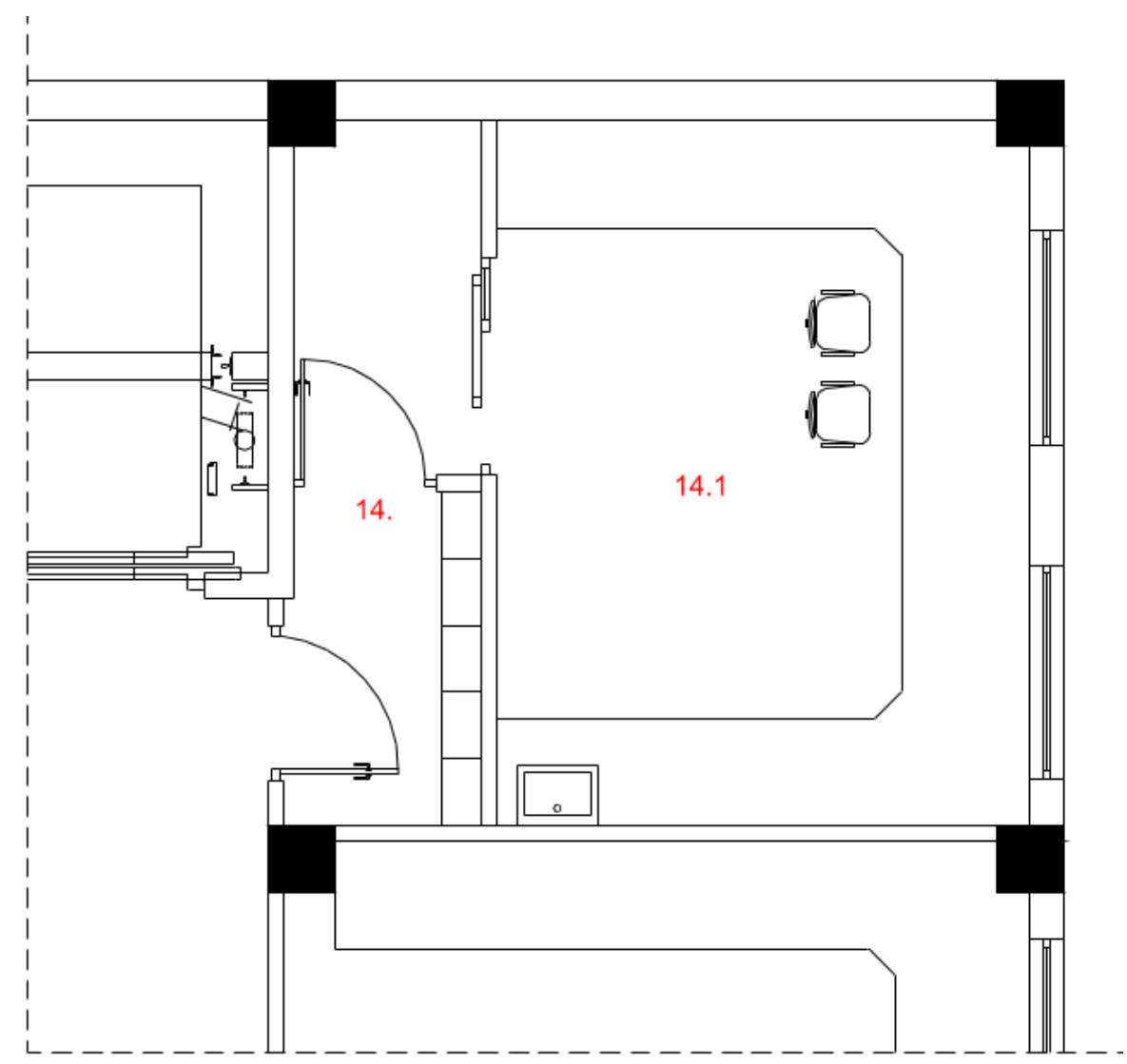

Слика 26: Основа на лабораторија за молекуларна имунологија

Применет мебел за опремување на просторот за молекуларна имунологија:

- работна површина изработена од плоча од дрвени честици посформинг обработена со ламинат (300сm; 350cm; $300 \mathrm{~cm}$ x $80 \mathrm{~cm}$ x 75cm);

- $\quad$ гардеробер - пет парчиња изработени од плоча од дрвени честици обложена со меламинска фолија со димензии (50cm x $30 \mathrm{~cm}$ x $160 \mathrm{~cm})$.

Применета професионална опрема за опремување на просторот за молекуларна имунологија:

- Beckman Coulter MoFlo XDP апарат за сортирање на клетки со голема брзина. 


\subsection{8. Лабораторија за протеини и аутоантитела}

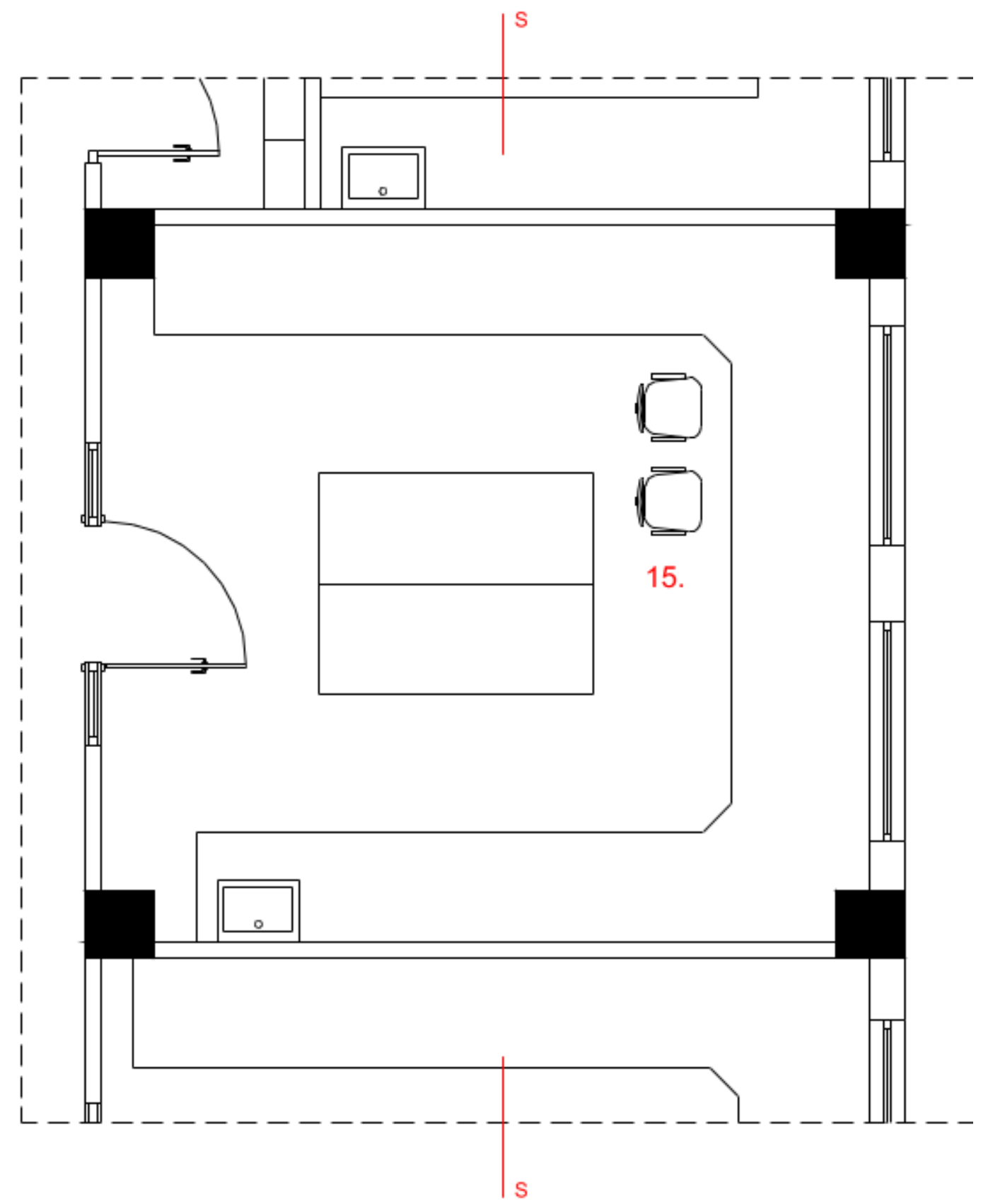

Слика 27: Основа на лабораторија за протеини и аутоантитела

Применет мебел за опремување на лабораторија за протеини и автопротив тела:

- работна површина изработена од плоча од дрвени честици посформинг обработена со ламинат (390сm; 350сm; 420cm x $80 \mathrm{~cm}$ x 75cm);

- $\quad$ работно острово изработено од плоча од дрвени честици посформинг обработена со ламинат $(160 \mathrm{~cm} \text { x } 200 \mathrm{~cm} \text { x } 110 \mathrm{~cm})^{27}$.

\footnotetext{
${ }^{27}$ DAS, B. and GRADY, R.M. (1983) The normal working area in the horizontal plane: a comparative analysis between Farley's and Squires' concepts, Ergonomics, 26, 449-59.
} 
Применета професионална опрема за опремување на лабораторија за протеини и автопротив тела:

- автоматски луминометар - GloMax-Multi.

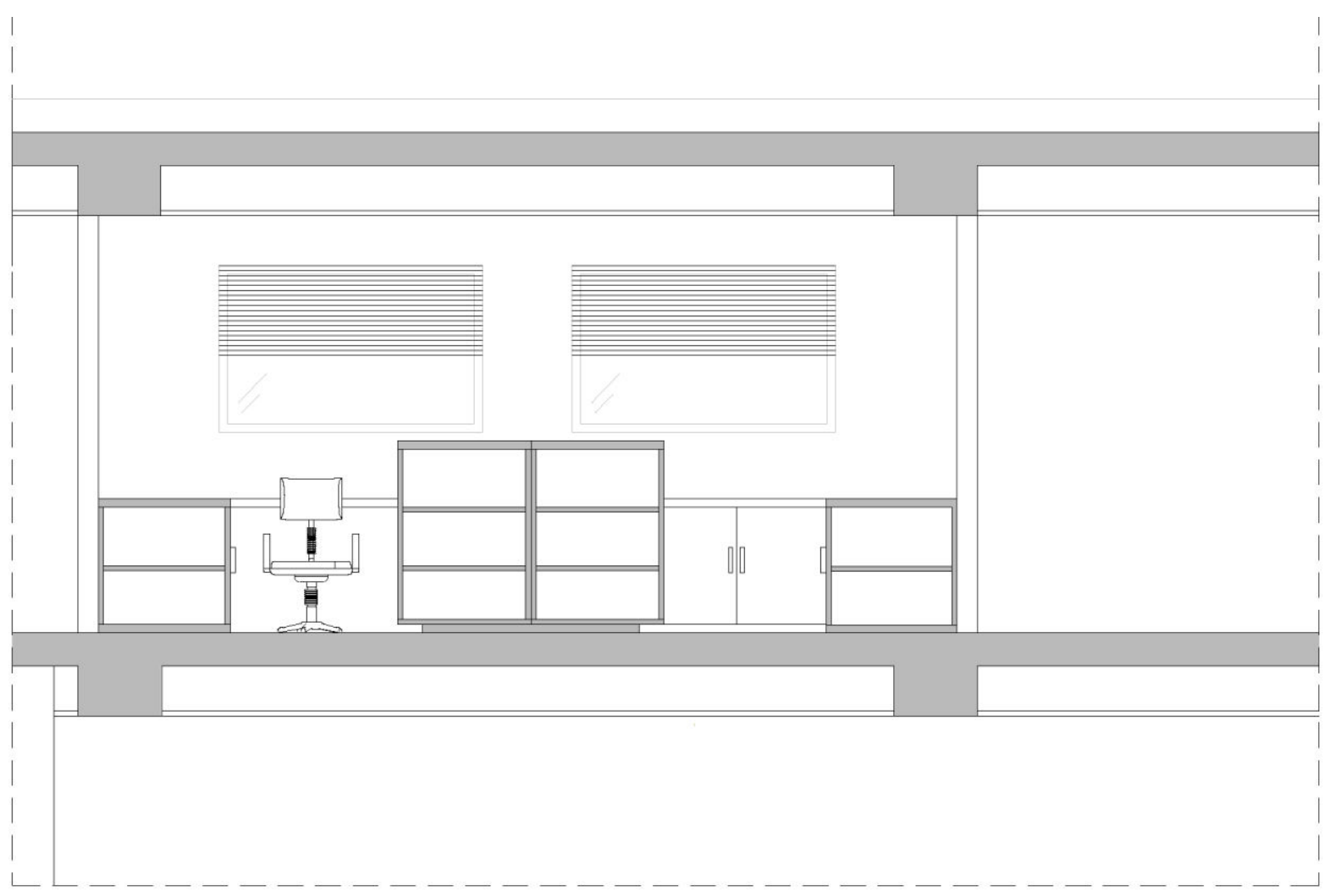

ПPECEK

S-S

Слика 28: Изглед на лабораторија за протеини и автопротив тела $S-S$ 
6.1.9. Лабораторија за алергологија и серолошка имуногенетика

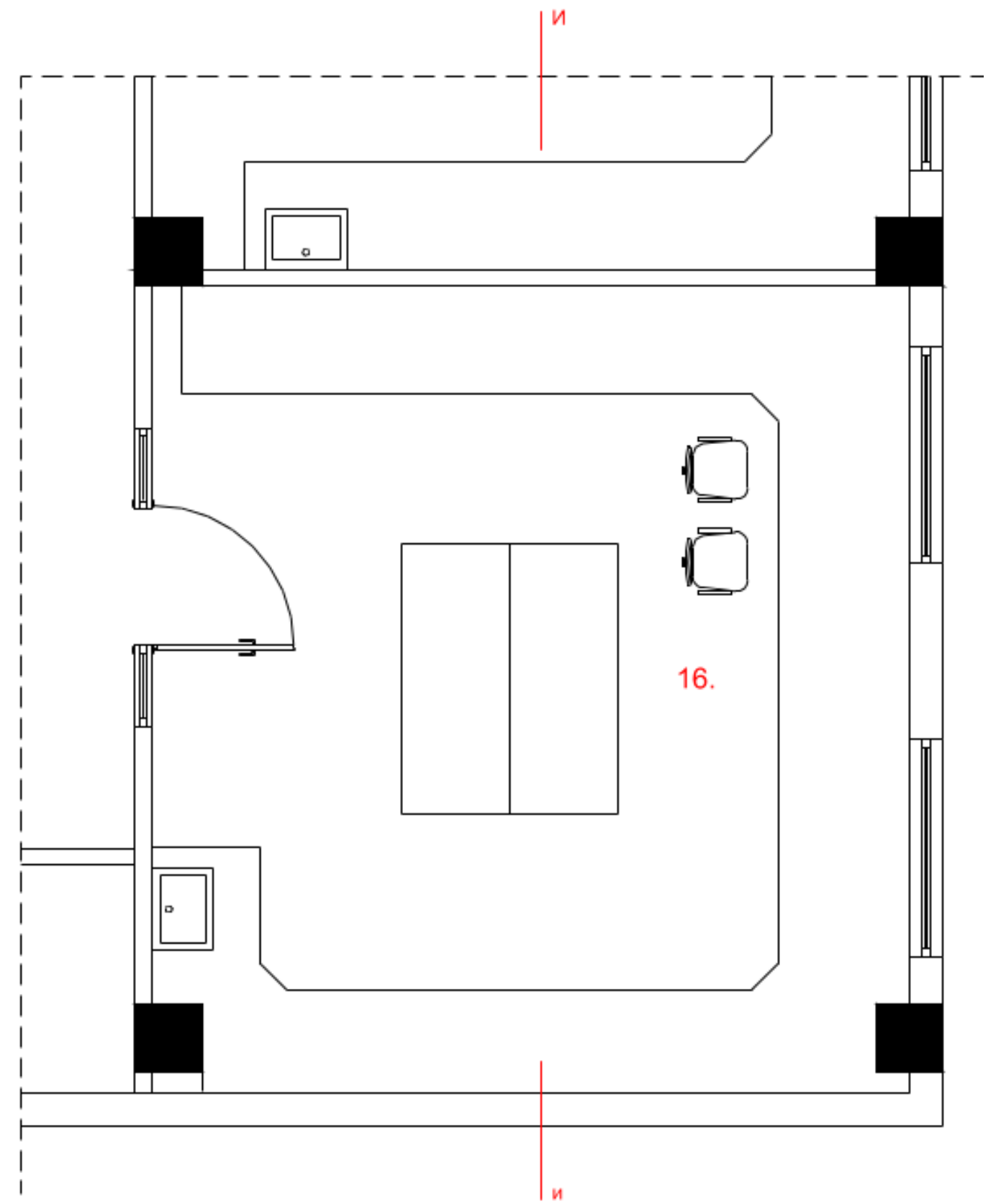

Слика 29: Основа на лабораторија за алергологија и серолошка имуногенетика

Применет мебел за опремување на лабораторија за алергологија и имуногенетика:

- $\quad$ работна површина изработена од плоча од дрвени честици посформинг обработена со ламинат (420cm; 370cm; 370cm x $80 \mathrm{~cm}$ x 75cm);

- работно острово изработено од плоча од дрвени честици посформинг обработена со ламинат (160сm x 200сm x 110cm).

Применета професионална опрема за опремување на лабораторија за алергологија и имуногенетика:

- уред за полимерна верижна реакција во реално време (Real-time PCR). 


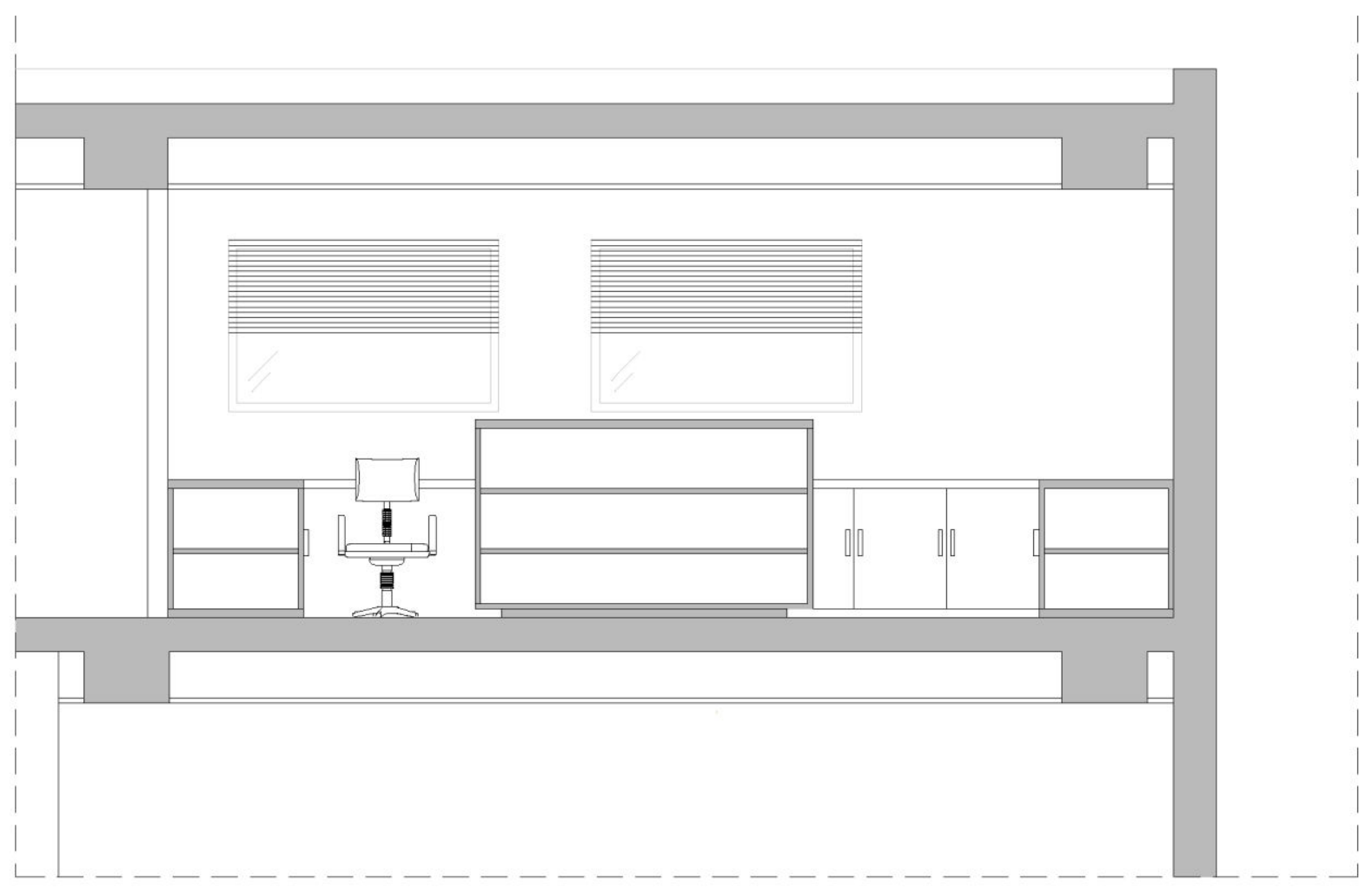

\section{ПРЕСЕК}

Слика зо: Изглед на лабораторија за алергологија и серолошка имуногенетика И-И 
6.1.10. Лабораторија за проточна цитометрија

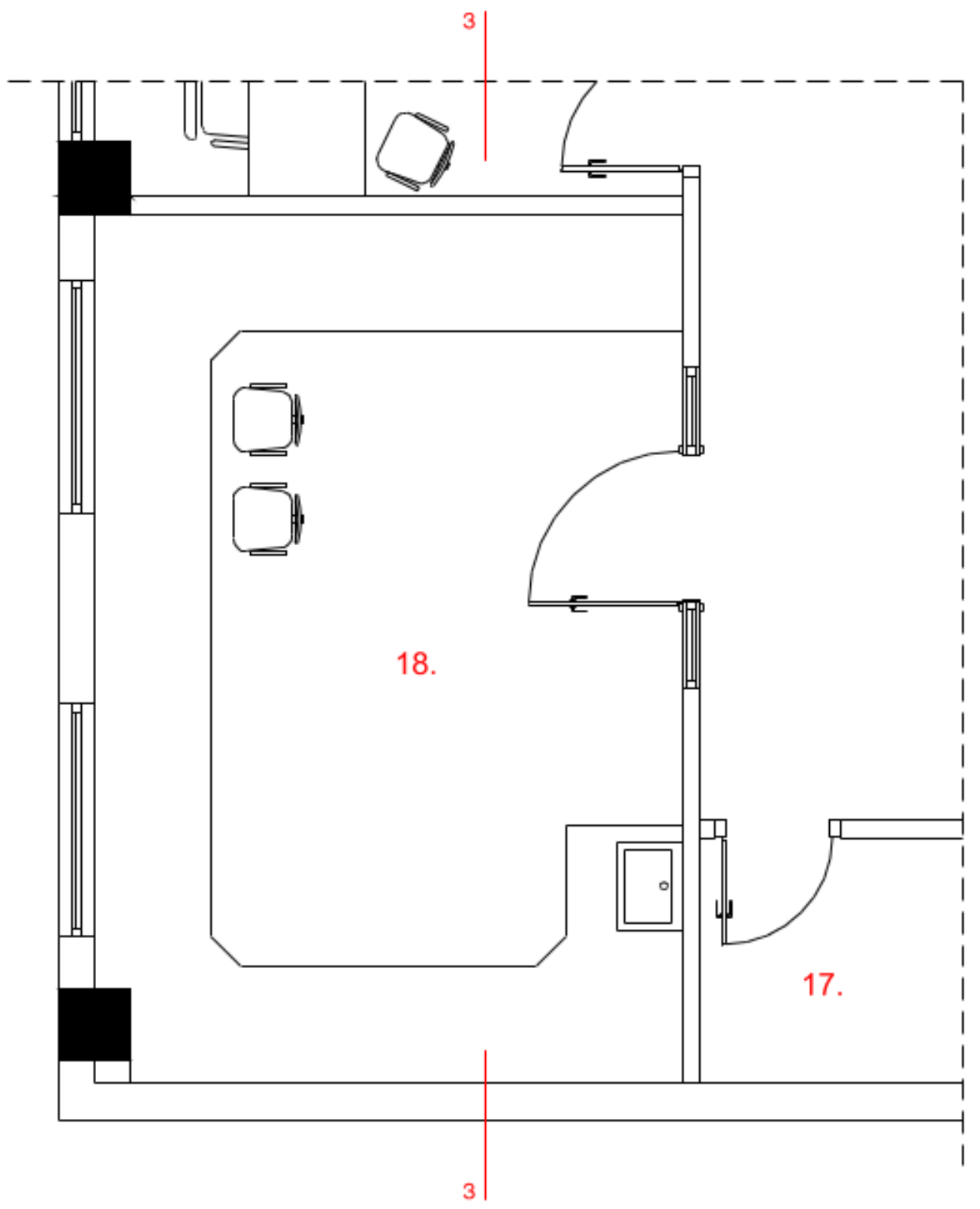

Слика 31: Основа на лабораторија за проточна цитометрија

Применет мебел за опремување на лабораторија проточна цитометрија:

- работна површина изработена од плоча од дрвени честици посформинг обработена со ламинат (420cm; $310 \mathrm{~cm} ; 420 \mathrm{~cm}$ x $80 \mathrm{~cm}$ x $75 \mathrm{~cm}$ ).

Применета професионална опрема за опремување на лабораторија за проточна цитометрија:

- Автоматски ДНК екстрактор (AutoGenFlex STAR). 


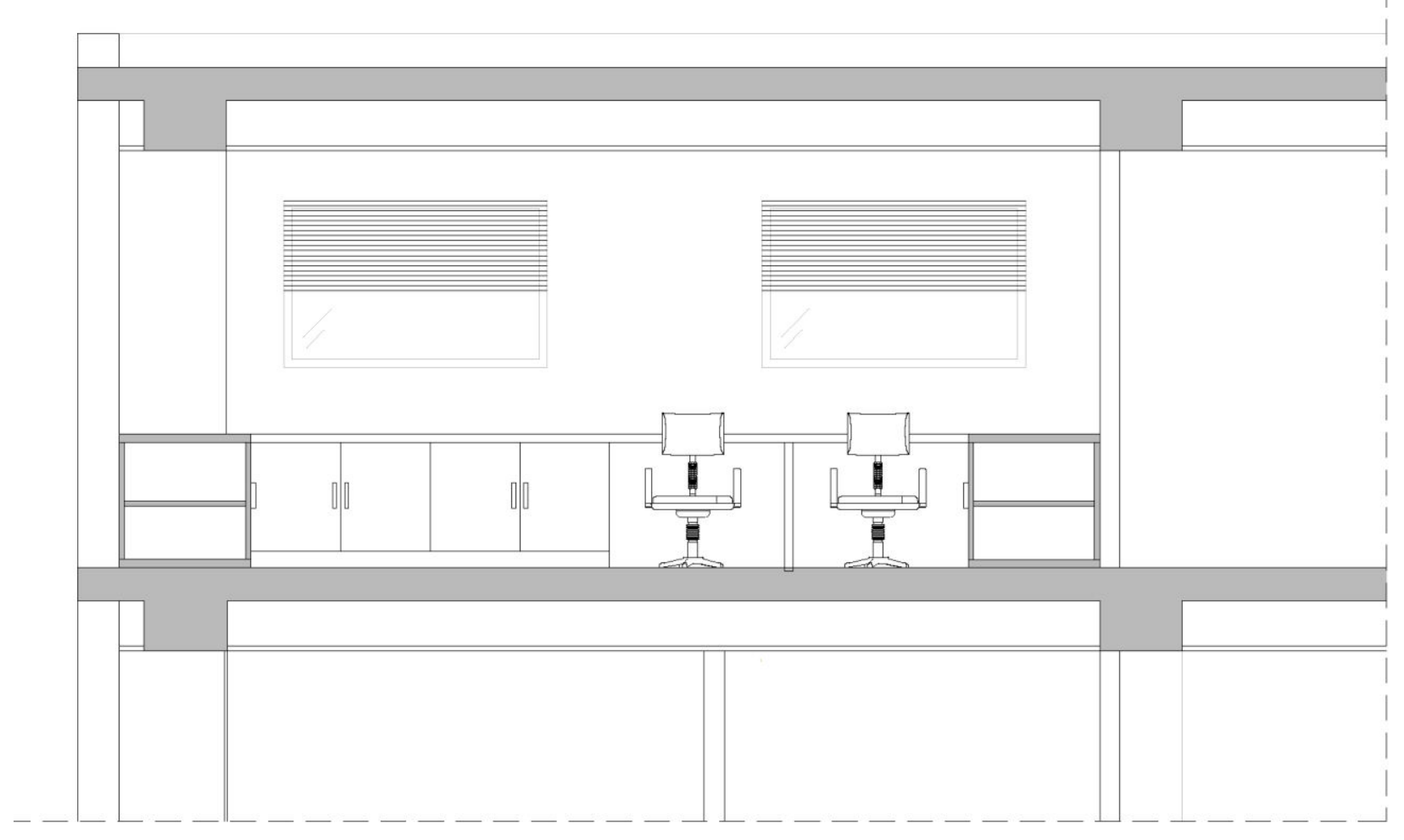

\section{ПРЕСЕК}

\section{3-3}

Слика 32: Изглед на лабораторија за проточна цитометрија 3-3 


\section{2. Анализа на техничка опрема}

\subsection{1. Опремување на просторот за биобанка}

Опремувањето се однесува на следните функционални сегменти:

а) GMP просторија со три дела со позитивен притисок, од кои една лабораторија од околу 28 $\mathrm{m}^{2}$ (GMP Grade C) за манипулација со современите терапевтски производи, комплетирана со соблекувална и средна тампон зона (GMP Grade D и GMP Grade D/C за коридорот), според GMP регулативите.

Просторијата е обезбедена со:

-Систем за греење, вентилација и климатизација, чиј мотор ќе биде поставен надвор од зградата, со ХЕПА филтер, наменет за сите простории, според класификацијата на GMP за простори со позитивен притисок;

-Воздушно ладен килер со аксијални вентилатори и двороторен завоен компресор; -1 систем за надзор, со компјутер и контролен панел, за прием, управување и пренос на сите податоци и аларми, поставен во мала просторија наменета за надзор;

-Сонди за притисок, температура и влажност поставени во трите простории, поврзани со централниот систем за надзор;

-Вградување на ПВЦ подови, зидови и спуштен плафон на висина од 2,70 метри од земја;

-Инсталација на мебел од не'рѓосувачки челик во чисти простории (клупа, маси, столици, полици, плакари);

-Набавка на еден пренослив систем за броење честици за амбиентален мониторинг на честици во работната средина и во кабинетот со ламинарен проток;

-Блокирачки врати заради спречување на контаминација при премин на персоналот; -еден надворешен систем со беџови за влез + еден внатрешен систем со беџови контрола; -Ракување со материјали преку стерилна кутија за интерен пренос помеѓ лабораторијата и биобанката;

-Лабораторијата е снабдена со еден кабинет со ламинарен проток (GMP Grade A), bench-top центрифуга, еден АХР клеточен сепаратор, еден микроскоп и еден фрижидер +4/-20 ${ }^{\circ} \mathrm{C}$.

б) Простор за биобанка од околу $50 \mathrm{~m}^{2}$, сместен во подрум и опремен со следниве елементи: -три оперативни dewar садови MVE Chart за складирање на примероци од крв од папочна врвца во гасна фаза; два dewar сада, од брендот MVE Chart;

-еден Planer замрзнувач за примероци од крв од папочна врвца;

-еден сад под притисок за внатрешно снабдување со течен азот до Planer замрзнувач; 
-еден надворешен резервоар со течен азот со телеметриски систем за следење на работните параметри, со капацитет од 10.000 литри, за снабдување со азот до садовите под притисок преку супер-изолиран вакуумски цевковод со должина од 25 метри;

-два детектори за кислород поставени на 80 cm од подот;

-еден надворешен систем со беџови за влез + еден внатрешен систем со беџови за контрола; -еден систем за надзор, со компјутер и контролен панел, за прием, управување и пренос на сите податоци и аларми, поставен во мала просторија наменета за надзор и контролна табла поставена на влезот од биобанката;

-Систем за видео надзор, поврзан со централниот систем за надзор и рекордер;

-Систем за вентилација со постојана промена на воздухот со капацитет $10 \mathrm{vol} / \mathrm{h}$ во стандардни услови, $25 \mathrm{vol} / \mathrm{h}$ во вонредни услови (при ниска концентрација на кислород);

-една сонда за мерење на температурата и една сонда за мерење на влажноста, поврзани со централниот систем за надзор;

-еден sиден систем за самостојно дишење за итни случаи, сместен надвор од биобанката; -две контролни зидни копчиња за итни случаи (ако не се притисне во следните 5 минути се вклучува безбедносен аларм);

-еден печатач + еден баркод читач за управување со следливоста;

-еден компјутер заради употреба на печатачот;

-еден $-85^{\circ} \mathrm{C}$ замрзнувач, опремен со запишувач на податоци и поддршка од $\mathrm{CO}_{2}$ за снабдување во итни случаи;

-два dewar сада (еден за карантин) за транспорт на примероци од крв од папочната врвца во азотна гасна фаза.

\subsubsection{GMP просторија}

GMP просториите се утврдени како серија на простории каде се врши манипулација со клетки добиени од човек и затоа треба да се осигура квалитетот и безбедноста на производите. Во просториите со контролирана контаминација, сите изложени површини ( намали акумулацијата на честици или микроорганизми и лесно и ефикасно да се овозможи употребата на детергенти и соодветни средства за дезинфекција.

Во просторите мора да се избегнуваат агли и тешко достапни вдлабнатини и полици, со цел да се намали акумулирањето на прав и да се олесни чистењето. Вратите мора да се дизајнирани на начин за да се избегне присуството на шуплини; не се дозволени шиберврати. Спуштените плафони мора да бидат изолирани за да се избегне контаминација од просторот над нив. Цевките, каналите, системите за осветлување, системите за вентилација и климатизација мора да се дизајнирани и поставени така што ќе се избегнат површини 
тешки за чистење. Објектот треба да овозможи лесна достапност до уредите и системите за одржување. Не е дозволено инсталирање на мијалници и одводи во внатрешните простории класифицирани како Grade B. Влезовите кои ги опкружуваат херметички затворените оддели не смеат да бидат отворени истовремено: тоа мора да биде систем со аудио-визуелно предупредување (пр. уреди од типот на семафори) за да се регулира пристапот до заштитените простори. Пристапот во регулираните средини мора да биде преку врати со електромеханичка сигурносна брава со алфа нумерички код за отклучување или магнетна карта, копче за отворање во итни случаи лоцирано во внатрешните простории класифицирани како Grade B, интерфони поврзани со просторот Grade C и Grade D.

Овој простор ќе биде дизајниран така што ќе ги има следниве карактеристики:

-Систем за греење, вентилација и климатизација и единица за пречистување на воздух, поставени во специјално наменет технички простор, со цел одржување на потребните притисоци во секоја соба, со цел да се намали ризикот од контаминација;

-пристапот ќе биде ограничен само на овластен персонал кој ќе има посебен беџ; -зависно од поставените процедури, да се следи притисокот во просториите со цел да се избегне појава на потенцијално загадувачки струи штетни за операторот и/или примерокот; -ПВЦ подови лесни за чистење, подвижни зидови со пластичен ламинат и алуминиумска рамка, спојка на пресекот на два елементи (отсуство на пукнатини кои се тешки за дезинфекција според GMP) и спуштени плафони во силиконски модули, чии детали ќе бидат дадени во следниот параграф;

-Секоја поединечна просторија во лабораторијата мора да биде снабдена со единствен независен систем за одвод на отпаден воздух;

-Секој кабинет со ламинарен воздушен проток мора да биде поврзан со аспиратор и да биде спроведен преку таванот во системот за греење, вентилација и климатизација;

-Мора да има достапни линии за комуникација помеѓ лабораторијата и надворешноста (интерфон или спикерфон);

Средините со контролирана контаминација, вклучувајќи ги и дополнителните простории, мора да бидат дизајнирани според барањата на GMP, со цел да се гарантира специфично ниво на чистота во услови на „неактивност“ и „активност“, според следниве дефиниции:

а) „неактивност“: кога објектите и системите се целосно инсталирани и работат, но во отсуство на оператори;

б) „активност“: кога објектите и системите се во режим на работа, во присуство на оператори. 
Вградената опрема мора:

1) да биде во согласност со Директива 93/42/EЕЗ и означена со СE;

2) да има прирачник на англиски јазик;

3) да поседува сертификат за калибрација и етикета на уредите која укажува на датумот на истекување на рокот.

\begin{tabular}{|l|l|l|}
\hline GMP Grade & Температура & Влажност \\
\hline B & $19 \pm 1^{\circ} \mathrm{C}$ & $50 \pm 10 \%$ \\
\hline $\mathrm{C}$ & $20 \pm 2^{\circ} \mathrm{C}$ & $50 \pm 10 \%$ \\
\hline $\mathrm{D}$ & $20 \pm 2^{\circ} \mathrm{C}$ & $50 \pm 10 \%$ \\
\hline
\end{tabular}

Табела 3: Влажност и температура

\subsubsection{1 Системски уред за мерење на честици}

Според регулативите за GMP, системот за мерење на честици мора да биде достапен за периодично испитување на средината во уредот Grade A (кабинет со ламинарен воздушен проток) и во околните средини на Grade C.

За зоната А, следењето на честиците треба да се изведува во текот на целото времетраење на критичната обработка, вклучувајќи монтажа на опрема, освен онаму каде е докажано присуство на загадувачи во процесот кој би го оштетил системот за броење на честици или би претставувал опасност, пр. живи организми и радиолошки опасности. Во такви случаи пред монтажата се прави мониторинг и проценка на експозицијата на штетноста, како и мониторинг на симулирани постапки. Зоната А треба да се следи со таква фреквенција и со соодветна големина на примерок, така што сите интервенции, краткотрајни настани и дефекти на системот ќе бидат забележани и ќе активираат аларми при надминување на дозволените вредности. Прифатено е дека не е секогаш можно да се прикажат ниски нивоа од $\geq 5,0 \mu \mathrm{m}$ честици во моментот на полнење, поради генерирање на честици или капки од самиот производ.

Се препорачува да се користи сличен систем за зоните $\mathrm{B}$, иако може да се намали фреквенцијата на испитување. Важноста на системот за следење на честици треба да се одреди според ефикасноста на сегрегацијата помеѓ соседните зони на А и В. Зоната В треба да се следи со таква фреквенција и со соодветна големина на примерок, така што сите 
промени во нивото на контаминација и дефекти на системот ќе бидат забележани и ќе активираат аларми при надминување на дозволените вредности.

AeroTrakTM преносливи системи за броење за честици

Модели 9350 и 9550

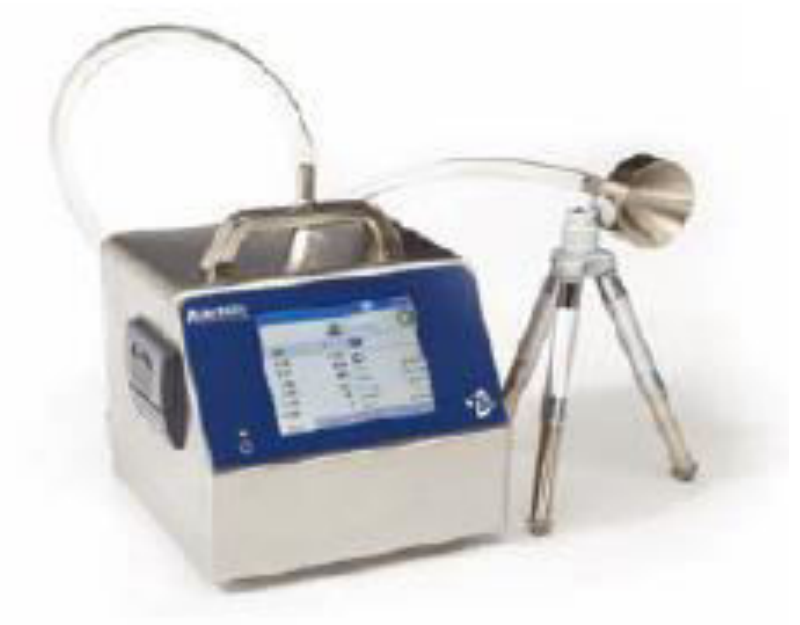

Слика 33: Пренослив систем за броење на честици

TSI AeroTrakTM 9350 и 9550 преносливите системи за броење на честици нудат разновидност и својства кои се најдобри во класата. Тие нудат проток од $50 \mathrm{l} / \mathrm{min}$ со 0,3 или 0,5 $\mu \mathrm{m}$ чувствителност. Исполнува ISO 14644-1 и сертификати на ЕУ за простории со GMP, со испитување на еден $\mathrm{m}^{3}$ воздух за само 20 минути. Компатибилен со прецизни вентилациски сонди на TSI кои мерат воздушна брзина/температура.

Овие системи за броење на честици може да генерираат известувања за исполнување/неисполнување на ISO 14644-1, EУ GMP Анекс 1 и FS209Е. Овие производи може да се употребат како самостојни системи за броење на честици или интегрирани во системот за следење на просториите како PMS 5 на TSI.

И двата модели 9350 и 9550 ги почитуваат сите строги барања предвидени во ISO 21501-4. Овие системи за броење на честици се калибрирани со PSL сфери користејќи TSI класификатор и систем за броење на честици. Со стандардна двегодишна гаранција и долгорочен углед за висок квалитет на TSI, единствен по своите карактеристики на пазарот денес. 


\subsubsection{2 Помошни уреди}

а) Кабинет со ламинарен воздушен проток

Кабинетот со ламинарен воздушен проток е класа II биохазард кабинет, направен за сеопфатна заштита на операторот, производот и средината.

Аспираторот, тип А и В3, има отвор однапред, стерилен ламинарен вертикален воздушен проток од класа 100 (стандардни сојузни правила) во рамките на кабината и ХЕПА филтер.

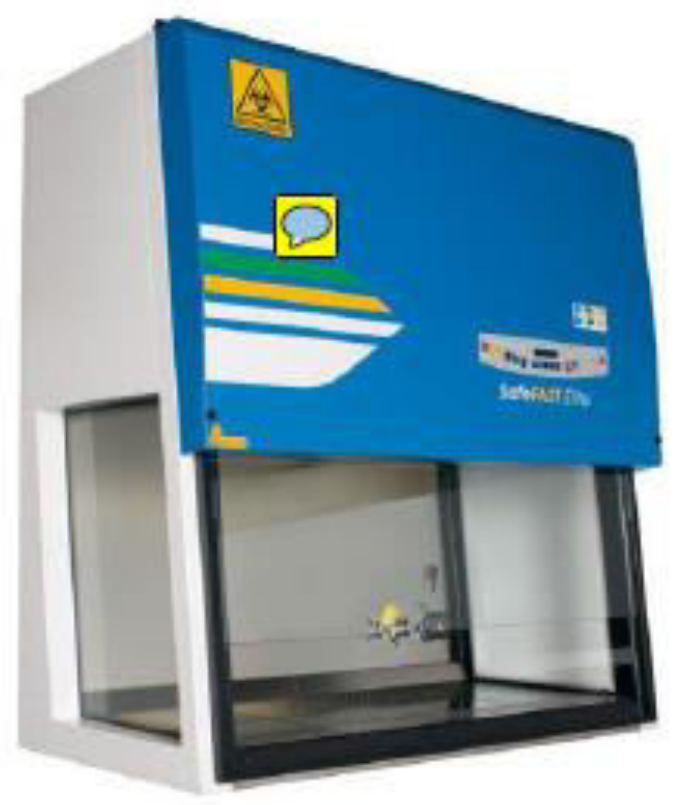

Слика 34: Кабинет со ламинарен воздушен проток

б) bench-top центрифуга

Thermo Scientific Heraeus Cryofuge 550оi - центрифуги за обработка на смрзната крв 


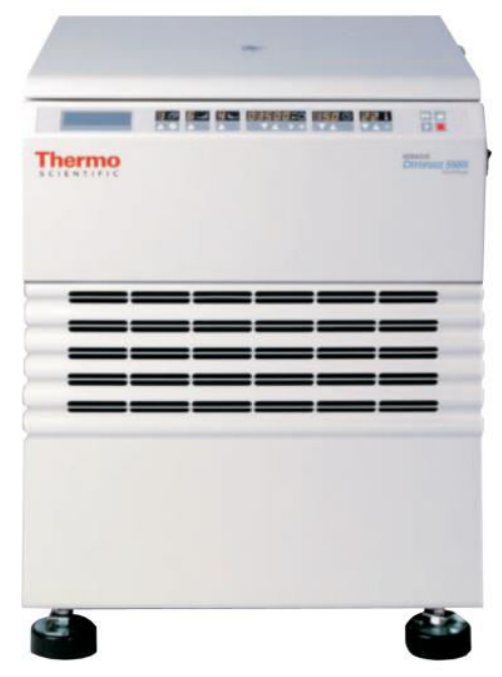

Слика 35: Центрифуга за крв

Thermo Scientific Heraeus Cryofuge 550оі нуди оптимален капацитет за обработка на единици крв со мала и средна големина. Heraeus Cryofuge 550oi може да центрифугира до 8 кеси крв, со различни форми - вклучувајќи 5 кеси по $500 \mathrm{ml}$ со линиски филтри. Покрај тоа, постигнува поголем капацитет од повисоки гравитациски сили и капацитети за сите познати начини на земање крв и клинички епрувети.

в) $+4 /-20^{\circ} \mathrm{C}$ фрижидер- банка за крв

MPR SeriesTM Фрижидер за фармацевтски производи со замрзнувач MPR-414F

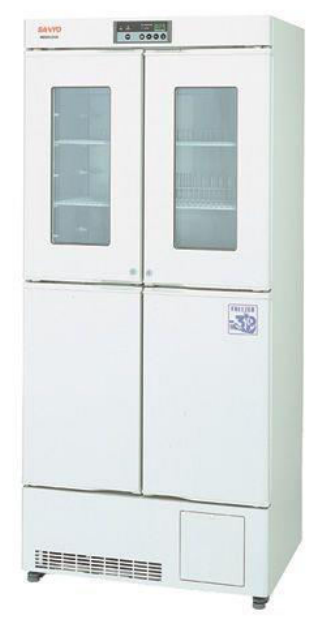

Слика 36: Фрижидер за чување на клетки од крв 
Фрижидерите за фармацевтски производи со замрзнувач SANYO MPR Series го комбинираат замрзнувањето со високи перформанси, контролата и системите за аларм/следење со рентабилен дизајн на кабинет кој е енергетски ефикасен. За една единица со двојна температурна зона потребен е минимален простор. Дизајнот со две врати ја намалува загубата на воздух за време на отворање на вратата.

г) $-85^{\circ} \mathrm{C}$ механички замрзнувач (се инсталира во просторот за биобанка)

MDF-U3386S

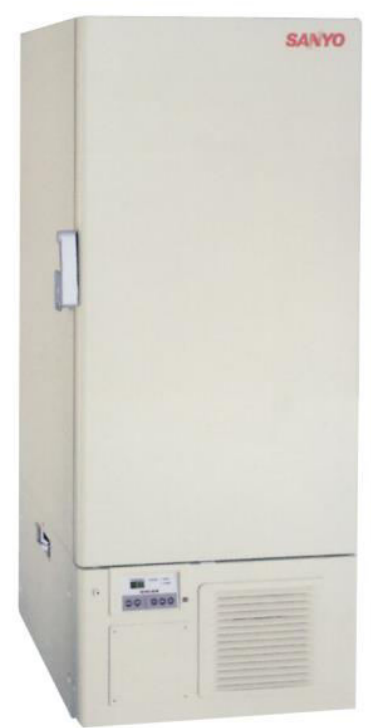

Слика 37: Механички замрзнувач за клетки

д) АХР- платформа за сепарација на матични клетки

Иновативната платформа AXPTM AutoXpressTM дефинира нов стандард за одвојување и зачувување на матичните клетки од папочна врвца. Тоа претставува автоматизиран, целосно затворен, стерилен систем кој го намалува волуменот на крвта од папочната врвца на волумен дефиниран од корисникот за 30 минути, притоа задржувајќи над 97\% од мононуклеарните клетки (MNC - mononuclear cell). AXP платформата која има сопствено напојување и е контролирана од микропроцесор, содржи оптички сензори за контрола на проток кои постигнуваат прецизна сепарација. 


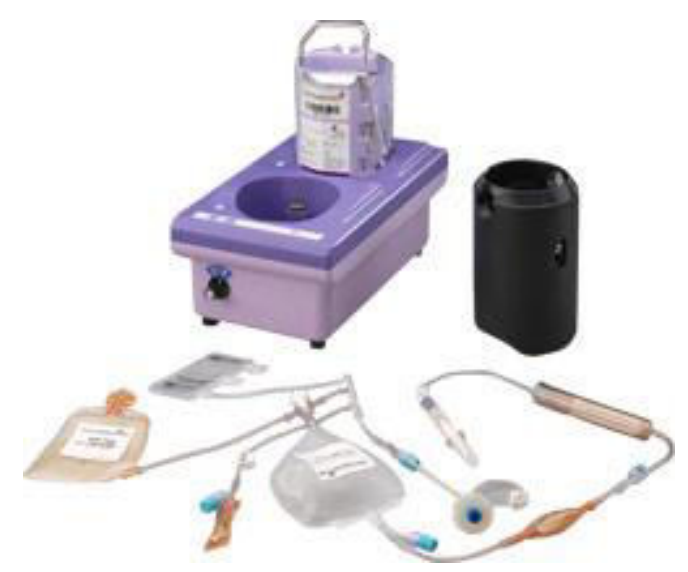

Слика 38: Платформа за сепарација на матични клетки

\subsection{3. Биобанка}

Биобанките конципирани според најсовремените европски технолошки стандарди, овозможуваат долготрајна криопрезервација на биолошки примероци во контејнери со автоматско полнење, регулирани, следени и снимени од страна на софтвер, со следење на сите интервенции, аларми и оперативни фази.

Пренесувањето на сигналите од системот за супервизија овозможува увид на работните карактеристики и алармите до сите овластени лица. Безбедноста на персоналот исто така е загарантирана со употреба на детектори за концентрација на кислород во рамките на дозволените вредности: ако процентот падне под дозволената вредност, веднаш се испраќа алармен сигнал, со цел активирање на процедури за повторно воспоставување на нормални работни услови.

\subsubsection{1 Снабдување со течен азот - Надворешен вертикален резервоар}

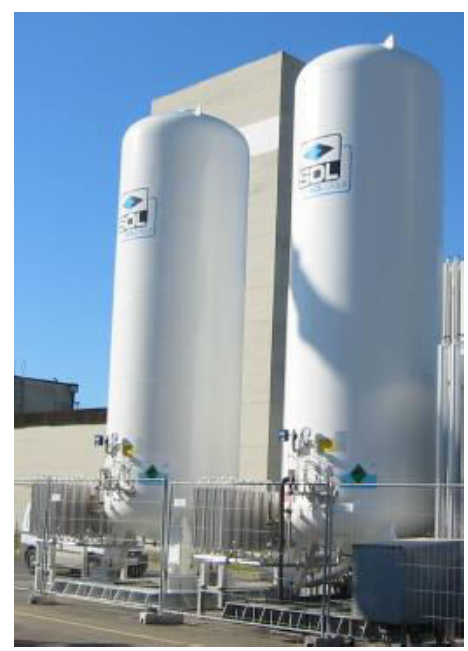

Слика 39: Надворешен резервоар за складирање на течен азот 
Поставување на еден резервоар за складирање на течен азот и конструкција на соодветен вакуумски цевковод, како што е наведено подолу.

Криогенските резервоари служат за складирање на криоген течен гас (азот) и за негова испорака при постојан притисок. Резервоарот се состои од двоен сад: внатрешност од не'рѓосувачки челик која содржи течен азот, дизајниран да издржи внатрешен притисок и надворешност од јаглероден челик дизајниран да издржи надворешен притисок.

Посебен систем за поддршка ја држи конструкцијата во централна позиција. Празнината е исполнета со незапалив изолационен материјал во прав, перлит (вулкански

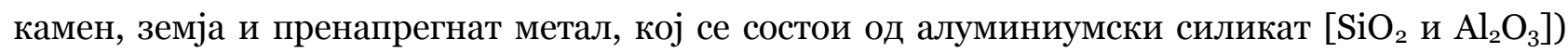
кој се одржува под висок вакуум со цел да се зголеми степенот на термичка изолација на внатрешниот контејнер. Во таа смисла, тие се монтирани на надворешните вентили за создавање вакуум во просторот, користејќи вакуумска пумпа и преку контрола на вакуумската вредност.

Изолацијата не бара одржување подолг временски период.

Загубата на вакуумот го нарушува правилното функционирање на криогенскиот резервоар. Резервоарот е опремен со цевки, вентили, уреди за контрола и безбедност и мерни инструменти. На горниот дел од надворешниот сад се наоѓa безбедносен диск (Safety disc $\mathrm{SD)}$ за да се избегне, во случај на истекување од внатрешниот контејнер и цевките, прекумерен притисок во внатрешноста.

Одржувањето на работниот притисок внатре во резервоарот е целосно автоматско, благодарение на прилагодувањето, направено со помош на економајзер и менувач на брзини (автоматско управуваните вентили со сет од параметри кои може да се прилагодат).

\subsubsection{2 Систем за снабдување со течен азот}

Садовите за криопрезервација мора да бидат снабдени со течен азот, кој се снабдува од надворешни резервоари со вакуумски изолиран цевководен систем.

Во оваа студија е разгледана инсталацијата на вакуумски изолиран цевковод: надворешниот криогенски резервоар ќе биде поставен веднаш до биобанката, на безбеден и ограден простор, заштитен од пристап од страна на неовластени лица.

Употребата на вакуумски изолиран цевковод овозможува безбедно снабдување со течен азот до криогенската опрема и оптимизација на процесот на трансфер благодарение на материјалот со висок квалитет кој се користи за негова реализација. 
Вакуумскиот цевковод е направен од две концентрични цевки од тврд не’рѓосувачки челик AISI 304: внатрешна со номинален дијаметар од $15 \mathrm{~mm}$, обезбедува проток на течен азот, надворешна со дијаметар од 60 - $70 \mathrm{~mm}$ и е вакуумски изолирана за да обезбеди одржување на капацитетот на замрзнување. Меѓу двете цевки постои повеќеслојна супер изолација.

Цевоводот е исто така составен од аксијален компензатор, со што се избегнуваат проблеми со експанзијата што се појавува како резултат на топлотниот ефект и од неколку споеви што се употребуваат за производство на вакуум (10 $\left.{ }^{-3} \mathrm{mbars}\right)$ и се врска до сигурносните вентили.

Како што веќе истакнавме, топлотната дисперзија е практично нула благодарејќи на повеќе слојната супер изолација поставена меѓу двете цевки.

Цевководот има неограничено траење, а одржувањето практички и не е потребно благодарение на херметичкиот вакуум.

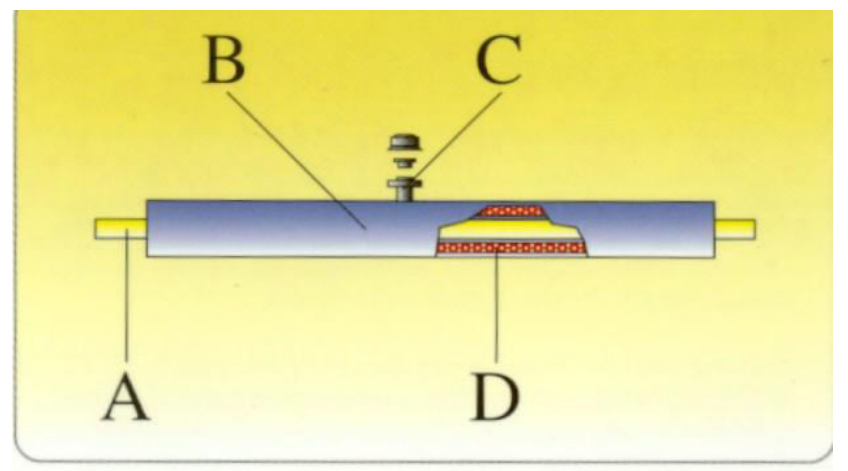

Слика 4о: Шема на вакуумски цевковод. Внатрешна цевка (А); Надворешна цевка (В); Приклучок за производство на вакуум и безбедносен вентил (C); Додадена повеќеслојна супер изолација (D)

\subsubsection{3 Криобиолошки контејнери (Деварови садови)}

a) Bioarchive Роботски систем - Деваров сад + замрзнувач со контролирана стапка на ладење за примероци крв од папочна врвца. 


\section{Систем BioArchive}

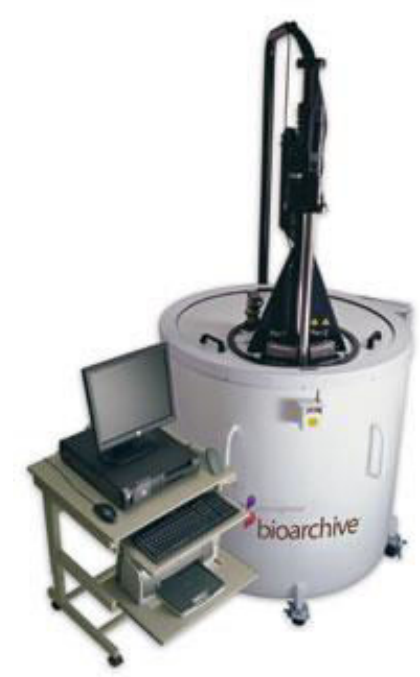

Слика 41: BioArchive Роботски систем за складирање на матични клетки

Системот BioArchive ${ }^{\mathrm{TM}}$ (Слика 41) е компјутерски контролиран систем за криопрезервација и складирање на течен азот кој овозможува замрзнување и управување со 3623 примероци крв од папочна врвца од по $25 \mathrm{ml}$.

Прецизна и автоматска грижа за примероците

BioArchive интегрира контролирано замрзнување, роботско складирање и вадење на примероците во еден единствен автоматски систем. Софтверот за системот за управување со примероци помага за усогласеност со GMP и добра работна пракса во банки на ткива.

Со интегрирање и автоматизирање на функциите, BioArchive обезбедува прецизно ракување со примероците и го намалува ризикот од грешка на операторот и изложеноста на течен азот. Интеграцијата исто така помага да се одржи интегритетот на примерокот бидејќи мануелниот трансфер од замрзнувачот со контролирана стапка на ладење (Controlled-Rate Freezer - CRF) до складирањето во течен азот е елиминиран, што ја намалува и фреквенцијата и последиците од привремената изложеност на примероците на собна температура (TWE).

Стандардизираните кеси за замрзнување дозволуваат повторливо замрзнување, плус роботско складирање и вадење на примероците. Системот BioArchive има два интегрирани модули на замрзнувачот со контролирана стапка на ладење за замрзнување и складирање на примероците.

Составни делови на системот: 


\section{Деваров сад со течен азот}

Деваров сад со течен азот (Слика 42) претставува вакуумски изолиран резервоар од не’рѓосувачки челик кој собира 520 литри течен азот. Кога е наполнет, Деваровиот сад за складирање ги одржува сите примероци на температура од $-196^{\circ} \mathrm{C}$. На држачите за складирање може да сместат 3623 примероци од по $25 \mathrm{ml}$ во концентричен распоред заради пристап на роботската рака и собирање со помош на перископ. До внатрешноста на Деваровиот сад за складирање може да се пристапи преку два отвори кои се покриени кога не се употребува.

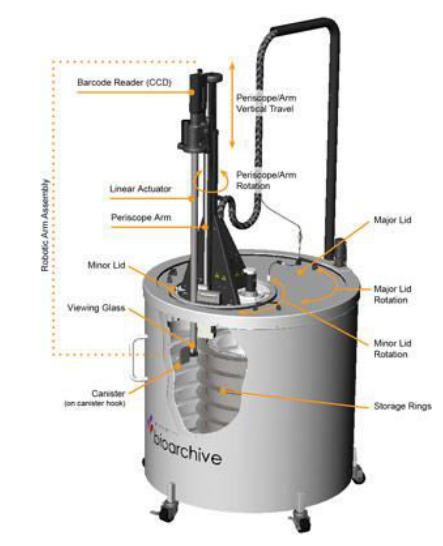

Слика 42. Деваров резервоар

Замрзнувач со контролирана стапка на ладење

Двата интегрирани модули на Замрзнувачот со контролирана стапка на ладење, кои може да се искористат истовремено, се обезбедени со Системот BioArchive. Модулите на Замрзнувачот со контролирана стапка на ладење имаат врати споени со шарки и доволно изолација за да спречат замрзнувачки шок. Вентилаторот сместен на задниот дел на вратите на замрзнувачот го одредува степенот на замрзнување на примерокот со изнесување на азотна пареа преку внатрешноста на комората за замрзнување (Слика 43). Замрзнувањето на примероците следи по претходно дефиниран профил во три чекори до $-50^{\circ} \mathrm{C}$ во кое време примерокот се пренесува до адреса во течниот азот. Овој процес овозможува одлична отпорност на клетките после замрзнувањето. 


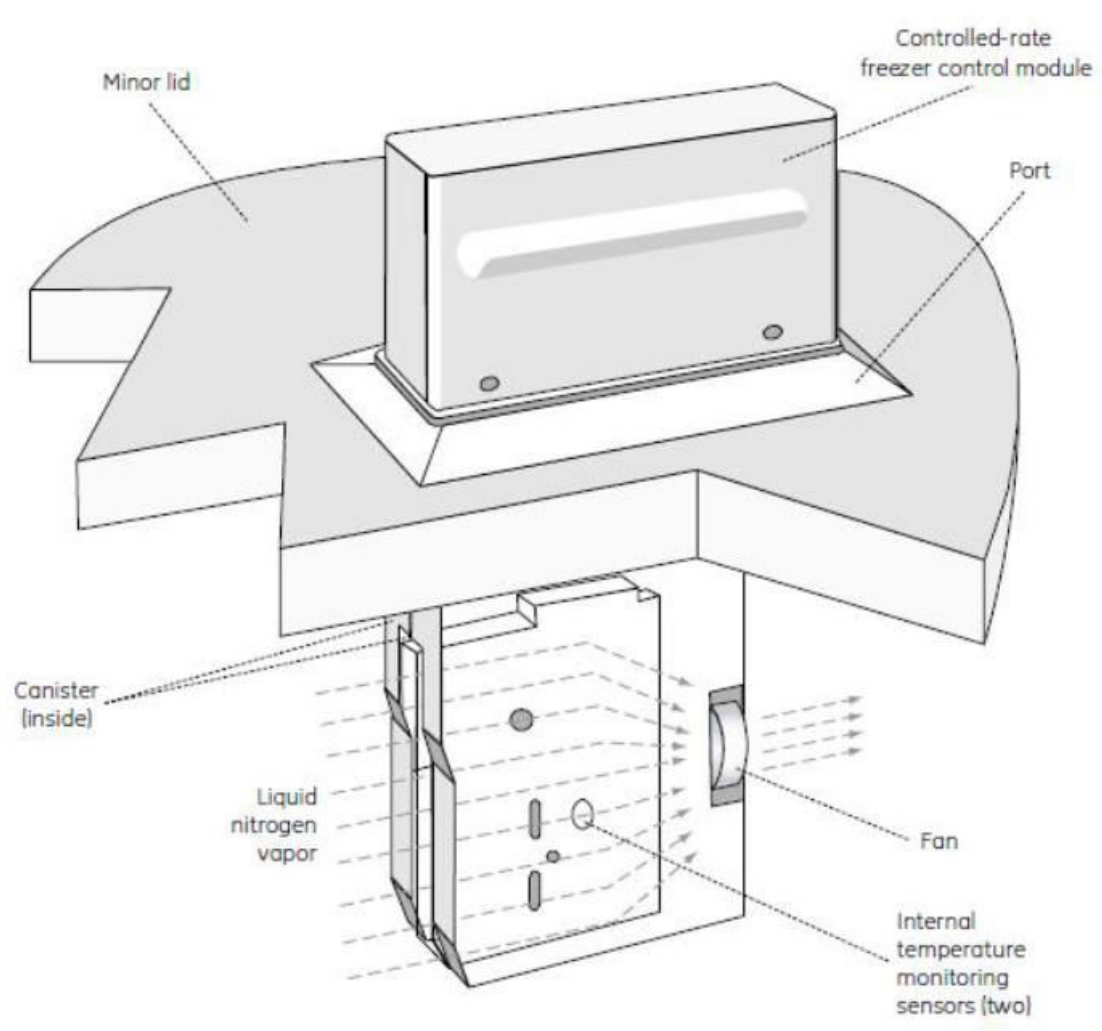

Слика 43: Модули на замрзнувач со контролирана стапка на ладење

\section{Роботска рака}

Роботската рака е систем кој го потврдува идентитетот на примерокот, потоа го складира и го вади примерокот од посебни адреси на складирање во Деваровиот сад. Роботската рака има скенер за CCD баркод сместен на врвот од раката на перископот која е оптички поврзана со стаклото за гледање на долниот дел на раката на перископот. Скенерот за баркод ја чита ознаката на баркодот на канистерот во моментот кога рачката на канистерот на роботската рака го зафаќа канистерот со примероци (Слика 44).

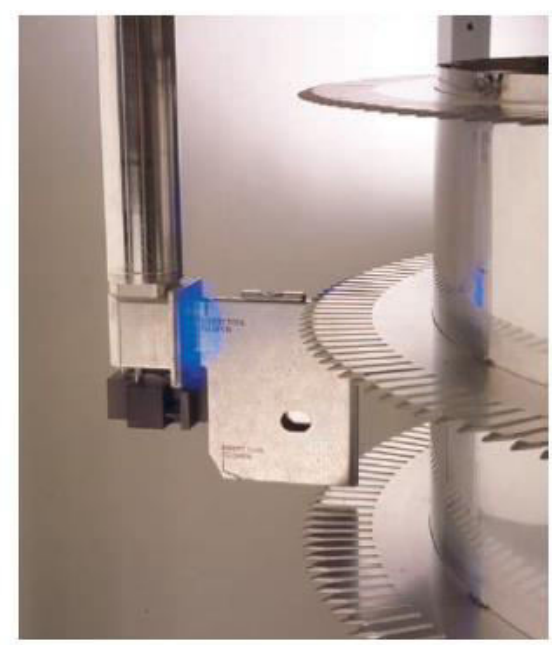

Слика 44: Роботска рака со канистер со примероци 


\section{Кертриџ за вадење}

Кертриџот за вадење (Слика 45) се користи за вадење на замрзнатите примероци. Сличен е на замрзнувачот со контролирана стапка на ладење освен што ги нема двете врати и вентилаторот. На нивно место има рамка која ја држи обвивката од пена на канистерот. Обвивката на канистерот го штити примерокот од загревање кога се отстранува од складиштето во BioArchive.

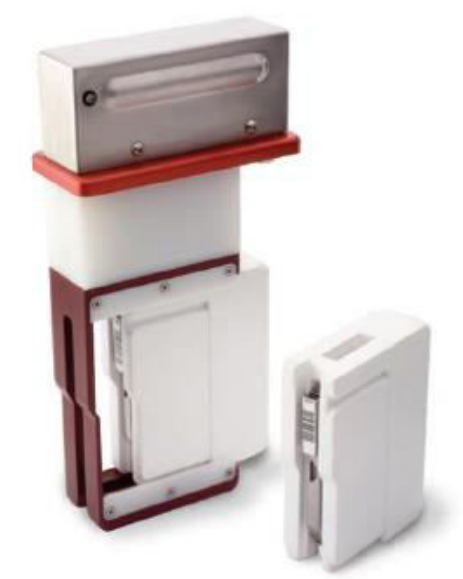

Слика 45: Кертриц за вадење со канистер за примероци во обвивка

\section{Работна станица}

Работната станица BioArchive вклучува компјутер, монитор, скенер за баркод, печатач и дупликатор на етикети. Софтверот за системот за управување со примероци им дозволува на корисниците со административни привилегии да креираат, менуваат и зачувуваат профили за замрзнување. Скенерот за баркод се користи за да се внесе идентификацискиот број на примерокот при складирањето и вадењето на примероците. Дупликаторот на етикети ги печати етикетите со баркодови со истиот број како и примерокот за етикетирање на кесата за замрзнување и канистерот за складирање.

\section{Систем за контрола на течен азот}

Системот за контрола на течен азот, врши постојано следење и открива кога нивото на течен азот е над или под претходно поставените вредности.

\section{Систем за микропроцесорска контрола}

Микропроцесорот го контролира движењето на роботската рака и отворањето и затворањето на вратите на замрнзувачот со контролирана стапка на ладење. Системот за 
контрола исто така, систематски ги дава специфичните адреси на кои секој канистер кој содржи примерок треба да се складира и ја одржува локацијата на секој специфичен примерок во базата на податоци.

Откако замрзнувањето ќе се комплетира, во базата на податоците се меморира идентификацискиот број на примерокот, времето и датумот кога примерокот е замрзнат, како и податоците за температурата и времето за време на замрзнувањето на примерокот. BioArchive поседува непрекинато напојување кое овозможува комплетирање на поставувањето или вадењето на примерокот во случај на прекин на електрична енергија.

Директива за медицински уред според која се рангираат контејнерите Директива ЕС 93/42/ЕЕ3 за медицински уреди (Законодавна уредба 95/98).

Контролен панел ТЕС 3000

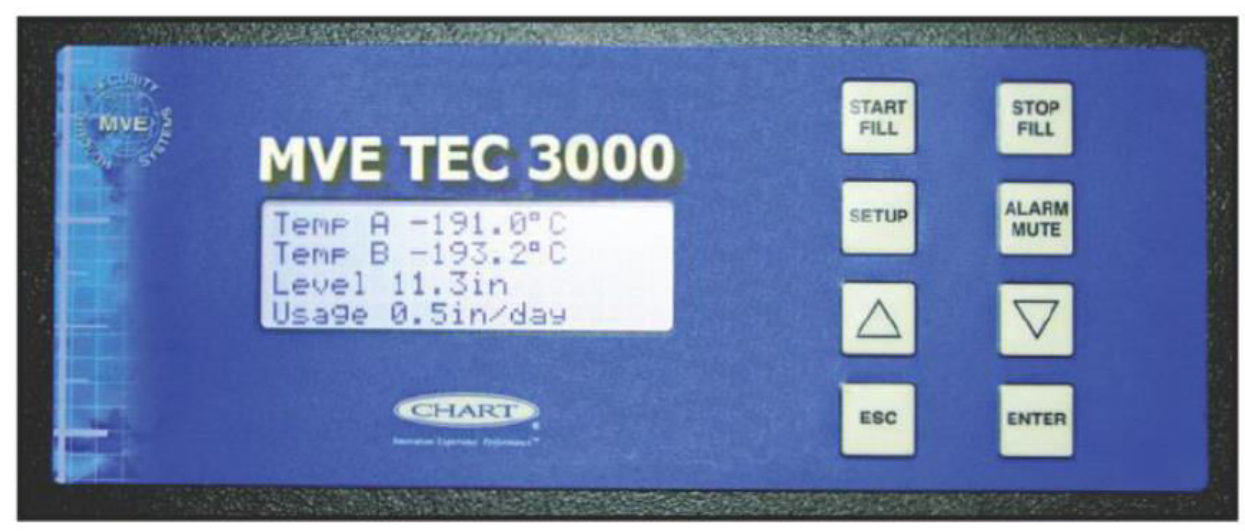

Слика 46: Контролен панел за ВіоArchive системот

TEC 3000 е напреден систем кој со своите карактеристики му овозможува на контролерот да ја следи и контролира средината во замрзнувачот со високо ниво на прецизност.

\section{PC485/ASCII/MOBDUS}

- Меморија: Чува запишана информација за време и датум на последните 30.000 контролни настани.

Криогените системи за конзервација на биолошко продукти, MVE, се дизајнирани, произведени и тестирани во согласност со систем за контролата на квалитетот и напредна безбедност.

Сите производи за пазарот на криобиологија, се дизајнирани, произведени и дистрибуирани со следење на квалитетен систем одобрен во согласност со ISO 9000. 


\section{б) Деварови садови MVE Chart - Транспортери со парна фаза за транспорт на примероци}

Серијата транспортери на пареа, е дизајнирана за безбеден транспорт на биолошки примероци на криогени температури $\left(-150^{\circ} \mathrm{C}\right)$.

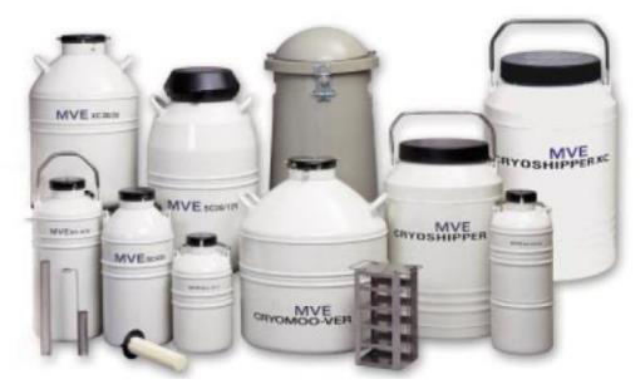

Слика 47: Деварови садови за транспорт на клетки

Изработени се од издржлив, лесен алуминиум, со вграден хидрофобичен апсорбент, кој содржи течен азот за транспорт „без истурање“.

Апсорбентот исто така одбива влага и влажност, обезбедувајќи максимално време на одржување. Тоа ја елиминира потребата за сушење на единиците помеѓу употребите. Заштитно пакување за транспорт, достапен за сите модели, кој го штити контејнерот од навалување, и помага при сигурноста на транспортот.

Овие контејнери може да се искористат за транспорт на примероци, со класификација „неопасни“ низ целиот свет, намалувајќи ги трошоците и овозможувајќи безбедност на примероците.

Во сите модели вклучени се држачи и канистери за складирање на биолошки материјали (цевки, ампули, кеси со крв). 


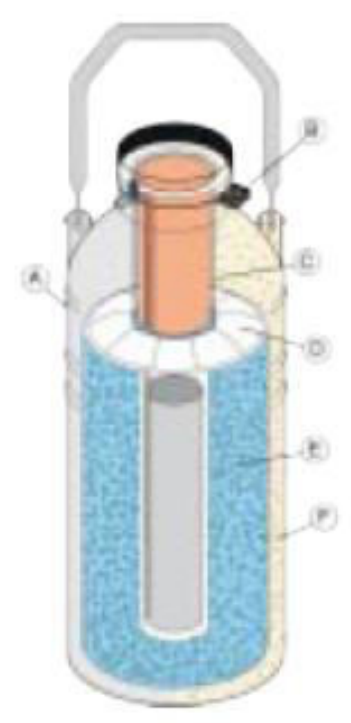

Слика 48: Шема на MVЕ крио транспортер
А. Дизајнот од лесен алуминиум ги намалува трошоците за транспорт
В. Сите модели доаѓаат со механизам за заклучување за цели на транспорт
C. Цевка кај грлото - цврстата цевка кај грлото ја намалува загубата на течен азот
D. Напредниот систем за хемиско задржување на вакуум овозможува одлични перформанси на вакуумот

Е. Одличен хидрофобичен апсорбент - лесен за деконтаминација - одбива влага и влажност при одржување на средина во комората од $-150^{\circ} \mathrm{C}$

F. Изолација - Напредниот систем за изолација од брендот MVE овозможува максимални термални перформанси

\subsubsection{4 Садови под притисок}

Садот под притисок има изолирана вакуумска заштитна обвивка од не’рѓосувачки челик, идеален е за транспорт, складирање, испорака на криогени течности под низок притисок, и обично се користи за течен азот.

Сите уреди се во согласност со Европските регулативи TPED (Директива за транспортна опрема под притисок). 
Деварови садови BioArchive - Wessington Cryogenics PV4Oо согласно Директивата за транспортна опрема под притисок

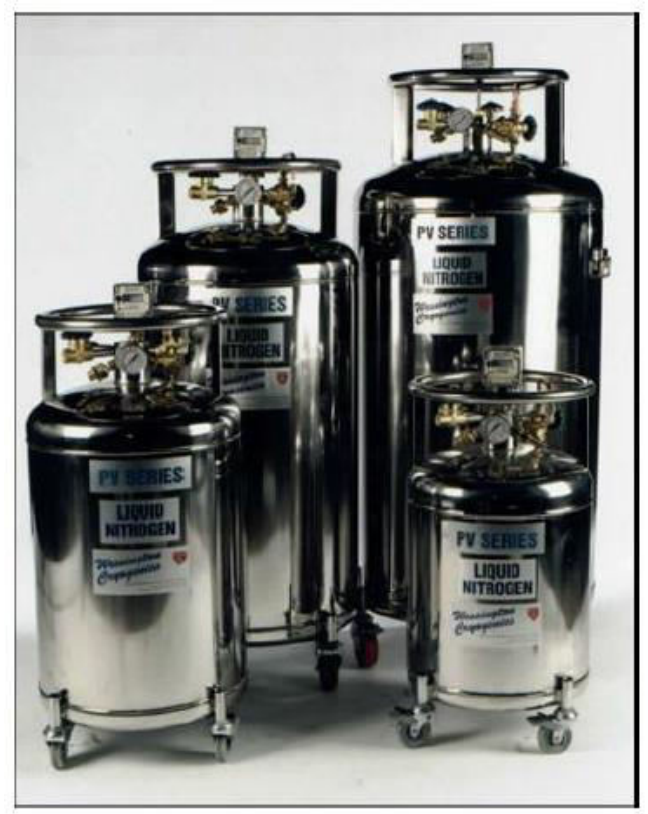

Слика 49: Сад за складирање на азот

Серијата PV на садови под притисок за складирање на течен азот и аргон е соодветна за примена во индустриско, медицинско, истражувачко и криобиолошко поле. Секој сад е дизајниран автоматски да го одржи притисокот на претходно поставеното ниво користејќи регулатор за создавање на притисок.

\subsubsection{5 Систем за надзор}

Општ опис на системот за надзор (кој се користи за биобанка и лабораторија)

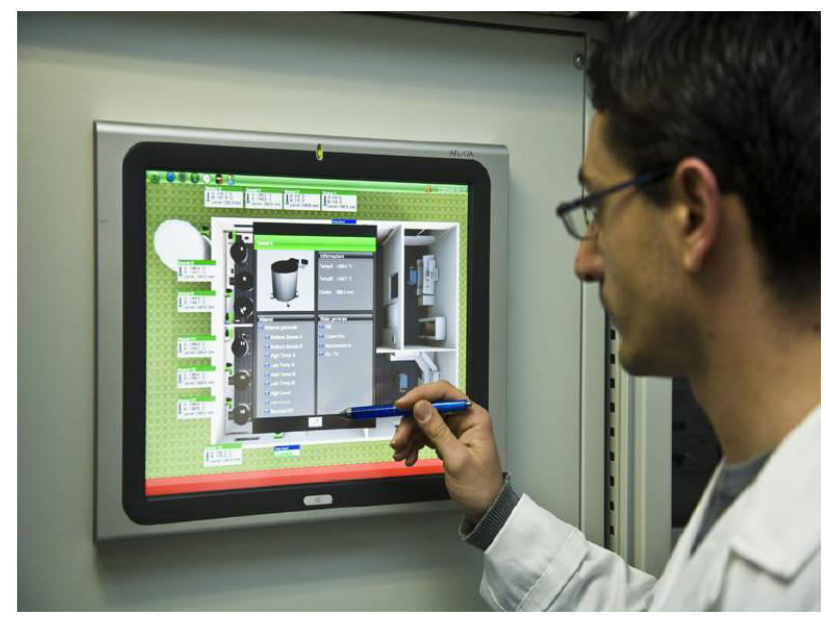

Слика 5о: Визуелено следење и контрола на биобанката и лабараторијата 
Системот за надзор и автоматизација е SCADA (Supervisory Control and Data Acquisition - Систем за супервизорно управување и аквизиција на податоци), т.е. може да следи и контролира инсталации во медицински и индустриски полиња.

Системот е модуларен и е составен од 3 дела:

-Програмабилен Логички Контролер (PLC): кој извршува операции на автоматизација и контрола низ целиот систем. Опремен е со приклучок RS422 или приклучок LAN-Ethernet co протокол TCP/IP за конекции со индустриски компјутер, повеќе комуникациски приклучоци RS485/RS422 за конекција со споредни далечински единици (RTU); -Деличински единици (RTU - Remote Telemetry and control Unit): модули поврзани со влезни / излезни уреди преку магистрала RS485. Далечинските единици може да бидат дигитални (S100) да читаат сигнали како сензорите за притисок, термистор сензори, да ограничат приклучоци итн. или аналогни да читаат вредности како на пример температура, притисок, нивоа, процент на кислород итн.;

-Индустриски компјутер (Industrial PC - IPC), поврзан од едната страна со Програмабилниот Логички Контролер преку приклучокот RS422 или приклучокот LAN-Ethernet, а од другата страна со интранет / интернет. Индустрискиот компјутер, користејќи го системскиот софтвер, управува со база на податоци (DBMS) и ја обезбедува функционалноста на веб серверот. 


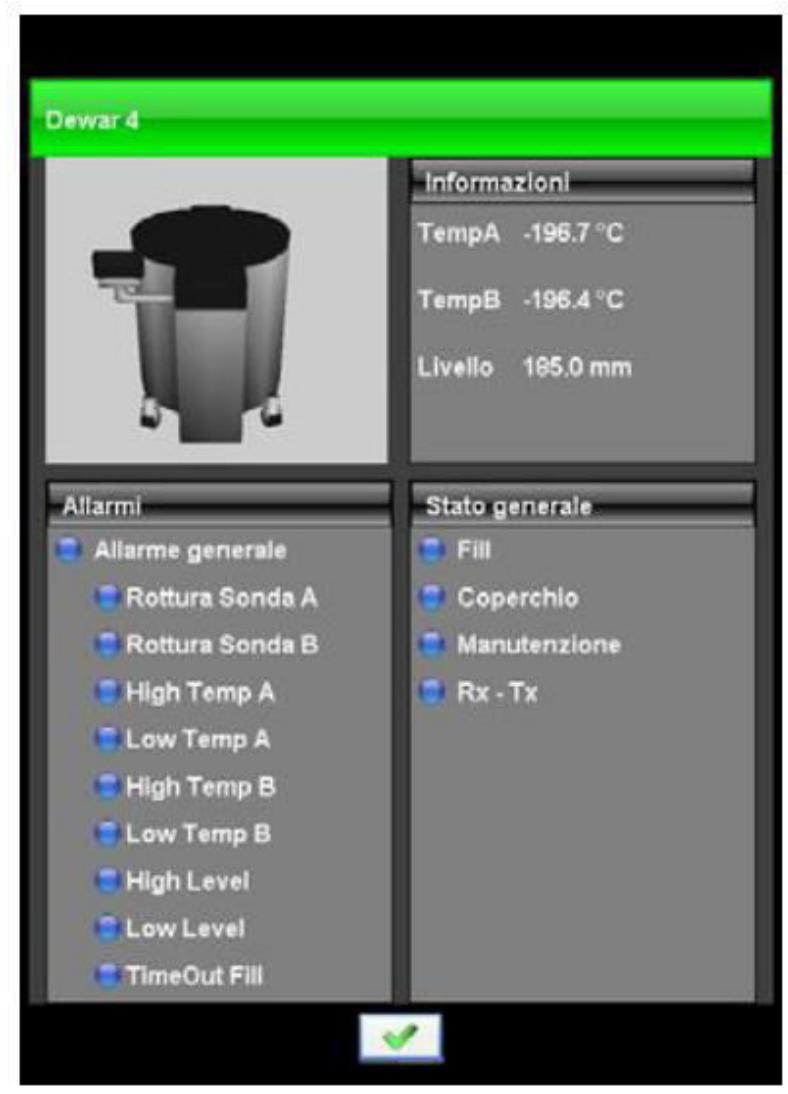

Слика 51: Детален приказ на Деваров сад

Софтверот за испраќање, во случај на аларм, може да испрати точни информации до операторите и до квалификуваните техничари.

Софтверот за пристап го контролира пристапот на операторот до критичните простори на погонот.

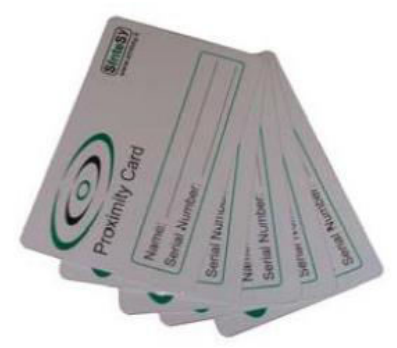

Слика 52: Безбедносни бецови за движење низ биобанката

Беџовите се читаат од радиофреквентни транспондери. Транспондерите S182 може да бидат вградени во 503 кутии од најпопуларните брендови.

Системот за антикражба автоматски се активира кога не е присутен ниту еден оператор во даден чувствителен простор и автоматски се деактивира кога операторот се регистрира со помош на беџот. 

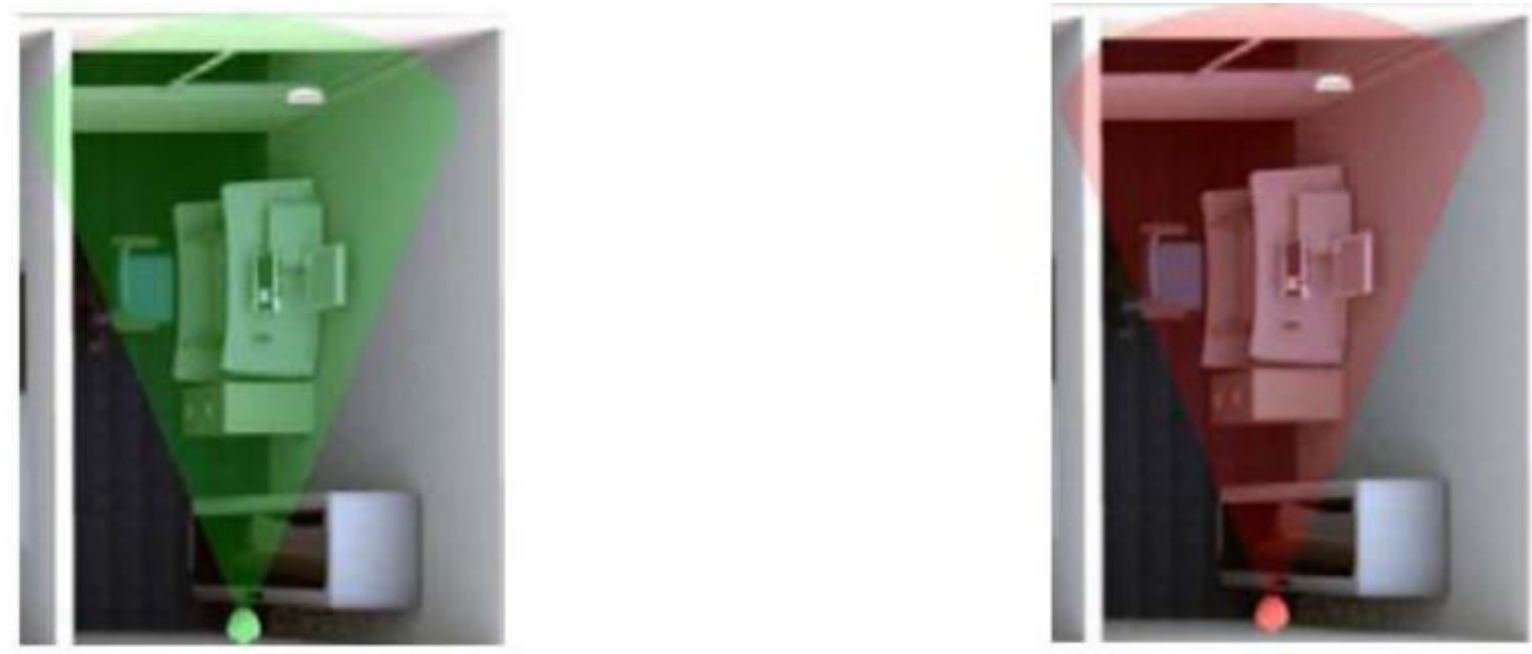

Слика 53: Графички приказ на аларм исклучен и вклучен

Модулот eagle.graph овозможува прикажување, печатење и експортирање на графикони, каде што оската х го претставува времето, а оската у ги претставува аналогните вредности. И времето и визуелизираните вредности се избираат преку соодветни компоненти внатре во апликацијата. Со користење на eagle.graph лесно е да се прикажат вредности складирани во базата на податоци, како на пример, температура, ниво, притисок, итн.

Модулот сrуо овозможува работа, на целосно автоматски начин, во зоната на складирање која користи течен азот (биобанка).

Складирање на податоци

Системот постојано ги складира податоците откриени во текот на неговото работење. Поточно, го следи секој настан, предупредување и аларм. Потоа, ги складира податоците за температура и нивоа на сите Деварови садови со минимален интервал од една минута.

Складираните податоци се обновуваат секои 12 месеци, така што корисникот се советува да изврши периодична дополнителна операција.

Складираните податоци можат автоматски да се зачуваат во далечна папка, дефинирана од крајниот корисник (на главен сервер или на компјутер).

По избор, може да се побара индустриски компјутер со систем RAID со двоен хард диск за да се зголеми сигурноста на податоците и можноста за реконструкција на податоците во случај на физичка оштета на еден хард диск. Во овој случај може да се гарантира период на складирање од 5 години.

Автоматизацијата на биобанката (контрола на Деварови садови, контрола на вентилација, контрола на ладење, контрола на пристап, итн.) целосно се управува со помош 
на интерактивен S300.smartPLC, кој има ЛЦД дисплеј во боја од $320 x 240$ пиксели со екран на допир, за да се конфигурира погонот.

Главна цел на автоматскиот систем е управување со автоматското полнење на криоконтејнерите и безбедноста на операторите во биобанката.

S30o.smartPLC, преку комуникации преку линијата RS485 кон RTU на системот, може да управува со:

-до 64 дигитални влезови (флуксометар, сонди за притисок, магнетни прекинувачи, сензори на движење, термални сензори, копчиња, итн.);

-до 64 дигитални излези (соленоидни вентили, сирени, светла, релеи, активатори, итн.);

-до 16 аналогни влезови о-20mA и/или 4-20mA (конвертори на притисок, конвертори на ниво, $\mathrm{O}_{2} / \mathrm{CO}_{2}$ сензори, ... , конвертори на температура, итн.);

-до 16 аналогни излези о-2оmA и/или 4/20mA (контролер на брзината на моторот за вентилација, отворач на пропорционалниот вентил, итн.);

-до 32 Деварови садови од типот S170 и/или ТЕС30оO;

-телефонски бирач кој испраќа алармни сигнали, преку гласовни пораки или СМС, до 8 различни телефонски броја со различни комбинации;

-до 4 главни цевководи со течен азот,со поврзани 4 влезни соленоидни вентили, 4 излезни соленоидни вентили, 4 сонди за температура.

S30o.smartPLC е поврзан со индустриски компјутер, кој, користејќи го софтверот на моторот, управува со меморирање на секоја вредност и секој настан на биобанката. Затоа е можно, на пример, да се архивираат во база на податоци температурите на Деваровите садови или нивоата на азот.

S30o.smartPLC е опремен со екран на допир и меки копчиња кои овозможуваат практична употреба. Удобната и функционалната транспарентна кутија, со клуч, овозможува пристап само до овластениот персонал.

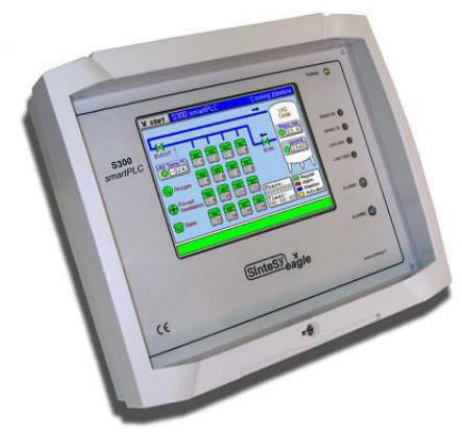

Слика 54: PLC Modul S3oo 
Графичката мапа ги потенцира физичките карактеристики на погонот и вредностите кои ја сочинуваат (на пример, $\% \mathrm{O}_{2}$, температура на цевководот, количина течен азот во резервоарот, притисок во резервоарот, ...).

Обично се вградува електричен орман со следниве димензии: -Ширина $=600 \mathrm{~mm} \times$ Должина $=400$ х висина $=1800 \mathrm{~mm}$ светло сива RAL 7032

Анализата на податоци со помош на графикони овозможува, на пример, директно да се анализира потрошувачката на течен азот. Оваа анализа исто така е олеснета од можноста да се следат различни вредности на истата временска оска, па така се споредуваат различни начини на работа.

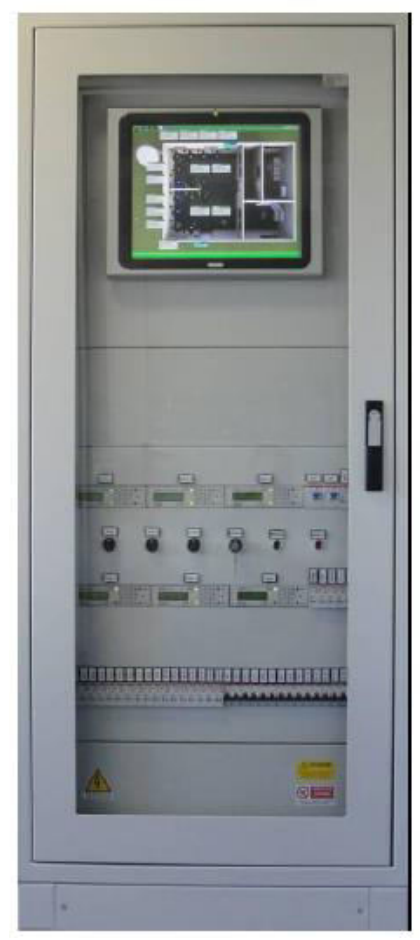

Слика 55: Електричен орман за контрола на параметрите во биобанката

Постојат постапки кои овозможуваат да се спореди потрошувачката во литри на надворешниот резервоар со фазите на полнење на поединечните контејнери.

Табела 5: Производите опишани во овој документ се во согласност со следниве стандарди

\begin{tabular}{|l|l|l|}
\hline Број & Наслов & Издание \\
\hline EN 60601-1 & $\begin{array}{l}\text { Медицинска електрична опрема - Дел 1: Општи барања за } \\
\text { безбедност }\end{array}$ & $2006^{28}$ \\
\hline EN 60601-1-1 & $\begin{array}{l}\text { Медицинска електрична опрема - Дел 1-1: Општи барања за } \\
\text { безбедност - Колатерален стандард: Барања за безбедност за } \\
\text { медицински електрични системи }\end{array}$ & $2001^{29}$ \\
\hline
\end{tabular}

$28 \quad$ EN 60601-1:2006

$29 \quad$ EN 60601-1-1:2001 


\begin{tabular}{|c|c|c|}
\hline EN 60601-1-2 & $\begin{array}{l}\text { Медицинска електрична опрема. Општи барања за безбедност. } \\
\text { Колатерален стандард. Електромагнетна компатибилност. } \\
\text { Барања и испитувања. }\end{array}$ & $2007^{30}$ \\
\hline $\begin{array}{l}\text { EN 60601-1-4 } \\
+ \text { A1 (1999) }\end{array}$ & $\begin{array}{l}\text { Медицинска електрична опрема - Дел 1: Општи барања за } \\
\text { безбедност 4. Колатерален стандард: Електрични медицински } \\
\text { системи што може да се програмираат }\end{array}$ & $1996^{31}$ \\
\hline EN 60601-1-6 & $\begin{array}{l}\text { Медицинска електрична опрема } \\
\text { Дел 1: Општи барања за безбедност - Колатерален стандард: } \\
\text { Употребливост }\end{array}$ & $2007^{32}$ \\
\hline EN 60601-1-8 & $\begin{array}{l}\text { Медицинска електрична опрема - Дел 1: Општи барања за } \\
\text { основна безбедност и суштински перформанси - Колатерален } \\
\text { стандард: Општи барања, испитувања и упатство за алармни } \\
\text { системи во медицинската електрична опрема и медицинските } \\
\text { електрични системи }\end{array}$ & $2007^{33}$ \\
\hline EN 60304 & Софтвер за медицински уреди & $1982^{34}$ \\
\hline EN 7396-1 & $\begin{array}{l}\text { Медицински цевководни системи - Дел 1: Цевководни системи } \\
\text { за компримирани медицински гасови и вакуум }\end{array}$ & $2007^{35}$ \\
\hline EN 61000-6-2 & $\begin{array}{l}\text { Електромагнетна компатибилност (EMC). Генерички стандарди. } \\
\text { Отпорност кај индустриските средини. }\end{array}$ & $2001^{36}$ \\
\hline $\begin{array}{l}\text { EN } 55024 \\
+\mathrm{A} 1(2001) \\
+\mathrm{A} 2(2003)\end{array}$ & $\begin{array}{l}\text { Опрема за информациска технологија. Карактеристики на } \\
\text { имуност. Ограничувања и методи за мерење. }\end{array}$ & 199837 \\
\hline EN $301489-7$ & $\begin{array}{l}\text { Електромагнетна компатибилност и радио спектар; Стандард за } \\
\text { електромагнетна компатибилност за радио опрема и услуги; Дел } \\
\text { 7: Специфични услови за мобилно и преносно радио и помошна } \\
\text { опрема за дигитални целуларни радио телекомуникациски } \\
\text { системи (GSM и DCS) }\end{array}$ & $2005^{38}$ \\
\hline $\begin{array}{l}\text { EN } 301511 \\
\text { V9.0.2 }\end{array}$ & $\begin{array}{l}\text { Глобален систем за мобилни комуникации (GSM); Усогласен } \\
\text { стандард за мобилни станици во опсезите GSM 90о и GSM 1800, } \\
\text { што ги опфаќа суштествените барања според член } 3.2 \text { од } \\
\text { Директивата R\&TTE (1999/5/E3)-V9.o.2 }\end{array}$ & $2003^{39}$ \\
\hline EN 50385 & $\begin{array}{l}\text { Производствен стандард што го покажува придржувањето на } \\
\text { базните радиостаници и фиксните терминални станици за } \\
\text { безжични телекомуникациски системи со основните } \\
\text { ограничувања или препорачаните нивоа што се однесуваат на } \\
\text { човечката изложеност на радиофреквенциски електромагнетни } \\
\text { полиња (110 MHz - 40 GHz) - Општа јавност }\end{array}$ & 200240 \\
\hline ISO 14971 & $\begin{array}{l}\text { Медицински помагала - Примена на управување со ризик на } \\
\text { медицински помагала }\end{array}$ & $2009^{41}$ \\
\hline ISO 9001 & Систем за менаџмент со квалитет - Барања за регулаторни цели & $2008^{42}$ \\
\hline IS & $\mathrm{C}$ & 43 \\
\hline
\end{tabular}

$30 \quad$ EN 60601-1-2:2007

$31 \quad$ IEC 60601-1-4:1996

$32 \quad$ EN 60601-1-6:2007

33 EN 60601-1-8:2007

34 IEC 60304:1982(E)

$35 \quad$ EN ISO 7396-1:2007

$36 \quad$ EN 61000-6-2:2001

$37 \quad$ EN 55024: 1998+A1: 2001+A2: 2003

$38 \quad$ EN 301 489-7:2005

$39 \quad$ EN 301 511 V9.0.2:2003

$40 \quad$ EN 50385:2002

$41 \quad$ ISO 14971:2009

42 ISO 9001:2008

43 ISO 13485:2003 


\begin{tabular}{|l|l|l|}
\hline $\begin{array}{l}\text { Директива } \\
\text { 93/42/ЕЕ3 и } \\
\text { 2007/47/EЕ3 }\end{array}$ & Директива за медицински уреди & 2007 \\
\hline Директива & Што се однесува на машини и ја измени и дополни Директивата & 2007 \\
2006/42/EЕ3 & 95/16/Е3 & \\
\hline
\end{tabular}

\subsubsection{6 Систем за вентилација}

Со цел да се осигураат услови за безбедност за корисниците, потребни се најмалку два детектори на кислород, поврзани со систем за вентилација, со следниве карактеристики:

-Стандардна брзина: најмалку $10 \mathrm{vol} / \mathrm{h}$ секогаш вклучен;

-Голема брзина: најмалку $25 \mathrm{vol} / \mathrm{h}$ засилена вентилација;

- внес на воздух од биобанка користејќи алуминиумска решетка која е поставена на sидот надвор од зградата;

- аспирација на воздух од панел или од соседната просторија со помош на решетка со надпритисок која е поставена на горниот дел од вратата, со цел да се внесе соодветната количина на воздух за да се одржи локалниот во негативен притисок, во споредба со надворешниот воздух и воздухот во околните простории;

- исфрлање на воздухот надвор со помош на единица за аспирација, поставена и наместена, со соодветни затварачи во просторија која е соседна на локалната, за криопрезервација, со соодветна инсталација на ПВЦ цевки, со цел да се спроведе воздухот надвор од зградата.

Секој детектор има излезен сигнал од 4-20 mA и е поврзан со специфичен уред и програмиран со 2 прага на аларм, во комуникација со системот за вентилација.

Доколку се надмине првиот праг, системот за аларм почнува да sвони и се активира втората брзина на системот за вентилација.

Доколку се надмине вториот праг, системот за вентилација останува вклучен со активирана втора брзина и во исто време се активира постапката за аларм.

Мотор со излез за воздух: Модел 4/6-полен, директно споен со двојна брзина во три фази, 0,55 киловати / o,18 IP со цел да ги има двете функционални состојби.

\section{Канали за воздух}

Серија на материјали за испуштен воздух кои ќе се инсталираат со цел да се спроведе воздухот надвор од зградата, и сите се составени од следниве елементи:

-делови од ПВЦ цевка;

-спојка флексибилна во ПВЦ;

-конектор со мотор со капак;

-ПВЦ редуцирања; 
-конзоли за монтирање на издув на моторот;

-бели ПВЦ единици кои се поставуваат на решетката од аспираторот;

-прекривка за мотор од ПВЦ.

Локална решетка за криопрезервација при внес на воздух

Решетка од алуминиум за внес на воздух инсталирана на надворешниот sид, комплетирана со пригушувач на воздух, со можност за прилагодување.

Решетка за внес на воздух

Решетка со надпритисок за внесување на воздух направена од поцинкуван лим и алуминиум и опремена со мрежа против птици.

\subsubsection{7 Системи за следливост}

Со цел да се осигура целосна следливост на примероците, се користат специфични печатачи на бар код етикети, скенери и криогени етикети.
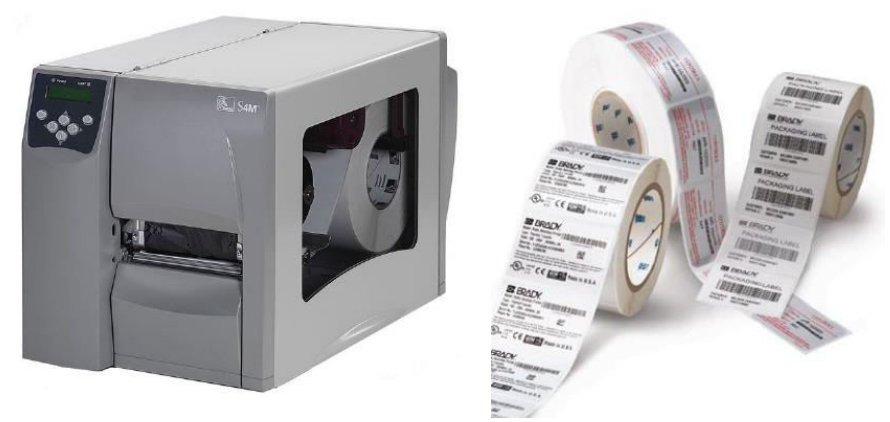

Слика 56: Систем за печатење на бар код етикети

Етикетите се направени да траат долго време (најмалку 30 години), да се лепат на секој примерок и да бидат отпорни на сите главни хемиски или механички дејства кога се во течен азот и кога се ракува со нив.

Исто така овие етикети може да се стават на веќе замрзнати шишиња/кеси за крв. На секоја етикета се печати, користејќи го уредот на сликите подолу, специфичен бар код, всушност некој вид на група броеви и тоа ја овозможува целосната следливост на секој примерок и во поглед на настани и во поглед на местоположба внатре во деваровиот сад. 


\subsubsection{8 Лични заштитни средства}

Употребата на опрема за лична заштита, е од особена важност за правилната употреба на алатите и опремата кои вклучуваат употреба на течен азот.

Заради ова, мора да се обезбеди:

- криогени заштитни ракавици, водоотпорни, направени за работа во криогена атмосфера (особено течен азот) при температури од $-160^{\circ} \mathrm{C}$ до $+148^{\circ} \mathrm{C}$, и за работа со алатки / ултра студени објекти (кутии, криогени замрзнати шишиња, кеси, итн.) повеќеслојна изолација за заштита на дланките и рацете, лесни и флексибилни, издржливи, хигиенски, со одлична изработка, со гаранција за удобна внатрешна температура;

- криогени престилки со изолациони слоеви, за заштита на многу површини од контакт со ултра студени материи и прскање, направени со прилагодливи ремени и штипки на вратот и струкот, кои лесно се вадат;

- ПВЦ криогени гамаши кои се носат над чевлите за работа;

- криогени штитници за очи од чист поликарбонат совршено транспарентни и некршливи, кои се состојат од штитник за лице и прилагодлив ремен за прицврстување.

\subsubsection{9 Детектори на кислород}

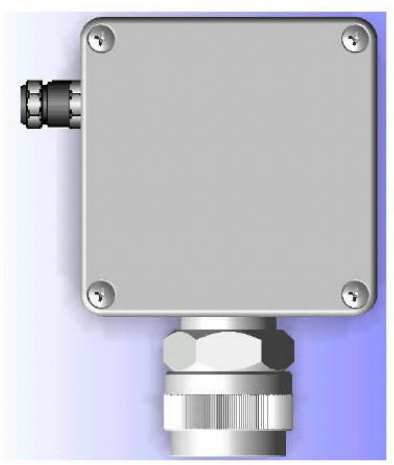

Слика 57: Графички приказ на детектор за кислород

Во просториите на биобанката ќе бидат инсталирани два сензори за детектирање на концентрации на кислород во средината.

Сензорите ќе се карактеризираат со излез од 4-20 mA и ќе се поврзат со модулот S110. Овој модул ќе биде програмиран со два аларми и ќе биде поврзан со системот за вентилација.

Читањата во реално време од страна на S110 ќе се праќаат до надзорниот компјутер кој ќе ги прикажува. 
Модулот S110 има LCD дисплеј на предниот дел кој ги прикажува вредностите. Во случај на надминување на првиот праг на аларм, ќе се издаде звучна и визуелна индикација на модулот S110.

Во случај на надминување на вториот праг на аларм, ќе се активира вентилацијата. Во исто време ќе се блокира влезот на соленоидниот вентил на цевководот за течен азот,за спречување на внесување на вишок азот во средината.

Надзорниот компјутер графички ги прикажува и снима алармите и ги запомнува настаните на хард диск.

Детекторите за гас се користат за детекција на недостаток или прекумерна количина на кислород.

Сензорите за кислород се користат во средини каде инертниот гас (пример азот) може да го намали процентот на кислород во воздухот, кој обично е околу 21\%. Процентот на кислород во воздухот помал од 19\% е опасен или смртоносен за луѓето.

Дури и во ситуации каде содржината на кислород надминува 23-24\% во воздухот треба да се следи бидејќи од една страна се зголемува запаливоста на материите, а од друга страна концентрацијата на кислород станува токсична за човечкото тело.

Обично мерењето на недостатокот на кислород се прави со електрохемиски сензори. Сензорите обично се лоцирани во истата кутија во која се наоѓ трансмитерот кој обезбедува електричен сигнал од 4-20 mА пропорционален на количината на кислород во воздухот. Сензорот на вратата на кутијата, обично се инсталира на sидот,со чувствителната страна надолу. Позиционирањето на сензорот мора да се направи според гасот кој е присутен во воздухот, што може да ја намали нормалната концентрација на кислород (околу 21\%).

Еве неколку примери:

1) течен азот

Сензорот се инсталира 70-80 cm над земја, затоа што течниот азот првично има тенденција да се таложи.

2) азот во фаза на гас

Сензорот се инсталира 100-120 cm над земја, затоа што густината на азотот е еднаква на онаа на воздухот.

Општо земено, детекторите на кислород кога се користат за да се открие присуството на други гасови кои предизвикуваат недостаток на кислород во средината мора да се инсталираат на околу 6о/100 cm над подот. 


\subsubsection{0 Машина за затворање на кеси за крв од папочна врвца}

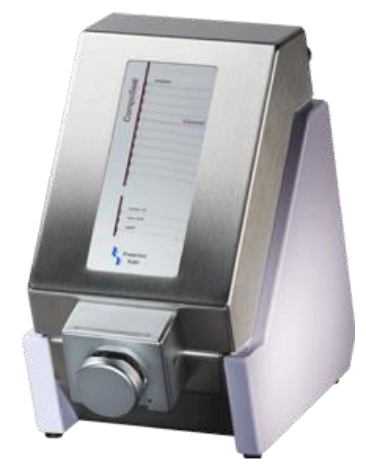

Слика 58: Машина за затворање на тубите со крв од папочна врвца

Composeal

Избор за нов стандард за контролирано, безбедно затворање на тубите. Висококвалитетни машини за затворање, сигурна работа, брзо и лесно ракување, контрола на процес која осигурува откривање на истекување.

Производната линија на Composeal нуди асортиман на машини за затворање кои ги исполнуваат специфичните барања на професионалците при затворање на медицински туби.

\subsubsection{1 Водена бања}

Julabo Спецификација за производот

F25-НЕ Разладен и загревачки циркулатор

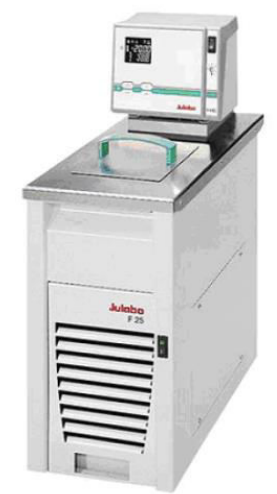

Слика 59: Водена бања за брзо одмрзнување на клетки 


\section{Опис}

Разладен и загревачки циркулатор за внатрешна и надворешна температурна примена. Разладните и загревачки циркулатори JULABO за ладење/загревање, се погодни за работни задачи на надворешна температура и за примена директно во бањата. Може да се избере модел од три различни серии со различни капацитети. Моќните системи со цирулаторни пумпи и големи капацитети за загревање и ладење, гарантираат кратко време за загревање и ладење. Неизбежното акумулирање на прав кое се јавува во системите за ладење, се решава со помош на отвор-решетка која лесно се отстранува и која овозможува лесно чистење. Во зависност од моделот, единиците се опремени со рачки или тркала за лесен транспорт. Сите модели имаат уред за одвод на предниот дел кој овозможува течноста лесно да се исцеди. Компактната монтажа на секоја единица овозможува да се заштеди простор во лабораторијата.

6.2.3.12 Вакумска пумпа ValuPump за отстранување DMSO

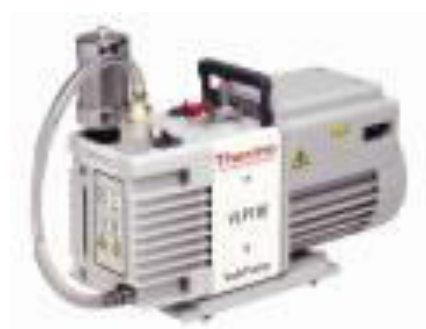

Слика 6о: Вакумска пумпа за отстранување на течност

6.2.3.13 Лабораториски уреди за проточна цитометрија

а) Автоматски луминометар

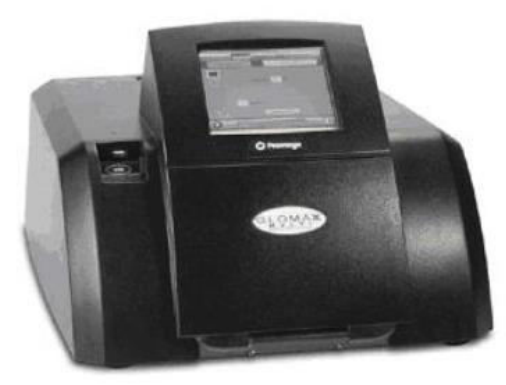

Слика 61: Луминометар 
Системот за детекција GloMax-Multi, составен од детектор на луминисценција GloMAx, има оригинален капацитет со повеќе режими, кој му овозможува да чита детекција на флуоресцентност и апсорпција кај плочи со 96 извори. Со едноставен интерфејс на екран на допир, функционира како независна работна станица. Нема потреба компјутер да го раководи инструментот. Научниците, може да прават експерименти според нивниот распоред, а потоа да ги префрлаат податоците во компјутер, во кое било време преку USB приклучок. Бидејќи нуди оптимизирани перформанси и претходно инсталирани протоколи, системот за детекција GloMax-Multi претставува идеална платформа за вклучување на испитувањата во сложени системи како што е случајот со новото сложено испитување за цитотоксичност MultiTox-Glo. Исто така достапен е и систем за инјектирање, за употреба со системот за испитување Dual-Luciferase Reporter (DLR $\left.{ }^{\mathrm{TM}}\right)$.

б) Beckman Coulter MoFlo XDP апарат за сортирање на клетки со голема брзина

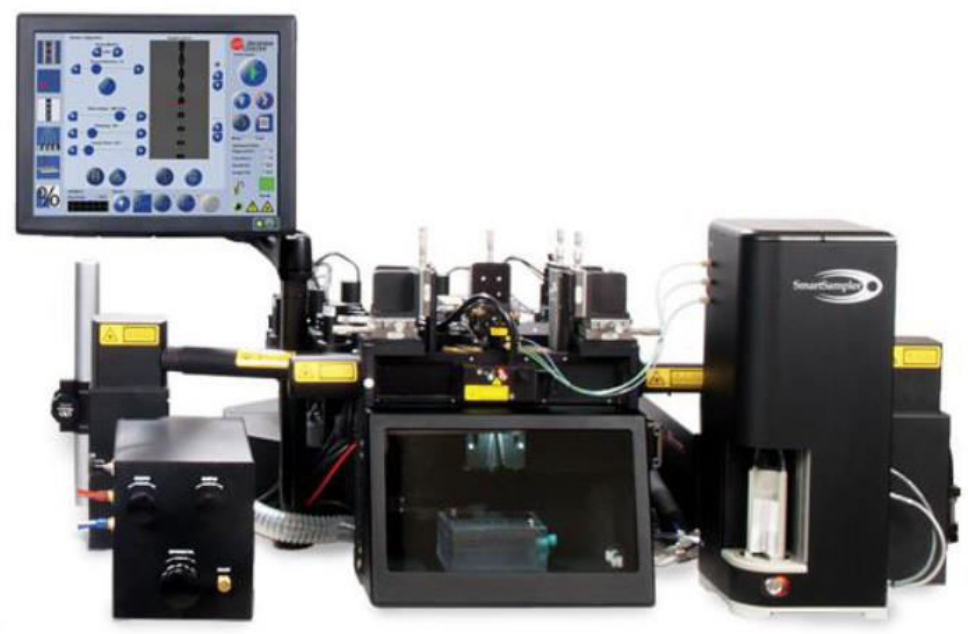

Слика 62: Апарат за сортирање на клетки

Стандардни компоненти

Проточен цитометар со ултра голема брзина со следниве спецификации и компоненти:

- Отворениот оптички и електронски дизајн дозволува лесно надградување на ласерите и каналите за флуоресцентност;

- Дигитална обработка на импулси со мртво време (време после секој настан во текот на кое системот не може да запише друг настан) кое изнесува нула;

- динамички опсег од 5 декади, со обработка на податоци со 32 бита;

- Активира секаков параметар, секаков ласер;

- Брзини на анализа до 200.0oo cell/sec; 
- Сортирањето се забрзува до и повеќе од 70.000 cell/sec;

- стапка на примерок од $100 \mathrm{MHz}$;

- Перформансите не зависат од бројот на ласери, порти за сортирање, компензација или насоки на сортирање.

\subsubsection{4 Лабораториски уреди за молекуларна генетика}

а) Автоматски ДНК екстрактор (AutoGenFlex STAR)

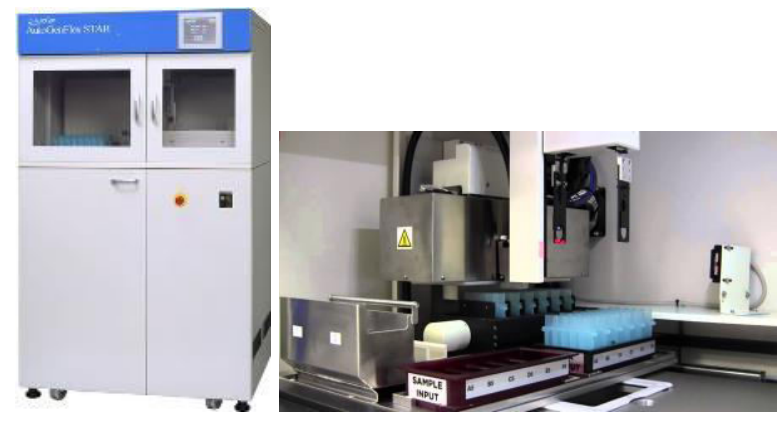

Слика 63: ДНК екстрактор со автоматизиран систем за екстракција

AutoGenFlex STAR е развиен како економично решение за целосно автоматизирана изолација на геномска ДНК и екстракција од големи волумени на цела крв. Комбинирајќи ги цврстите и сигурни инструменти на AutoGen и докажаната FlexiGene хемија на Qiagen, уредот STAR вади ДНК од 1,0 - 10,0 $\mathrm{ml}$ од цела крв. STAR е целосно автоматизиран и лесен за употреба, без потреба од рачна интервенција. Изолира до 40 примероци цела крв при една операција и произведува геномска ДНК со постојано висок квалитет и голема количина, подготвена за следна примена или долгорочно складирање во биолошки складишта. Исто така, достапно за STAR е следење на примероци и известување за идентификација на примероците со бар код. Системот исто така може да се користи за изолирање на ДНК од примероци на ткиво, клетки и примероци од плунка земени со помош на Oragene DNA.

б) Уред за полимерна верижна реакција во реално време (Real-time PCR)

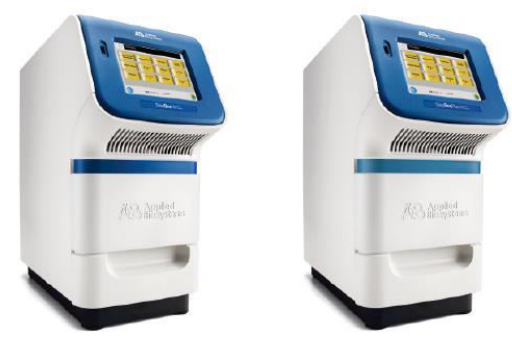

Слика 64: Систем за полимерна верижна реакција 
Примени на полимерна верижна реакција во реално време

И двата системи подржуваат многу примени на квантитативна полимерна верижна реакција во реално време, вклучувајќи анализа на генска експресија, користејќи релативна стандардна крива и компаративен СТ $(\Delta \Delta \mathrm{CT})$ за релативна квантификација и стандардна крива за апсолутна квантификација. Згора на тоа, системите овозможуваат квантитативно откривање после полимерната верижна реакција на нуклеински киселини за испитување со алелна дискриминација (SNP генотипизација) и испитување за присуство/отсуство (плус/минус) кое користи внатрешни позитивни контроли. Новите примени вклучуваат анализа на крива на точка на топење, како независна примена и зголемување на полимерна верижна реакција во реално време користејќи испитување со алелна дискриминација (SNP генотипизација) и испитување за присуство/отсуство (плус/минус) кое користи внатрешни позитивни контроли.

\section{Примени}

Системите StepOne, поддржуваат примена на полимеразна верижна реакција во реално време. Достапни се претходно дизајнирани испитувања или испитувања по нарачка за следниве примени:

-профил на генска експресија;

-SNP генотипизација;

-експресија на микроднк;

-анализа на транслокација;

-анализа на вирусно оптоварување;

-детекција на гени; 


\section{3. Анализа на проектот за мобилни, преградни, монтажно - демонтажни зидови}

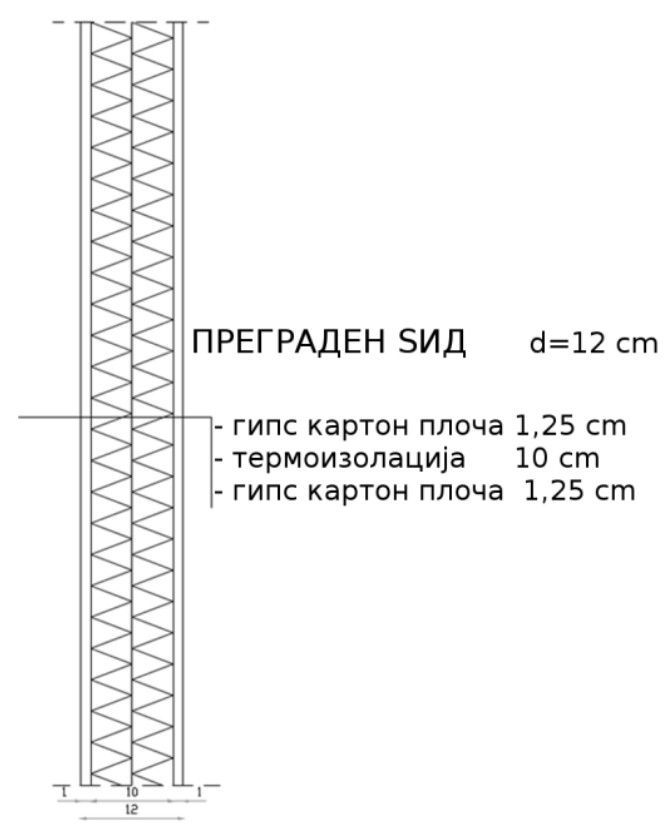

Слика 65: Детал од суво монтажен преграден зид

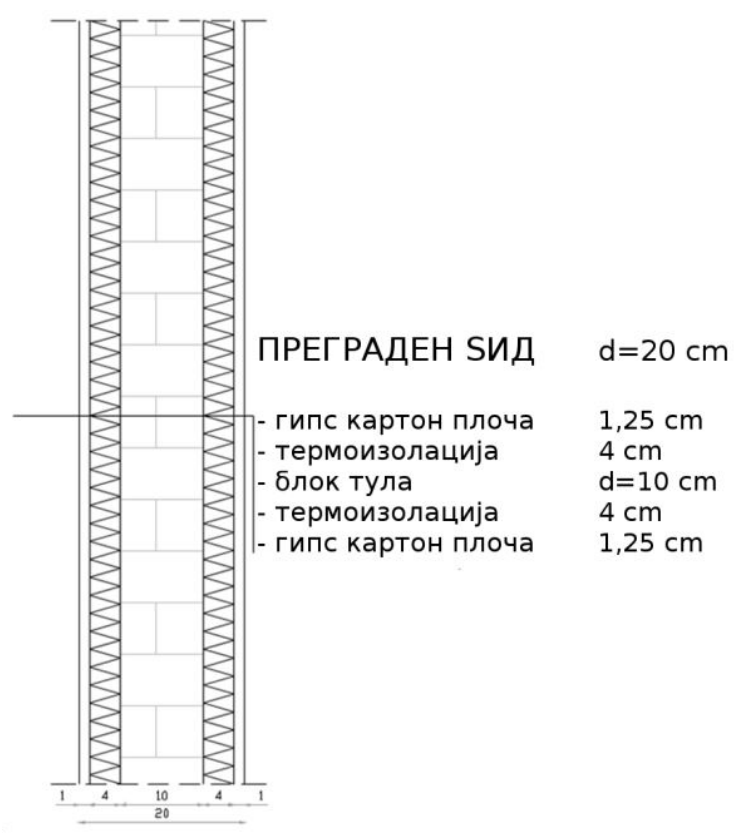

Слика 66: Детал од преграден зид во банката за матични клетки

6.4. Анализа на системско решавање на вештачкото осветлување и таваниците во просторот

Постојат голем број на студии кој укажуваат на влијанието на осветлувањето во работните простории врз комфортот, здравјето и продуктивноста на работникот. Со таа цел соодветно решение на осветлувањето е многу битно во лабораториите, ако се земе во предвид времето поминато од страна на истражувачите и тежината на работата што ја имаат. При анализа на вештачко осветлување на просторот, секогаш како примарен извор на светлина се зема природното осветлување, додека вештачкото се изведува како надополнување на природното44. Поставувањето на светлосните тела на плафонот се изведува во согласност со два примарни аспекти: насока на светлосниот зрак, која може да биде директна, индиректна или комбинирана директна/индиректна и локација на светлосното тело во однос на работната површина кое може да биде паралелно или нормално. Како најоптимално решение погодно за осветлување на лабораториите и кабинетите, е земено светлото да биде директно бидејќи индиректното предизвикува

\footnotetext{
44 LABORATORIES FOR THE 21 ST CENTURY: BEST PRACTICE GUIDE DOE/GO-102005, August 2006.
} 
чувство на досада и едноличност. Додека локацијата на светлосните тела е земена да биде паралелна со работната површина и поставена во линија со крајот од работната површина. На овој начин се избегнува рефлексијата и создавањето на сенки, кој пречат во работата. Истото важи и за банката за матични клетки.

За светлосни тела е земен моделот: CLEAN S-MP SUPREME LED MICROPYRAMIDAL OPTIC од 122 watt од австрискиот производител ZUMTOBEL. Како што тврди производителот ова осветлување ги задоволува стандардите на GMP Grade A, B и С за чисти соби, како и DIN EN ISO 14644-1 кој се постигнати со изработка на рамката од специјален анти - статички материјал кој не дозволува таложење на партикули на површината додека заштитното стакло е фиксирано со магнетни држачи кој овозможуваат лесно одржување. Меѓу другото овој модел овозможува инсталација и функционирање во простории со ламинарен проток (Слика 68) на воздух со позитивен или негативен притисок, како што е банката за матични клетки. 


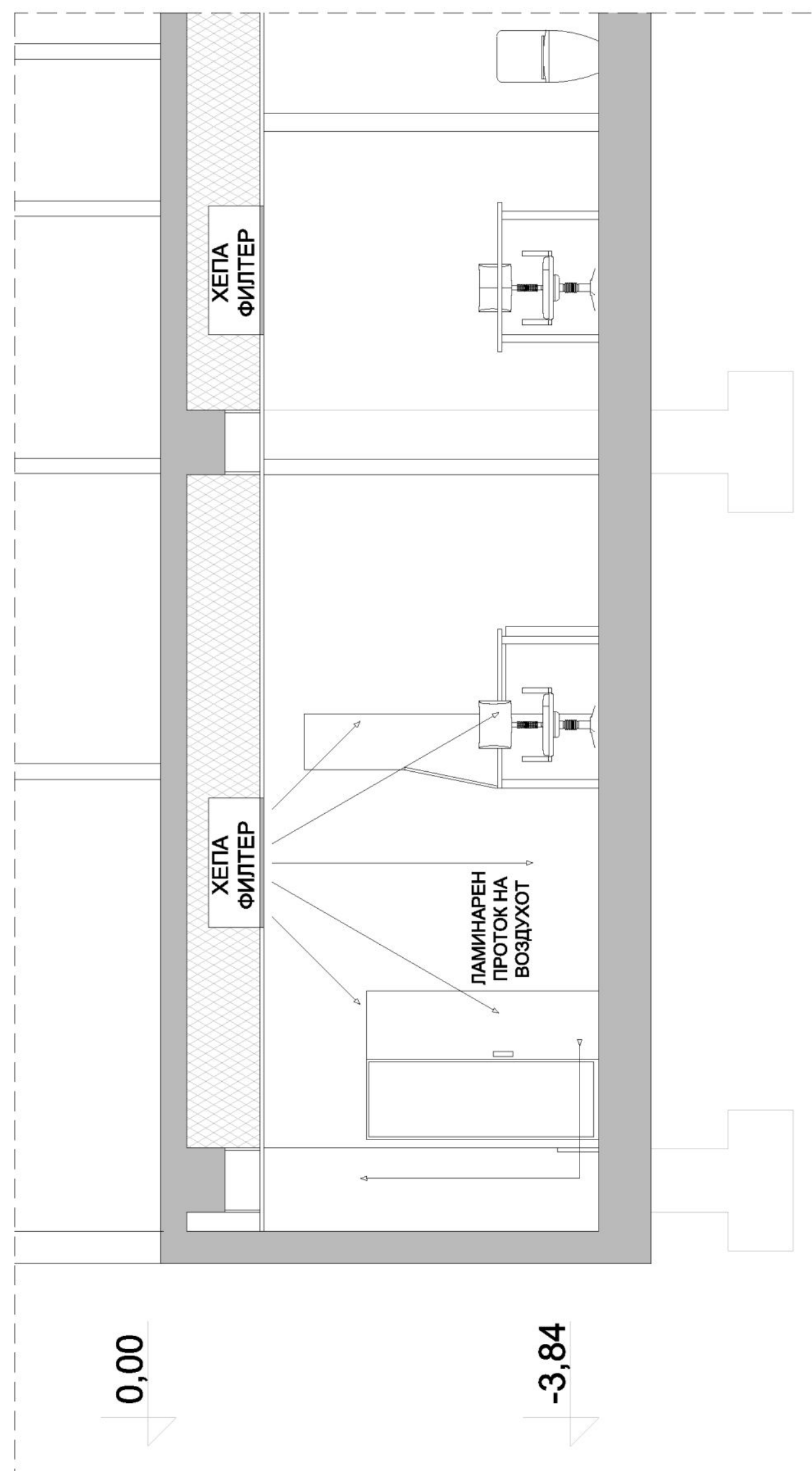

Слика 67: Ламинарен проток на позитивен воздух прочистен низ ХЕПА филтер 
6.4.1. Таванско решение и осветлување на просторот за банка за матични клетки
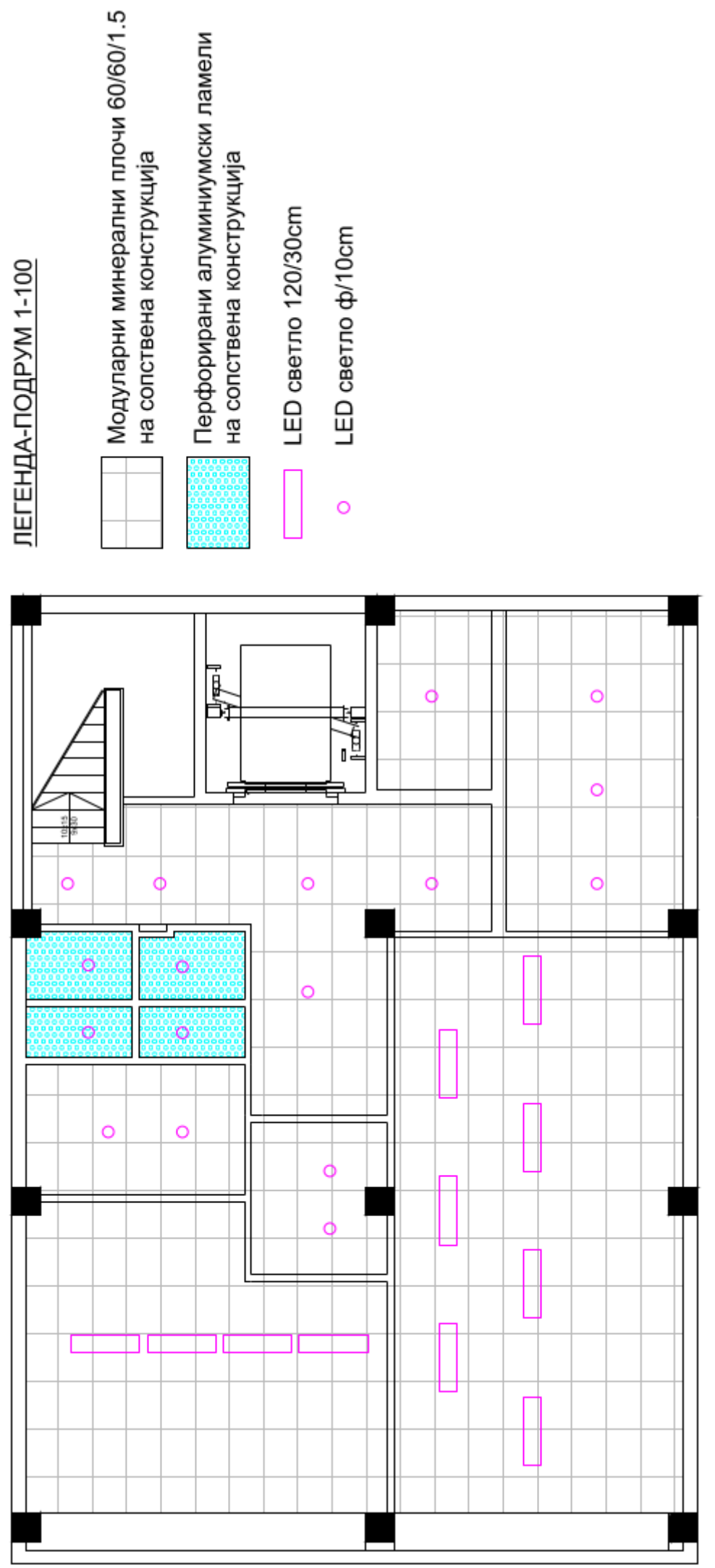

Слика 68: Шема на осветлување и плафонско решение на просторот за банка за матични клетки 
6.4.2. Таванско решение и осветлување на приземјето
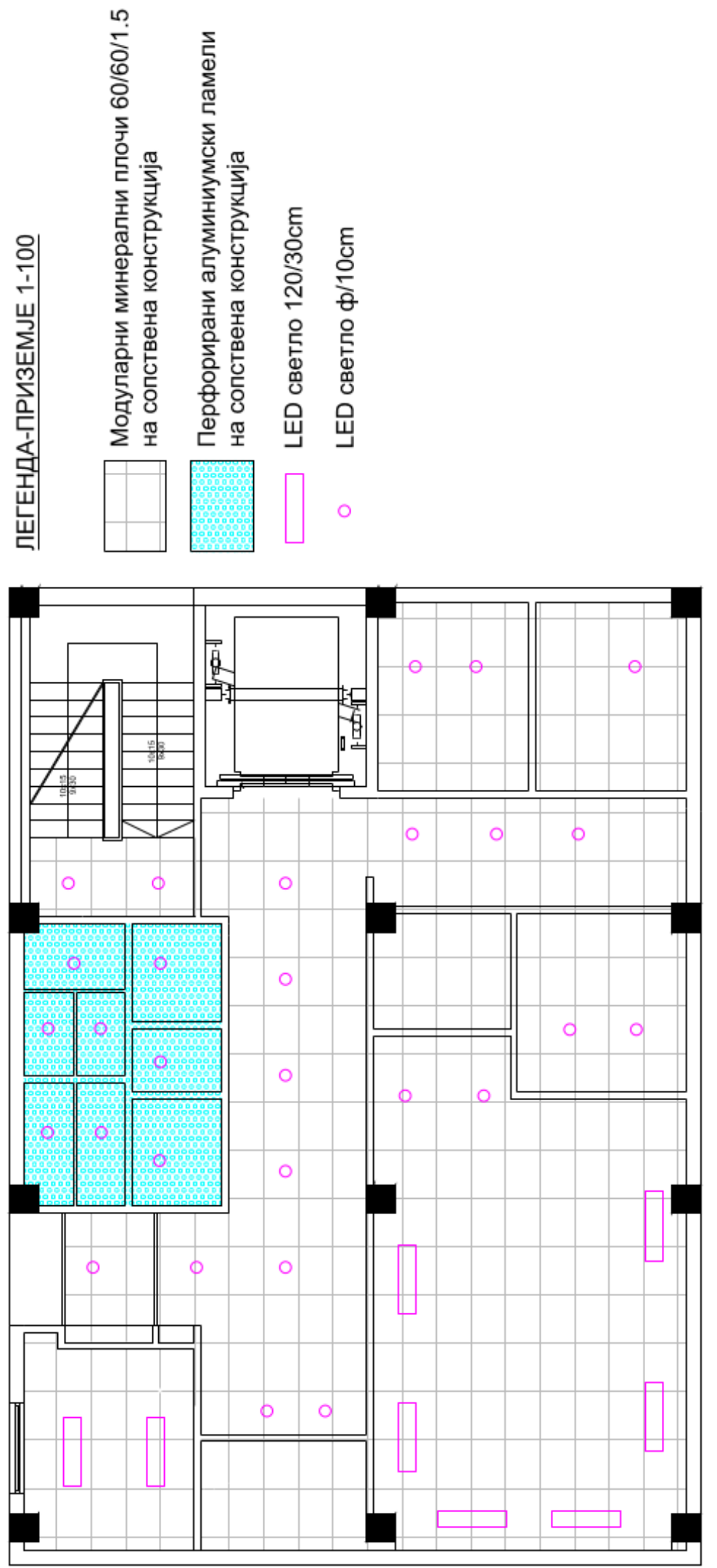

Слика 69: Шема на осветлување и плафонско решение на приземјето 
6.4.3. Таванско решение и осветлување на првиот кат
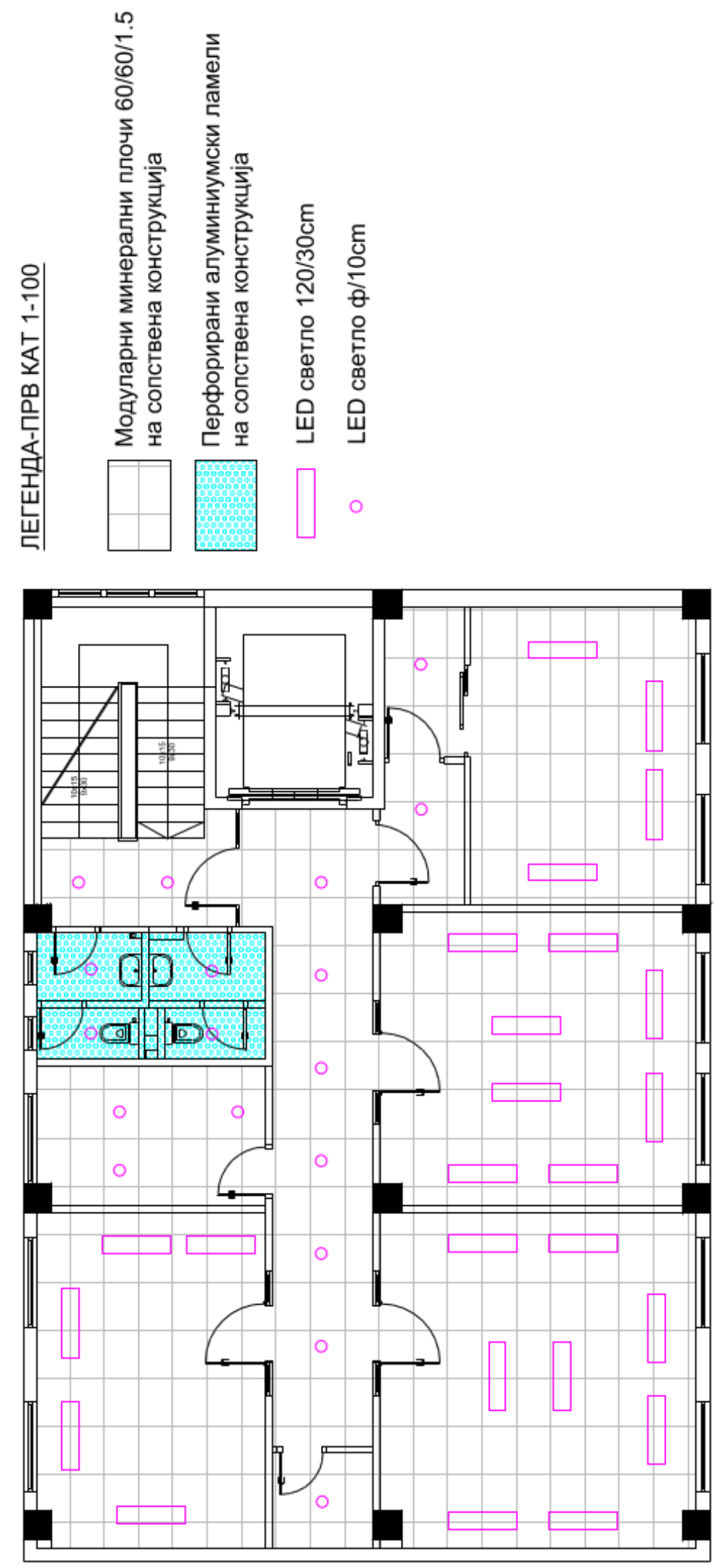

Слика 7о: Шема на осветлување и плафонско решение на првиот кат 


\section{5. Анализа на природно осветлување на лабораториите и кабинетите}

Поставеноста на објектот на североисточната страна, дозволува унилатерално природно осветлување на приземјето и катот, додека подрумот се осветлува само со вештачко осветлување.

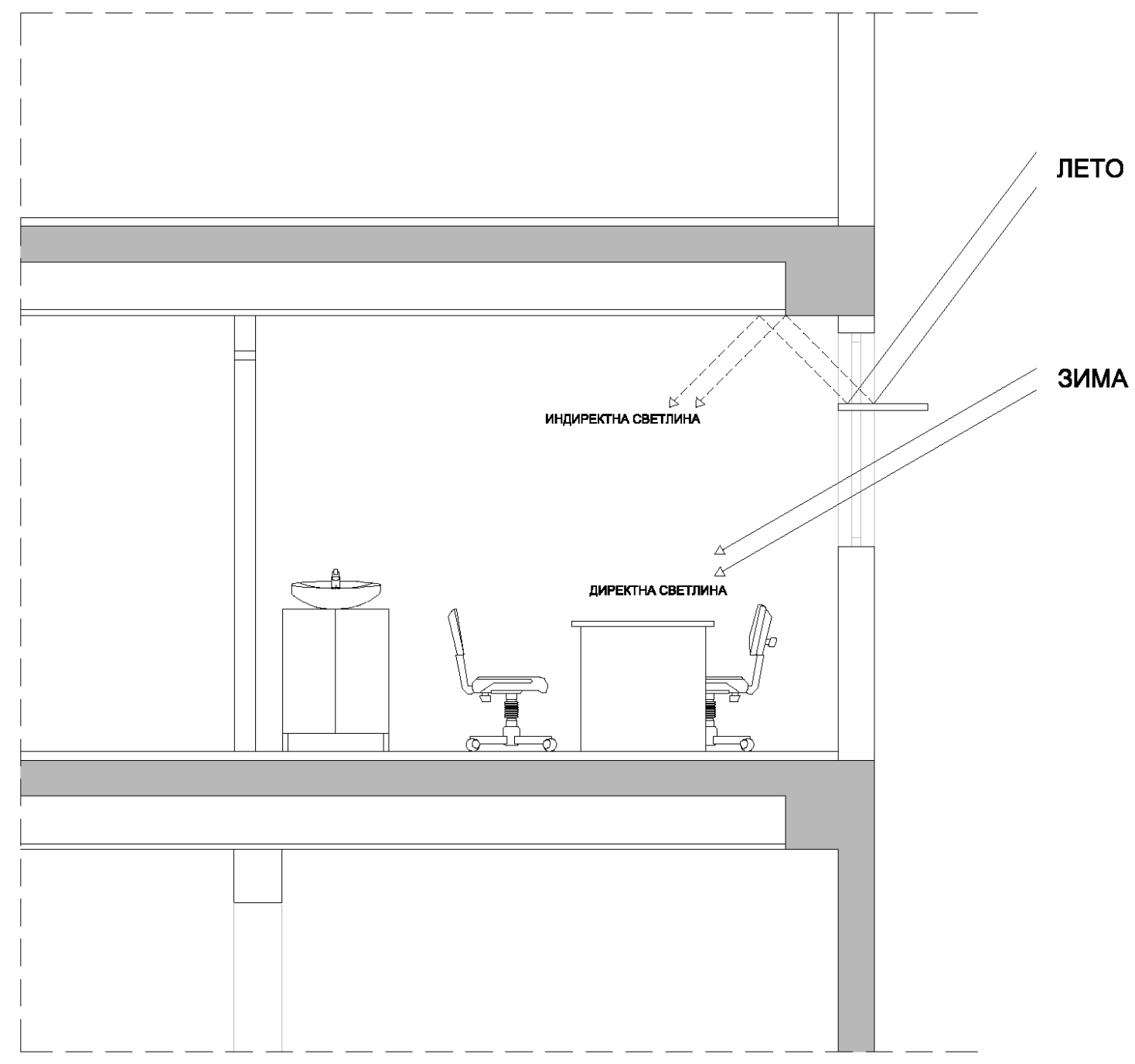

Слика 71: Природно осветлување на просторот во лето и во зима 


\section{6. Анализа на физичките карактеристики на просторот}

\subsection{1. Акустика}

Фасадните sидови и преградните sидови, како и сите облоги за топлинска заштита на хоризонтални и вертикални површини обезбедуваат заштита и од звук во рамките на пропишаните стандарди. Заштита од пренос на удари (по хоризонтала и вертикала) е обезбедена со вградување на звучно изолациски материјал во подните слоеви и ленти за одделување од вертикалните sидни површини во висина на заштитниот слој од цементен естрих, се заедно изведено како "пливачки под" на кој се нанесува завршната подна облога.

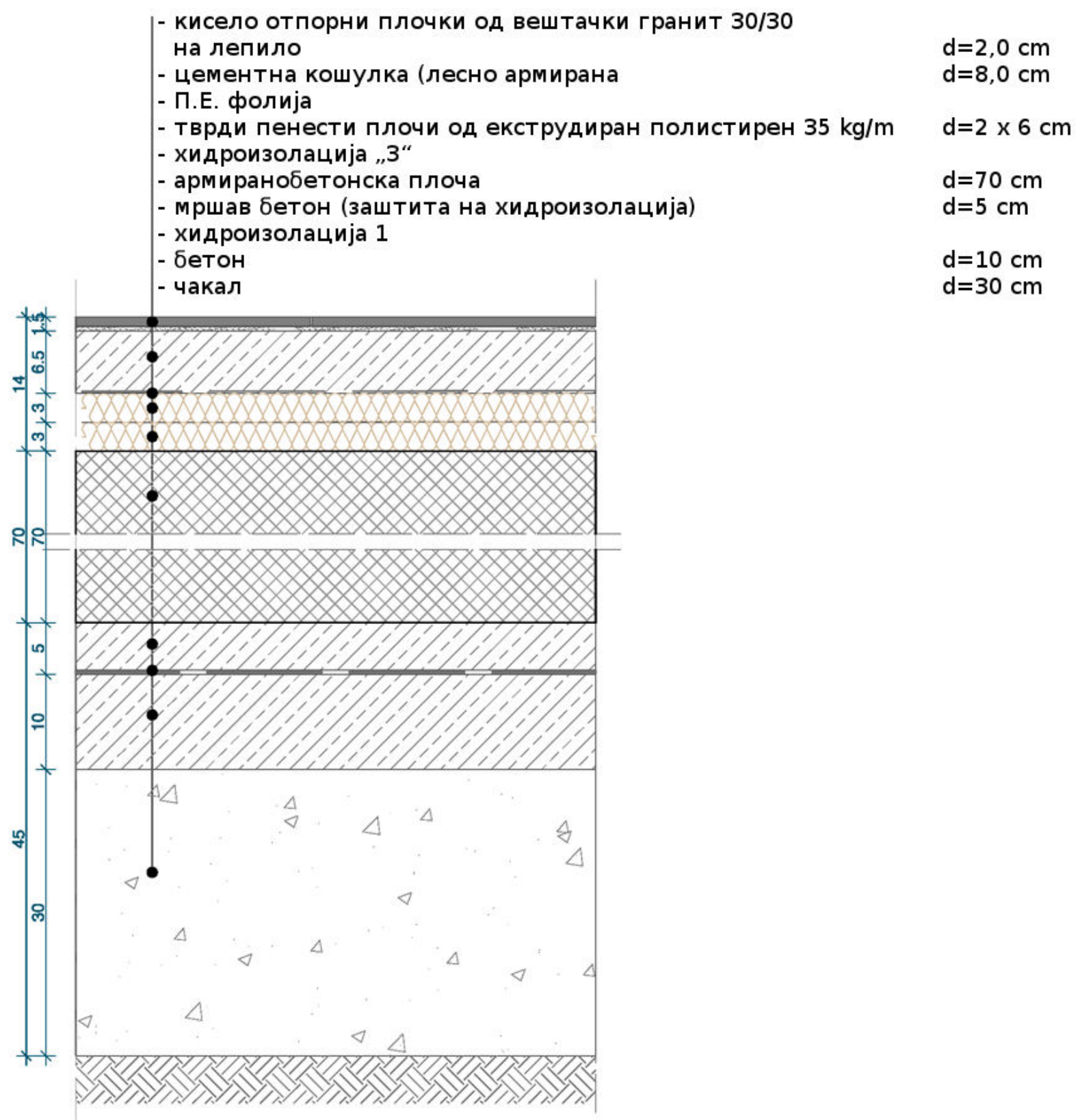

Слика 72: Детал од подот во банката за матични клетки 


\subsection{2. Загревање и ладење на објектот}

\subsubsection{1. Загревање и ладење на банката за матични клетки}
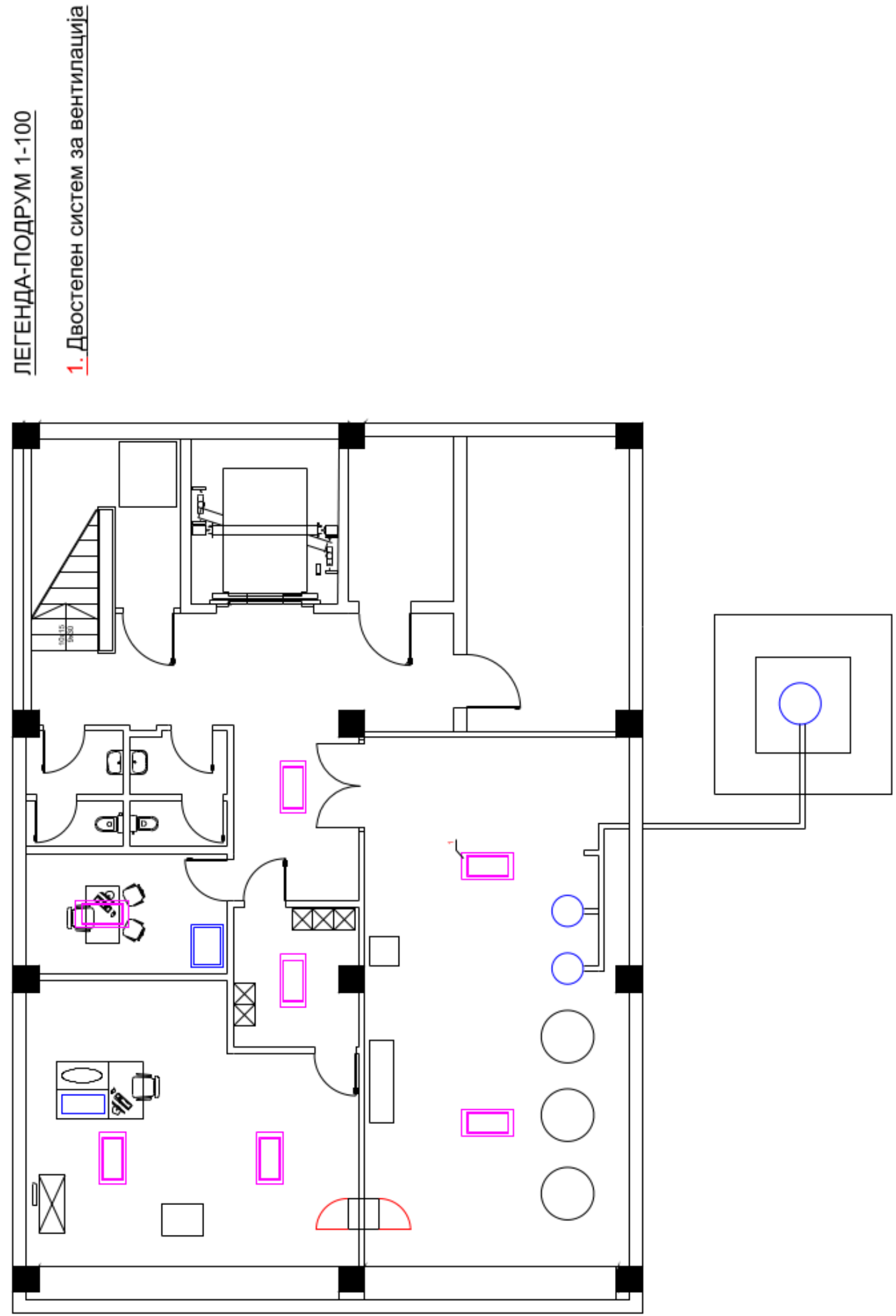

Слика 73: Шематски приказ на загревање и ладење на банката за матични клетки 
6.6.2.2. Загревање и ладење на приземјето
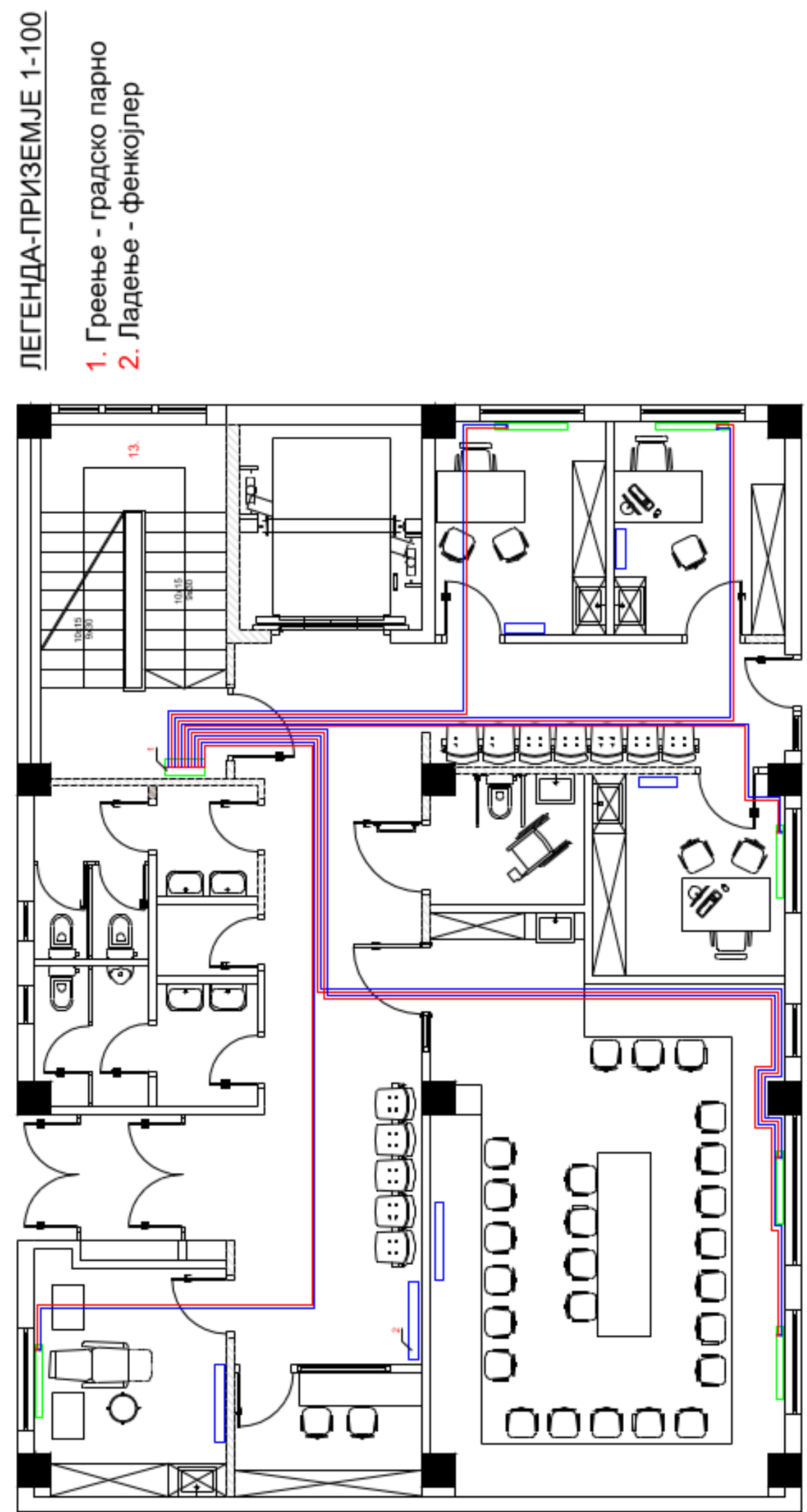

Слика 74: Шематски приказ на загревање и ладење на приземјето 


\subsubsection{3. Загревање и ладење на првиот кат}
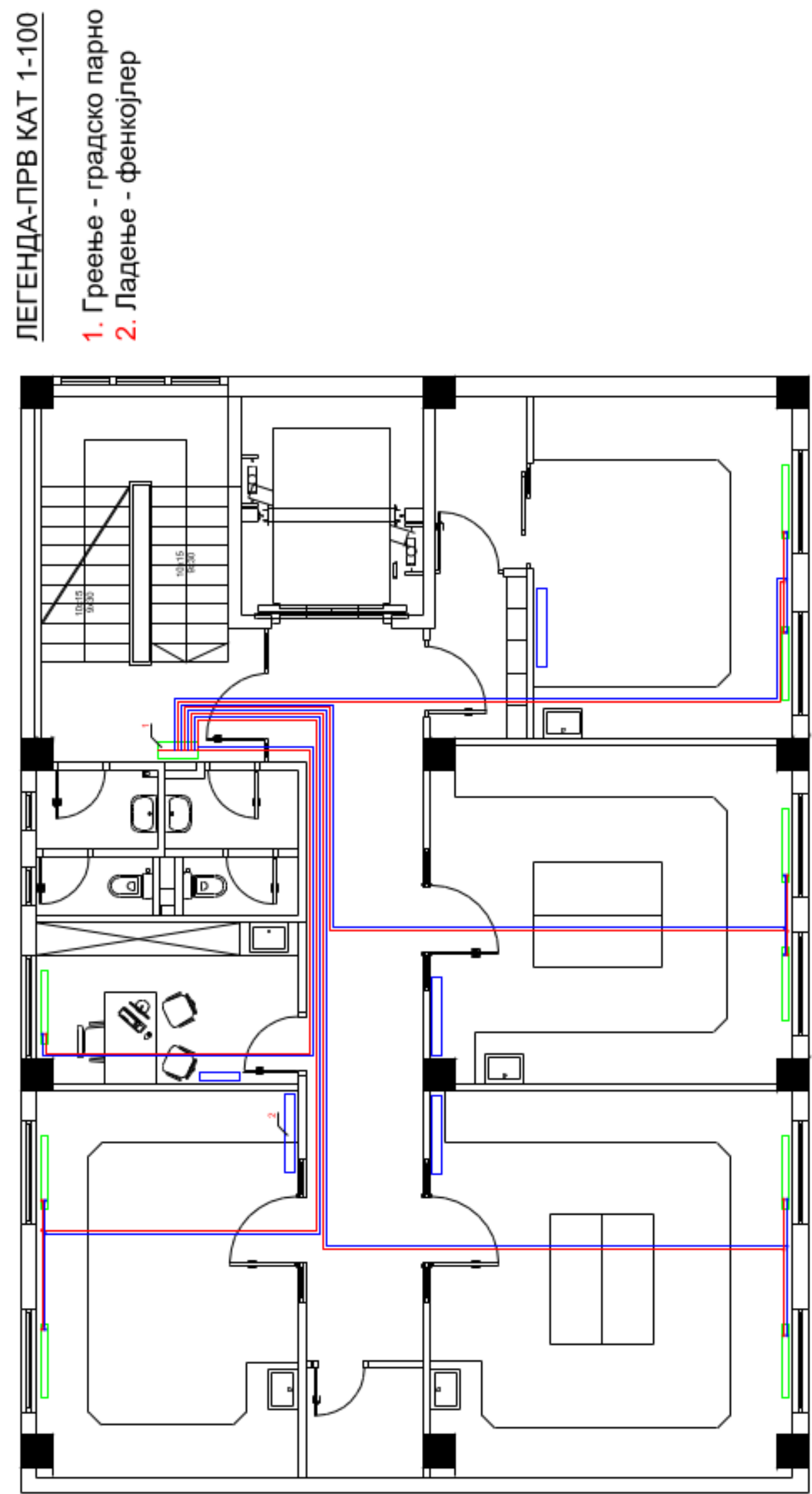

Слика 75: Шематски приказ на загревање и ладење на првиот кат 


\subsection{3. Вентилација}

Во банката за матични клетки, со цел да се осигураат услови за безбедност за корисниците, потребни се најмалку два детектори на кислород, поврзани со систем за вентилација, со следниве карактеристики:

- стандардна брзина: најмалку 10 вол/ч секогаш вклучен

- голема брзина: најмалку 25 вол/ч засилена вентилација

Секој детектор има излезен сигнал од 4-20 mA и е поврзан со специфичен уред и програмиран со два прага на аларм, во комуникација со системот за вентилација.

Доколку се надмине првиот праг, системот за аларм почнува да sвони и се активира втората брзина на системот за вентилација.

\section{7. Заклучоци}

Врз основа на анализата на хетерогените концепти при проектирање на просторите за добра производна пракса и хумана биобанка можеме да ги извлечеме следните заклучоци:

1. Идејниот проект за биобанка на матични клетки треба да се лоцира во некоја приватна или државна установа во Република Македонија. Просторот треба да биде од најмалку стоипет метри квадратни за биобанка на матични клетки. Во идејниот проект се предвидува уште додатна квадратура за економско-техничките простории и комуникацијаскали, лифт, складишен простор, хидростаница, санитарии машки, санитарии женски и ходници.

2. Анализирајќи ги состојбите во развиениот свет констатирано е дека постојат и се развиени банки за матични клетки за семејна употреба и јавно достапни банки за матични клетки. Банките за матични клетки за семејна употреба се приватни банки во која семејството складира крв од папочна врвца или изолирани матични клетки кои би можеле потенцијално да бидат употребени за некој од членовите на потесното семејство. Јавно достапните банки ги финансираат државните институции или фондации во кој брачните парови со потпишана согласност ја даруваат крвта од папочна врвца, од која се изолираат и сладираат матични клетки и се употребуваат за било кого ако е генетски идентичен. Во Република Македонија постојат поголем број на претставништва на странски банки за матични клетки од папочна врвца кои собираат примероци и ѓи испракаат во странство. Резултатите од овој магистарски труд за проектирање на банка за матични клетки би 
придонело во насока на имплементација на ова специфично проектанско барање во секојдневната медицинска пракса, во интерес на здравството.

3. Условите за производство на стерилни продукти во која се дефинирани упатства за добра производна пракса во трудот е превземено од европската пракса. Разликуваме четири степени во упатства за добра производна пракса во трудот е превземено од европската унија. Степен А е локална зона со постапки од висок ризик како на пример, полнење, затворање шишиња, отворање ампули и шишиња и правење на септички врски. Степен Б е асептичко подготвување и полнење на примероците. Степен Ц и Д се чисти простори за помалку критични постапки во подготвувањето стерилни продукти.

4. Воспоставени се технички стандарди, медицински стандарди, општествено економски стандарди за менаџирање на биобанки, информатички практики за биобанки, економски препораки за биобанки, обезбедување на квалитет на биобанки, како и специфики при проектирање и опремување на просторот за биобанки.

5. Анализираната проектна програма би можела да обезбеди насоки за изготвување на основен проект кој треба да биде изработен согласно изводот од урбанистичкиот план и важечката законска регулатива а врз основа на проектната програма на инвеститорот. Во основниот проект за банка за матични клетки се дефинирани барањата и потребите за изработка како и непречено одвивање на технолошките процеси. Решението треба да биде оптимално во однос на функцијата, конструкцијата и економичноста.

6. Техничкиот опис на потребните простории за објектот ги дефинира следните содржини: во приземјето се сместени содржините за комуникација со дарителите (чекална, простор за прием, простор за земање примероци, санитарии, соба за едукација, кабинет за молекуларна медицина и кабинет за хумана генетика). Освен тоа се предвидени и вертикални комуникации - скали и лифт. На првиот кат се предвидуваат лаборатории и кабинет за потребите на банката за матични клетки (лабораторија за проточна цитометрија, лабораторија за алергологија и серолошка имуногенетика, лабораторија за протеини и аутоантитела, лабораторија за молекуларна имунологија, кабинет за раководител на банката, остава и санитарии за вработени). Во подрумот е проектирана банка за матични клетки со потребните технички простории (банка за матични клетки, машинска просторија, хидростаница и санитарии за вработени).

7. Во секоја просторија е проектиран соодветен мебел и извршено е опремување со специфична медицинска опрема според намената на просторијата. Приземјето е опремено со административен мебел за услужување на доброволните дарители за матични клетки, како и за просторијата за земање примероци (крв, брис од уста или плунка). Прикажани се: анализа на проектот за мобилни, преградни, монтажно - демонтажни мидови, анализа на 
системско решавање на таваниците во просторот, анализа на применетото природно и вештачко осветлување, загревање и ладење на објектот.

8. Просторот за биобанка е сместен во подрум и содржи: а) GMP со три дела со позитивен притисок, од кои една лабораторија за манипулација со современи терапевтски производи, комплетирана со соблекувална и средна тампон зона; б) простор за складирање на клетки, сместен во подрум и опремен со неопходната опрема.

9. На приземјето се сместени содржините за комуникација со доброволните дарители на матични клетки: кабинет за имунологија, кабинет за молекулска медицина, кабинет за хумана генетика, просторија за едукација, просторија за земање примероци, женска бања, машка бања, како и дополнителни протории за комуникација.

10. На првиот кат се сместени содржините за обработка на примероците: лабораторија за молекуларна имунологија, лабораторија за протеини и автопротивтела, лабораторија за алаергологија и серолошка имуногенетика, лабораторија за проточна цитометрија, просторија за раководител, женска бања, машка бања, како и помошни простории.

11. Во банката за матични клетки е сместена специфична опрема: пренослив систем за броење на честици, кабинетот со ламинарен воздушен проток, bench-top центрифуга, +4/$20^{\circ} \mathrm{C}$ фрижидер - банка за крв, АХР- платформа за сепарација на матични клетки, надворешен резервоар за складирање на течен азот, Bioarchive Роботски систем, Деварови садови MVE Chart, Деварови садови BioArchive - Wessington Cryogenics PV400, систем за вентилација, систем за следливост, водена бања и вакуумска пумпа.

12. Опремата во специфичните лаборатории, сместени на првиот кат, содржат: луминометар, апарат за сортирање на клетки, автоматизиран систем за екстракција на ДНК, и систем за полимеразно верижна реакција.

Со оглед на моментите состојби, како и фактот дека во Република Македонија не постои ниту една форма на банка за матични клетки, заклучуваме дека постојат повеќе претставништва за земање и складирање матични клетки од неколку странски земји. Во интерес на Здравството и здравјето на жителите на Република Македонија пожелно би било да се проектираат, изградат и да функционираат една или повеќе банки за матични клетки организирани и конципирани на основите на европската медицинска пракса, пред се за да се покријат потребите од матични клетки за пациентите со малигни заболувања, а во иднина и за останатите намени кои овие објекти ги обезбедуваат. 


\section{8. Литература}

Andersson GBJ, Ortengren R, Nachemson A, Elfstrom G. Lumbar disc pressure and myoelectric back muscle activity during sitting. I, Studies on an experimental chair. Scandinavian Journal of Rehabilitation Medicine. 1974;3: 104-14.

Centers for Disease Control and Prevention laboratory quality assurance and standardization program. http://www.cdc.gov/labstandards/ Accessed March 9, 2012.

Comstock GW, Burke AE, Norkus EP, Gordon GB, Hoffman SC, Helzlsouer KJ. Effects of repeated freeze-thaw cycles on concentrations of cholesterol, micronutrients, and hormones in human plasma and serum. Clin Chem 2001;47:139-42.

Eiseman E, Haga SB, editors. Handbook of human tissue sources: a national resource of human tissue samples. Santa Monica, CA: RAND Corporation; 1999.

EN 301 489-7:2005

EN 301511 V9.0.2:2003

EN 50385:2002

EN 55024: 1998+A1: 2001+A2: 2003

EN 60601-1:2006

EN 60601-1-1:2001

EN 60601-1-2:2007

EN 60601-1-6:2007

EN 60601-1-8:2007

EN 61000-6-2:2001

EN ISO 7396-1:2007

EudraLex. The Rules Governing Medicinal Products in the European Union. Volume 4. EU Guidelines to Good Manufacturing Medicinal Products for Human and Veterinary Use. EUROPEAN COMMISSION ENTERPRISE AND INDUSTRY DIRECTORATE-GENERAL: Brussels, 25 November 2008.

Grandjean E. The Ergonomics of Computerized Offices. London: Taylor \& Francis, 1987.

Hatzis C, Sun H, Yao H, Hubbard RE, Meric-Bernstam F, Babiera YW, et al. Perioperative ischemia and tissue preservation effects on RNA integ239rity and microarrays of breast cancer. $\mathrm{J}$ Natl Cancer Inst 2011;103:1871-83.

Hughes S, Barnes RO, Watson PH. Biospecimen use in cancer research over two decades. Biopreserv Biobanking 2010;8:89-97. 
IEC 60304:1982(E)

IEC 60601-1-4:1996

ISBER best practices for repositories. Cell Preserv Technol 2008;6:1-58.

ISO 13485:2003

ISO 14971:2009

ISO 9001:2008

Khoury T, Sai S, Hwang J, et al. Delay to formalin fixation effect on breast biomarkers. Mod Pathol 2009;22:1457-67.

Laboratories for the 21st Century: Best Practice Guide DOE/GO-102005, August 2006.

Master Control web site. http://www.mastercontrol.com/document-control-software/ Accessed March 9, 2012.

Moore HM, Compton CC, Alper J, Vaught JB. International approaches to advancing biospecimen science. Cancer Epidemiol Biomarkers Prev 2011;20:729-32.

NCI Best Practices for biospecimen resources. Table of contents. http://biospecimens. cancer.gov/bestpractices/toc/2011 Accessed March 6, 2012.

Riegman PH, Dinjens WN, Oosterhuis JW. Biobanking for interdisciplinary clinical research. Pathobiology 2007;74:239-44.

UNI-EN-ISO 14644-1/2/3/4/5/7 regulations.

Vaught J, Caboux E, Hainaut P. International efforts to develop biospecimen best practices. Cancer Epidemiol Biomarkers Prev 2010;19:912-5.

Vaught J, Rogers J, Carolin T, Compton C. Biobankonomics: developing a sustainable business model approach for the formation of a national cancer human biobank by the National Cancer Institute. JNCI Monogr 2011;42:24-31.

Vaught JB. Blood collection, shipment, processing and storage. Cancer Epidemiol Biomarkers Prev 2006;15:1582-4. 